\title{
Story Time in Early Childhood Education: Designing storytelling activities to enhance (digital) literacy development
}


STORY TIME IN EARLY CHILDHOOD EDUCATION:

DESIGNING STORYTELLING ACTIVITIES

TO ENHANCE (DIGITAL) LITERACY DEVELOPMENT

Irena Yolanita Maureen 



\title{
STORY TIME IN EARLY CHILDHOOD EDUCATION: DESIGNING STORYTELLING ACTIVITIES TO ENHANCE (DIGITAL) LITERACY DEVELOPMENT
}

\author{
DISSERTATION
}

\author{
to obtain \\ the degree of doctor at the University of Twente, \\ on the authority of the rector magnificus, \\ prof. dr. ir. A. Veldkamp, \\ on account of the decision of the Doctorate Board, \\ to be publicly defended \\ on Friday the $15^{\text {th }}$ of January 2021 at 12:45 pm \\ by

\section{Irena Yolanita Maureen} \\ born on the $3^{\text {rd }}$ of December 1977 \\ in Surabaya, Indonesia
}


This dissertation has been approved by:

Dr. H. van der Meij

Prof. dr. A. J. M. de Jong

$\begin{array}{ll}\text { Cover design } & \text { Irena Maureen } \\ \text { Printed by } & \text { Ipskamp Printing } \\ \text { Lay-out } & \text { Sandra Schele } \\ \text { ISBN } & 978-90-365-5114-4 \\ \text { DOI } & 10.3990 / 1.9789036551144\end{array}$

(c) 2021 Irena Yolanita Maureen, The Netherlands.

All rights reserved. No parts of this thesis may be reproduced, stored in a retrieval system or transmitted in any form or by any means without permission of the author.

Alle rechten voorbehouden. Niets uit deze uitgave mag worden vermenigvuldigd, in enige vorm of op enige wijze, zonder voorafgaande schriftelijke toestemming van de auteur. 


\section{GRADUATION COMMITTEE}

Chairman/secretary Prof. dr. T.A.J. Toonen

Supervisors Dr. H. van der Meij - University of Twente

Prof. dr. A.J.M. de Jong - University of Twente

Committee members Prof. dr. A. W. Lazonder " Radboud University

Prof. dr. S.R. Ludvigsen " University of Oslo

Prof. dr. S.E. McKenney - University of Twente

Prof. dr. G.J. Westerhof - University of Twente

Prof. dr. P.C.J. Segers - Radboud University and University of Twente 
This thesis was accomplished with funding from the DIKTI scholarship - Directorate General of Higher Education, Ministry of Research, Technology and Higher Education (RISTEKDIKTI) of the Republic of Indonesia. 


\section{Acknowledgements}

Writing this thesis requires many lessons to be learned, many decisions to be made, and many obstacles to be encountered. It was not getting any easier through time, especially during the last year in the pandemic. It challenged my perseverance to the utmost level that I could ever behold. It is then with the support and encouragement of many people, I could eventually make it to the finish line.

I might not be able to thank all of them personally, but let me mention some on this page.

First of all my supervisors, Hans van der Meij and Ton de Jong. I really appreciate that you have given me the opportunity to step on the journey. Hans has been a dedicated teacher I met during my master study and short course years before, and happened to also be an inspiring mentor, thanks for numerous discussions and pep talks, for challenging my ideas when they were blurry, for being super swift in reading (and killing "my darlings"), for the encouragement, coffee, and kindness in every step - thank you for the patience you have had with me. Ton has been an infinite source of stimulating insight and challenging questions. I could always count on Ton to expose inconsistencies in my arguments, to throw new ideas whenever I was stuck with the old ones, and to keep the time on the track - thank you very much for being supportive. I've learned that doing my best is not enough; I have to finish what I am required to do. The work in this dissertation benefited enormously from both of you.

Thank you Jan Nelissen for keeping in contact with me even after I finished my master degree more than a decade ago and for assuring me that BMS UTwente is the right place for me. I walked into the BMS's "maze" building five years ago thinking that I knew what and how I want to work on. I ended up with a much more complex project that was made possible by the people I learned from and with. This dissertation grew out of the IST department, which provided me a wonderfully stimulating environment to learn in. Thank you, Sandra, for the warm welcome, for all the provided helps an international student could ask for, and also for your kind and detailed assistance for the final phase of the journey, what would I do without you. A special word of thanks goes to my bright PhD buddy, my roommate, Elise, not only could we always turn to each other for advice and questions, either on statistics, colloquiums, or anything, I respect you for enduring our Dutch \& Bahasa Indonesia lessons, my bad jokes, stories, and other nonsense almost every working day for almost four years. Thank you so much, Elise, also for always helping me with my moving from place to place and for sharing the most wonderful PhD plants - the longest I have ever taking care of. Many thanks to all proIST and ITs OWK colleagues, especially Natasha, Xiulin, Johannes, Karel, Luiza, and Sharanya - all the discussions, food, and talks really helped for an international student like me. I'm grateful to be surrounded by kind-hearted colleagues in IST, though I know most of you would love to walk into my office only for the sweet stash, haha, or a call for celebration. I've learned from you all that even a single achievement deserved celebration. 
Five years ago, I came to the Netherlands all by myself, but I know that I still have the sisterhood love from Ovie and Ipoet, my two best friends in Indonesia, who were with me from the first day and accepted me for who I am when I returned, words cannot express how grateful I am for your being. I am so thankful for meeting familiar faces, my lovely dearest old friends - Erika, Li Hua, and Mai. Thank you for being the perfect distraction when I needed one and a constant reminder of the joyfulness of being in the moment. I truly appreciate all the Indonesian updates from Damajanti - we've been through so much together, thank you for listening whenever I was down, Mbak. Thank you for the first farewell party I've ever had, Tabas groep, a wonderful group of powerful Indonesian women I am so lucky to find although in the last minutes during my stay in the Netherlands.

These years in Enschede have led me to wonderful people who become my new extended family and assisted me in taking care of my son. The lovely family of Yasir and Ojie, I couldn't thank you enough for opening your home and heart for Tristan and me. We really owe you one. Mbak Cetut, Mbak Ratna and family, Chariska, Mbak lyut and family whose souls and minds are so full of warmth, thank you for checking our family from time to time. The same word goes for all the lovely women in PPIE, Andani, Arinta, Savitri, Zakiyah, Dewi, Lusi, Mur, Siti, Nden, Sandra, Diah, Miranti, and many more.

A special tribute to my beloved parents whom I lost during this journey. Mami - your love and confidence gave me wings to fly. Thank you for making my dreams, your dreams too. I did it, mom. I finished it. You always encouraged me to aim higher, to explore more, and still to be kind and caring more than necessary. Ayah - you had been believed in me and proud of me, your little girl as you always said. I know that you two would still look out for me, my angels. I will be eternally grateful for your unconditional love.

Finally, I would like to thank my family for their immeasurable prayers, love, and support. I am blessed to have a home to return to. A perfectly imperfect big family. Thank you Wawa fams Eva, Valley, Pipiya, Rafa, lja, and Bara, and Deta and Kizz. Thank you my Ibu, Wi Oka fams - Pinky, Tj, Dwi Yoga, and Mbak Dewi fams - Mas Kris, Utri, and Utra. You've all been hand in hand taking care of my little family for me while I wasn't there and listening to my life story from time to time.

My little star, Tristan. I love you beyond the galaxy. I especially enjoy that I could do most of this journey with you by my side. You are the inspiration, the spring of all the creative storytelling ideas in all the studies, and also the very first audience of all my presentations. You gave me space when I needed to be alone and was a wonderful source of entertainment when I needed to laugh. My husband, Anom Artha, encouraged this journey from the start even knowing the demands it would place and the impact it would have on our family. I particularly appreciate your willingness to learn and grow during this phase of life with me. I sincerely thank you for being my biggest fan and such an unlimited source of encouragement and comfort. You, my love - my living diary, do know me that much.

To all who have contributed to this work, in ways both great and small, I extend my thanks. I owe its completion to each and every one of you. 


\section{Table of contents}

\section{Chapter 1: General introduction}

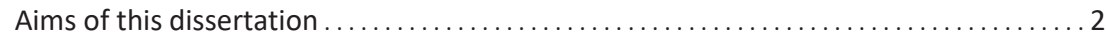

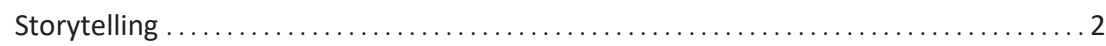

Digital storytelling ................................................... 2

Literacy and digital literacy in early childhood education ...................... 3

Early childhood education programs in Indonesia ........................ 5

Research questions ............................................ 5

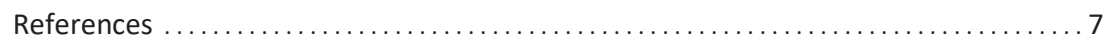

Chapter 2: Supporting literacy and digital literacy development in early childhood education using storytelling activities

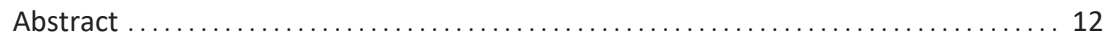

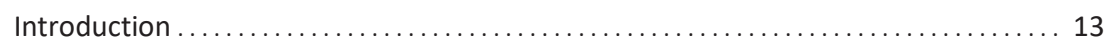

Method..................................................... 16

Results................................................ 21

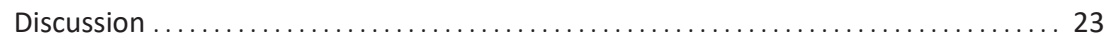

Conclusions............................................... 24

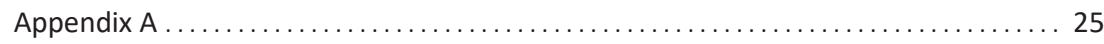

Appendix B ................................................... 26

References .................................................... 27

Chapter 3: Enhancing storytelling activities to support early (digital) literacy development in early childhood education

Abstract ................................................... 32

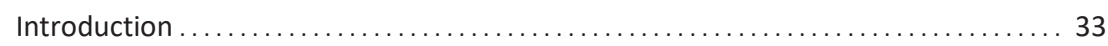

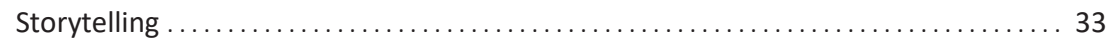

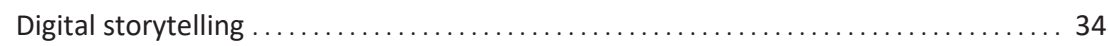

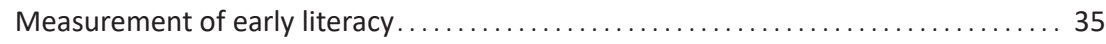

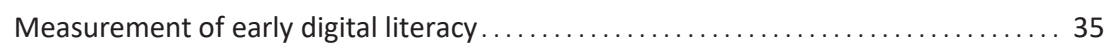

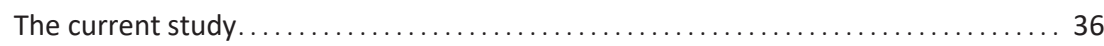

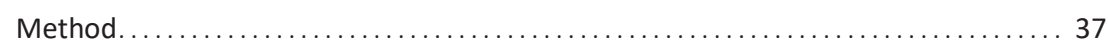

Results............................................... 42

Discussion ................................................... 44

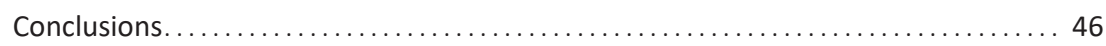

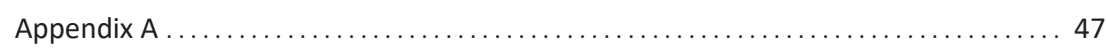

Appendix B ................................................. 48

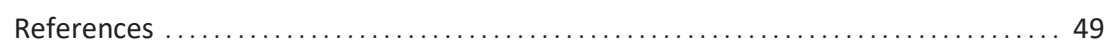


Chapter 4: Designing storytelling activities for early literacy development

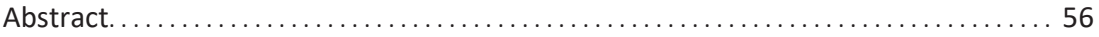

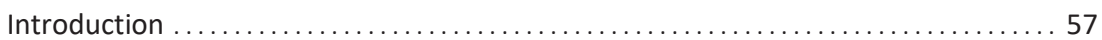

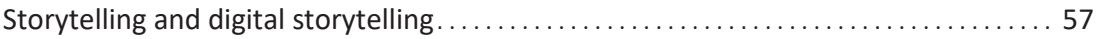

Early literacy measurements .......................................... 59

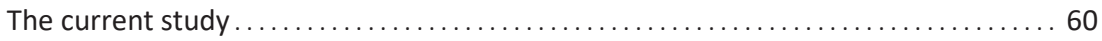

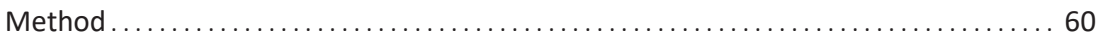

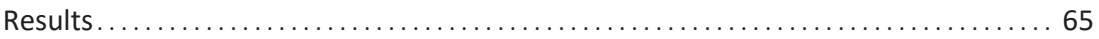

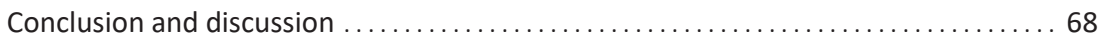

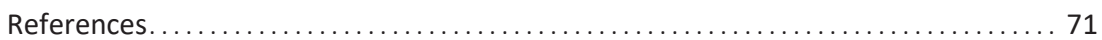

Chapter 5: General discussion

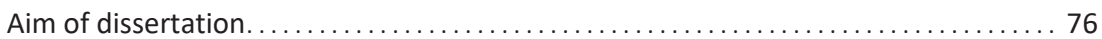

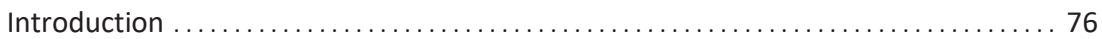

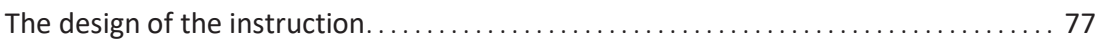

The set-up and main findings of the three empirical studies ................ 79

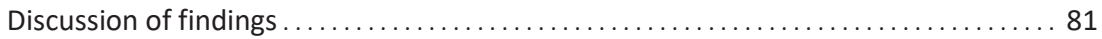

Limitations and directions for future research $\ldots \ldots \ldots \ldots \ldots \ldots \ldots \ldots \ldots \ldots \ldots$

General conclusion ......................................... 84

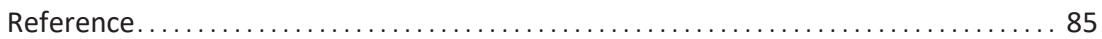

Chapter 6: English summary

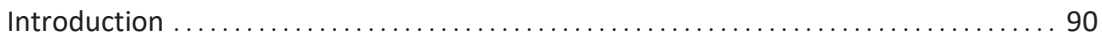

About the Studies............................................... 90

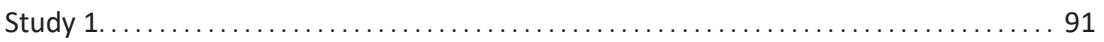

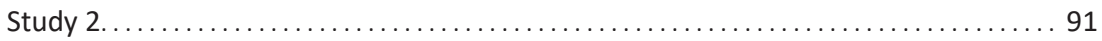

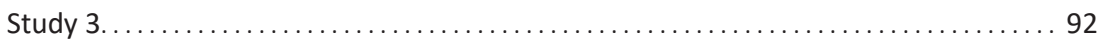

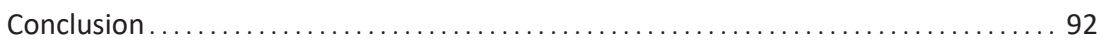

\section{Chapter 7: Nederlandse samenvatting}

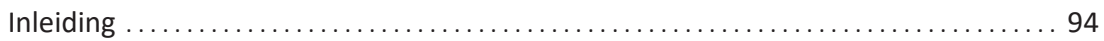

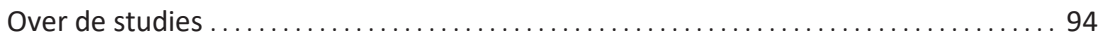

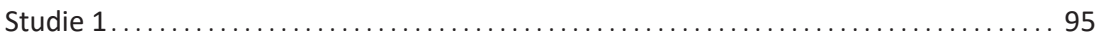

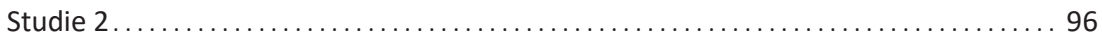

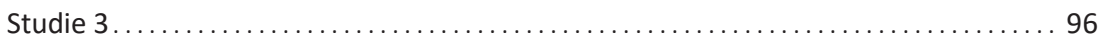

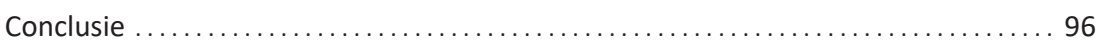




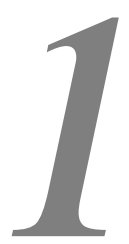

General introduction 


\section{AIMS OF THIS DISSERTATION}

This dissertation sets out to explore the design and effectiveness of an innovative approach for (digital) literacy development in early childhood education. The tested design integrated storytelling as a natural activity within a structured method, the nine events of instruction from Gagné (see Smith \& Ragan, 2005), for stimulating children's learning processes. The concept of literacy, which is the main focus in early childhood curriculum, has been steadily extending, along with the advance of technology. The curriculum for early literacy development should be responsive to these dynamic changes. This project describes how a structured storytelling approach that is integrated into the children's daily activities can enhance their literacy and their digital literacy concurrently. The next few sections briefly describe the main concepts from this thesis, more elaborate descriptions are given in the chapters in which the experiments are presented.

\section{STORYTELLING}

Storytelling is broadly defined as telling a story to others (Dudukovic et al., 2004) or more specifically using voice and gesture in conveying a narrative (Lugmayr et al., 2017). Since storytelling involves both the teller and listener(s), it involves the social aspect of language - interaction between individuals. Many research findings state that literacy development is nurtured by social interaction (Hendi \& Asmawi, 2018; Johnson, 2003), especially due to the nature of children's learning through observing others - modeling. Voice is the verbal aspect in storytelling, it makes thoughts observable through a verbal representation of actions gesture is the non verbal aspect that gains and holds the attention and provides context. Storytelling then is a way to provide a model to be observed. That is why it appears to be well-suited for using storytelling to support early literacy development in early childhood education.

The known impact of storytelling on literacy development has made it a favored single session approach in early education classrooms. It is considered a playful way to communicate with children and also an interesting and engaging method for teaching. Storytelling is usually done by reading story books, telling stories with picture books or puppets (Kocaman-Karoglu, 2015). Thus, the common approach to storytelling is that it involves a relatively loosely structured form of teaching. To further explore the possibilities of benefiting more from using storytelling in early literacy development, the present thesis systematically investigates the advantages of making storytelling more structured and integrating it into the whole set of instructions or activities.

\section{DIGITAL STORYTELLING}

Digital storytelling is a way of telling a story using multimedia - images, text, and audio (Robin, 2006). The new media technologies are considered supportive in bringing stories to life and have become an increasingly significant part of the early classroom activities. With the advantage of new digital applications and accessible equipment such as mobile phones with good digital cameras and sound recorders, it becomes easier to make, store, and share stories (Churchill, 
2016). Digital stories may include engaging images, emotionally colored narrative and sound, and the storyteller's own voice to convey personal insights. The usually short duration (between three to five minutes), the personal angle of the narrative, and the digital components - all conspire to generate children's interest and learning motivation (Liu et al., 2018) and facilitate their understanding of the content of the story (Smeda et al., 2014).

The main common research focus in digital storytelling in early childhood education is how it can serve as a basis for a formal introduction to the use of Information and Communication Technology (ICT) in learning (Yuksel et al., 2011). Although many children nowadays grow up in a digital environment, this does not automatically mean that they become digital natives (Helsper \& Eynon, 2010). Considering how storytelling is an advantage for early digital literacy development, investigating the relationship of digital storytelling to literacy development in early childhood education is therefore prospective.

\section{LITERACY AND DIGITAL LITERACY IN EARLY CHILDHOOD EDUCATION}

Literacy development in early childhood education concentrates on forming reading and writing concepts and skills (Roskos et al., 2003). There are many studies identifying skills that have a clear and consistently strong relationship with later conventional literacy skills, such as oral reading, reading comprehension, and writing. Studies agree that children can become aware of systematic patterns of sounds in spoken language, recognize words and break them apart into smaller units, learn the relationships between sounds and letters, and build their oral language and vocabulary skills - known as alphabet knowledge, phonological awareness, and print awareness. These are some of the skills found to be the strongest precursors to reading and writing (Shanahan \& Lonigan, 2010) or stated as the early literacy skills. Figure 1 presents an overview of these early literacy skills and how they precede later literacy skills.

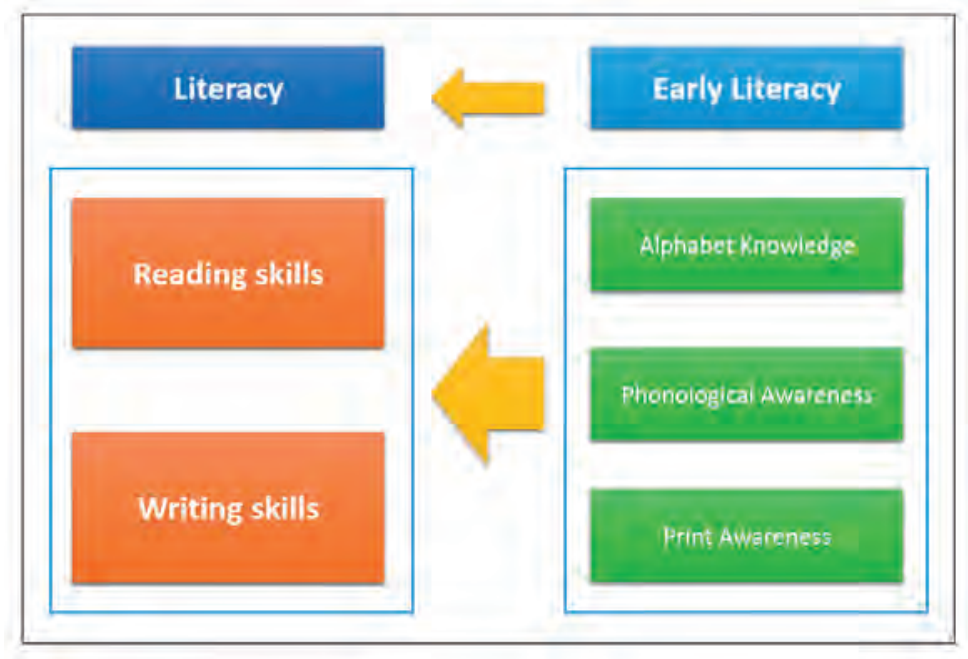

Figure 1. The relation between early and later literacy skills. 
In addition to conventional literacy, to be literate in this second decade of the 21-st century requires developing a range of digital skills and knowledge, even for children (Leu et al., 2017; Moyles et al., 2011). Some children have routinely encountered digital media and lived in a world full of digital media (Wohlwend \& Rowsell, 2016). Literacy in digital perspective follows from the print-centric notion of concepts about print (Deford, 2010) and recognizes the budding digital behaviors of young children as well as the conceptual aspects of digital technology. The increasing role of digital technology in children's daily experiences is hardly acknowledged in traditional literacy, however, which prompts the need for a broader scope of literacy. Children need to understand how to live and learn in the digital world. It includes the understanding of how to use the technology (technical skills) as well as how to be kind and smart when using the technology (Friesem, 2016).

This thesis believes that digital literacy encompasses more than a list of skills associated with operating technology; it also includes a mindset to negotiate meaning from a variety of digital contexts and use of a variety of digital devices. It aligns with the three dimensions of digital literacy: technical, cognitive, and socio-emotional skills proposed by Ng (2015). Nevertheless, there is little research related to the cognitive or socio-emotional dimensions of digital literacy in early childhood education. In the current research, we did not assess technical skills development because we wanted to stay away from their highly specific facets and investigate more the general cognitive and socio-emotional dimensions. Our research, therefore, puts most efforts into tracing the precursor skills for these two dimensions (cognitive and socio-emotional) of digital literacy, since both are also important for developing (early) digital literacy. This choice is also in agreement with the view that early digital literacy understanding includes digital and non-digital practices in using different digital technologies (Sefton-Green et al., 2017). The cognitive skills dimension of digital literacy includes critical thinking and multimodality, which means that communication and representation is more than just language usage. The socio-emotional skills dimension includes communicative and social skills. Figure 2 depicts how early digital literacy skills precede later digital literacy.

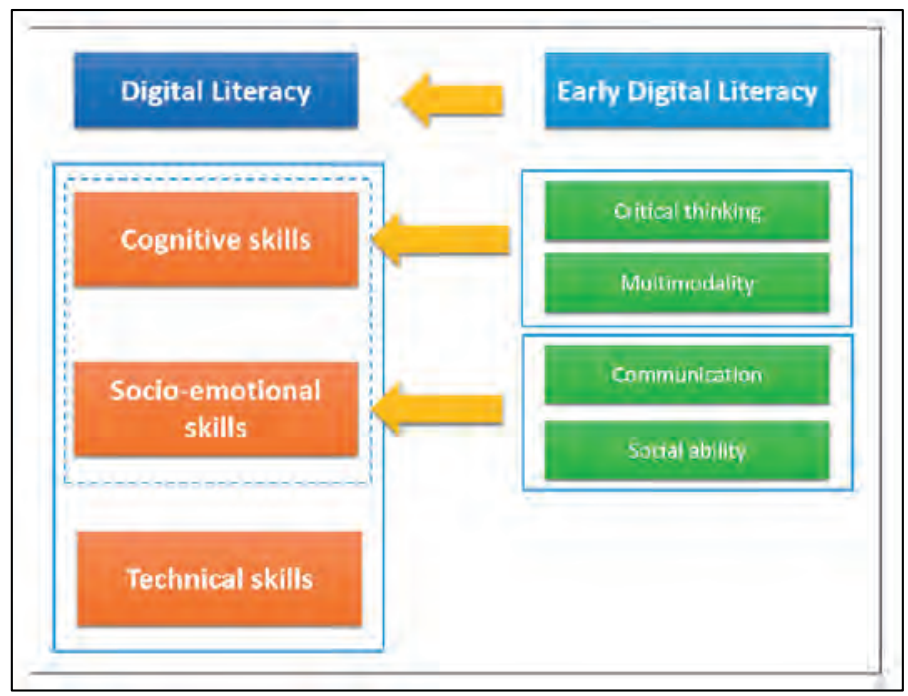

Figure 2. The relation between early literacy dimensions and later digital literacy. 


\section{EARLY CHILDHOOD EDUCATION PROGRAMS IN INDONESIA}

Recognition of the importance of early childhood education in Indonesia has increased. This development appears to rest on two arguments. The first is that it is acknowledged that early childhood education is the foundation for formal school education (which starts when children reach the age of seven year old and start elementary school). The Indonesian government recognizes that a lack of school readiness in young children affects their adaptation and academic performance in elementary school and may even affect their life-long education. The second is an increasing awareness that early childhood education should satisfy high standards to keep level with the improved living standard of the country.

Early childhood education in Indonesia is roughly divided into formal and non-formal education. Formal education aims for children aged between 4 and 6 and provides educational services for general kindergartens. Non-formal education provides educational services for playgroups (for children aged between 3 and 6) and in child care centers for children aged between 0 and 6 . Besides preparing the children for formal elementary school education, early childhood education also aims to broadly support the children's growth and development.

In this dissertation, the main focus is on formal early childhood education in general kindergartens. The suggested duration of activities in such a kindergarten is a total of 900 minutes per-week or 3 hours per-day including breaks and caring sessions (Monday to Friday). The early childhood curriculum distinguishes between four main competencies (spiritual, social, knowledge, and skills) in six development areas namely religions and moral, motoric, cognitive, language, socioemotional, and art. Early literacy is one of the main goals in two competencies (knowledge and skills) nurturing pre-reading and pre-writing abilities.

In early childhood education classrooms, the most common activity to achieve literacy goals is through reading and writing practices using formalized methods of instruction. While this formalized instruction is considered effective and practical, the long term effect and accomplishment is being questioned (Marcon, 2002). Furthermore, though traditional literacy skills are still prevalent, technological developments call for significant changes in developing literacy. If this challenge is taken on, the choice mostly falls on the technical aspect of digital literacy. Nevertheless, there is still a general lack of progress with regard to the broader scope of literacy. Most research published in the national journals for the past three years limited the early literacy goals to the ability to read and write (e.g. Astuti et al., 2016; Christianti, 2017) even when digital technology is involved (e.g. Rakimahwati \& Ardi, 2019; Sari et al., 2017). Both accounts led us to develop and test an approach that supports greater child engagement in the learning processes and a broader literacy development.

\section{RESEARCH QUESTIONS}

In early childhood education, storytelling is often related to literacy development. Digital storytelling is, then, often related to the introduction of digital literacy in early childhood education (Arslan et al., 2016; Robin, 2008). This dissertation focuses not only on (1) how 
storytelling is related to literacy; (2) or digital storytelling to digital literacy development; but also (3) whether storytelling can enhance digital literacy development and (4) whether digital storytelling can enhance literacy development. The last two questions have not yet been explored in the literature. Figure 3 displays the research questions in this thesis in a graphical form.

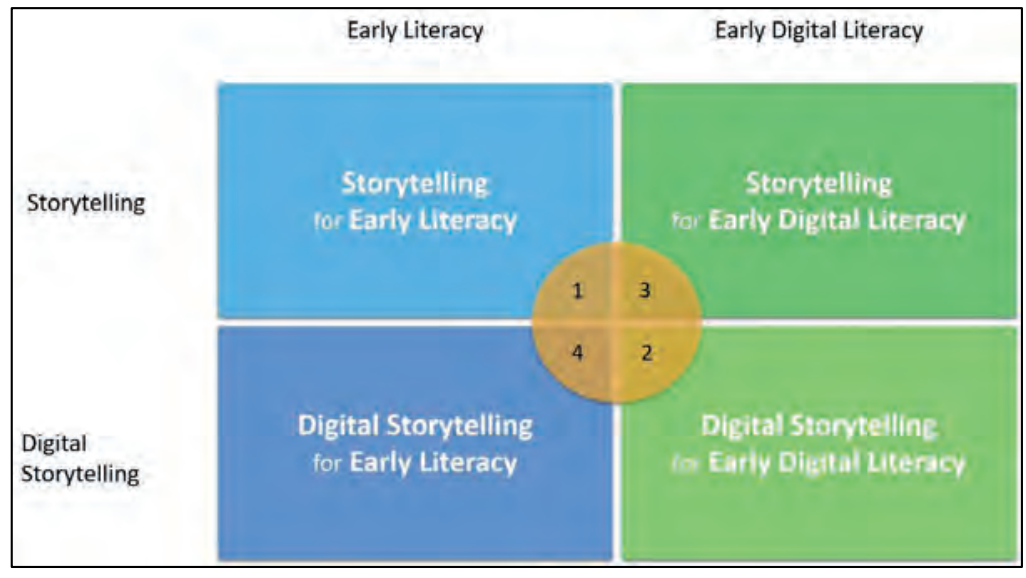

Figure 3. The research questions from this thesis.

These research questions find their way in this thesis in the following way. In Chapter 2 we investigated whether the initial design of storytelling activities, traditional and digital, would increase children's literacy development (RQ $1 \& 4)$. This study also explored the possibility of the effect on digital literacy development (RQ 2 \& 3). In Chapter 3 - all four research questions were involved, and we compared early literacy development and early digital literacy development in three different groups with specific conditions related to traditional and digital storytelling activities (RQ 1, 2, 3, 4). In Chapter 4 the set-up from Chapter 3 was repeated and measurements were extended with standardized tests for early literacy (RQ 1 \& 4). Finally, in Chapter 5 all results are summarized, critically reviewed and put into perspective. 


\section{REFERENCES}

Arslan, P., Yildirim, S., \& Robin, B. (2016). A phenomenological study: Teachers' experiences of using digital storytelling in early childhood education. Educational Studies, 1-19. https://doi.org/10.1080/03055698.2016.1195717

Astuti, T. P., Listiara, A., \& Ariati, J. (2016). Promoting emergent literacy development on Early Childhood: A case study in Indonesian families. Proceeding of 3rd International Conference on Early Childhood Education (ICECE 2016). https://doi.org/10.2991/icece16.2017.12

Christianti, M. (2017). Children's knowledge of the letter as the beginning of literacy in Yogyakarta. Indonesian Journal of Early Childhood Education Studies, 6(1). https://doi.org/10.15294/IJECES.V6I1.15784

Churchill, N. (2016). Digital storytelling as a means of supporting digital literacy learning in an upper-primary-school English language classroom. Edith Cowan University. https://ro.ecu.edu.au/theses/1774

Deford, D. (2010). Marie Clay: Changing the face of assessment. Journal of Reading Recovery, 2, 1-10.

http://digital.watkinsprinting.com/publication/?i=38776\&article_id=401561\&view=artic leBrowser\&ver=html5

Dudukovic, N. M., Marsh, E. J., \& Tversky, B. (2004). Telling a story or telling it straight: The effects of entertaining versus accurate retellings on memory. Applied Cognitive Psychology, 18, 125-143. https://doi.org/10.1002/acp.953

Friesem, Y. (2016). Chapter 2 - Empathy for the digital age: Using video production to enhance social, emotional, and cognitive skills. In S. Y. Tettegah, \& D. L. Espelage (Eds.), Emotions, technology, and behaviors (pp. 21-45). Academic Press. https://doi.org/10.1016/B978-0-12801873-6.00002-9

Helsper, E. J., \& Eynon, R. (2010). Digital natives: Where is the evidence? British Educational Research Journal, 36(3), 503-520. https://doi.org/10.1080/01411920902989227

Hendi, N. S., \& Asmawi, A. (2018). Preschool English teachers' practices and early literacy instruction: Montessori vs. international preschool curriculum. MOJES: Malaysian Online Journal of Educational Sciences, (2), 29-36. https://mojes.um.edu.my/article/view/12443

Johnson, D. (2003). The role of child development and social interaction in the selection of children's literature to promote literacy acquisition. Early Childhood Research \& Practice, 5. https://www.ecrp.illinois.edu/v5n2/johnson.html

Kocaman-Karoglu, A. (2015). Telling stories digitally: An experiment with preschool children. Educational Media International, 52(4), 340-352. https://doi.org/10.1080/09523987.2015.1100391 
Leu, D., Kinzer, C., Coiro, J., Castek, J., \& Henry, L. (2017). New literacies: A dual-level theory of the changing nature of literacy, instruction, and assessment. Journal of Education, 197, 1-18. https://doi.org/10.1177/002205741719700202

Liu, K.P., Tai, S.J. D., \& Liu, C.C. (2018). Enhancing language learning through creation: The effect of digital storytelling on student learning motivation and performance in a school English course. Educational Technology Research and Development, 66. https://doi.org/10.1007/s11423-018-9592-z

Lugmayr, A., Sutinen, E., Suhonen, J., Islas Sedano, C., Hlavacs, H., \& Suero Montero, C. (2017). Serious storytelling - a first definition and review. Multimedia Tools and Applications, 76, 15707-15733. https://doi.org/10.1007/s11042-016-3865-5

Marcon, R. (2002). Moving up the grades: Relationship between preschool model and later school success. Early Childhood Research \& Practice, 4. https://ecrp.illinois.edu/v4n1/marcon.html

Moyles, J., Georgeson, J., \& Payler, J. (2011). Beginning teaching, beginning learning: In early years and primary education. McGraw-Hill Education. https://books.google.co.id/books?id=EKleqQ9XiYEC

$\mathrm{Ng}, \mathrm{W}$. (2015). Digital literacy: The overarching element for successful technology integration. In W. Ng, New digital technology in education. Springer. https://doi.org/10.1007/978-3-31905822-1_6

Rakimahwati, R., \& Ardi, Z. (2019). An alternative strategy for increasing Indonesian student digital literacy skills through interactive game. Journal of Physics: Conference Series, 1339, 012122. https://doi.org/10.1088/1742-6596/1339/1/012122

Robin, B. (2006, March 6). The educational uses of digital storytelling. Society for Information Technology \& Teacher Education International Conference 2006, Orlando, Florida, USA. https://www.learntechlib.org/p/22129

Robin, B. (2008). Digital storytelling: A powerful technology tool for the 21st century classroom. Theory Into Practice, 47, 220-228. https://doi.org/10.1080/00405840802153916

Roskos, K., Christie, J., Richgels, D., \& Dickens, C. (2003). The Essentials of early literacy instruction. Young Children, 58(2), 52-60. https://www.bowdoin.edu/childrenscenter/pdf/literacy-essentials.pdf

Sari, D. K., Handayani, S., \& Tasuah, N. (2017). Application of media booklet to improve language development (initial reading) on children in kindergarten Kemala Group B Bhayangkari 34 Kendal, 6(2). https://doi.org/10.15294/IJECES.V6I2.20242

Sefton-Green, J., Marsh, J., Erstad, O., \& Flewitt, R. (2017). Establishing a research agenda for the digital literacy practices of young children: A white paper for COST action IS1410. https://doi.org/10.13140/RG.2.2.10896.30720

Shanahan, T., \& Lonigan, C. (2010). The national early literacy panel: A summary of the process and the report. Educational Researcher, 39, 279-285.

https://doi.org/10.3102/0013189X10369172 
Smeda, N., Dakich, E., \& Sharda, N. (2014). The effectiveness of digital storytelling in the classrooms: A comprehensive study. Smart Learning Environments, 1(1), 6. https://doi.org/10.1186/s40561-014-0006-3

Smith, P. L., \& Ragan, T. J. (2005). Instructional design (3rd ed.). Wiley.

Wohlwend, K., \& Rowsell, J. (2016). Free play or tight spaces? Mapping participatory literacies in apps. The Reading Teacher, 70(2), 197-205. https://doi.org/10.1002/trtr.1490

Yuksel, P., Robin, B., \& McNeil, S. (2011, March 7). Educational uses of digital storytelling all around the world. Society for Information Technology \& Teacher Education International Conference 2011, Nashville, Tennessee, USA.

https://www.learntechlib.org/p/36461 


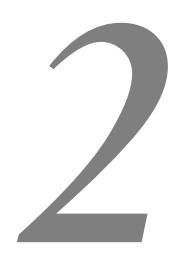

\section{Supporting literacy and digital literacy development in early childhood education using storytelling activities}




\begin{abstract}
Educators have increasingly adopted formalized approaches for teaching literacy skills in early childhood education. In line with an emergent critique of this approach, the present study investigated the design and effectiveness of a literacy intervention that blended Gagné's nine events of instructional design with storytelling. Three classes in a public preschool in Indonesia participated in an experimental study involving 45 children, aged 5 to 6 years. Across three weeks, one experimental condition received storytelling activities and a second experimental condition received digital storytelling activities. The control condition received regular literacy classroom activities. Before, and after, the three-week storytelling intervention, measures of literacy and digital literacy skills were administered to all groups. In the digital storytelling condition, children's literacy skills increased significantly compared to children in the control condition. Other exploratory data analyses suggested that both types of storytelling activities enhanced digital literacy skills. The findings need to be replicated with an extended series of storytelling activities that involve larger groups of participants.
\end{abstract}

Keywords: digital storytelling, storytelling, literacy skills, early childhood, literacy intervention, experimental design 


\section{INTRODUCTION}

Success in school is dependent, to a great extent, upon the development of skills in reading and writing gained during the early childhood years (NAEYC, 1998). The development of literacy skills should therefore be nurtured from an early age. Accordingly, an increasing number of parents and other educators now hold the opinion that a child should be able to learn to read and write in kindergarten. In response, many kindergartens have adopted formalized methods of instruction for teaching literacy. However, this approach has left little room for young children's natural and playful way of learning (Bassok et al., 2016). This has led to a call for a design approach that supports literacy development and greater child engagement in the learning processes. One response to this call is a focus on storytelling. Storytelling is a natural way of communicating with young children.

Digital technology has also become a part of most children's everyday experiences. By the time children reach kindergarten, they are likely to have had countless encounters with various digital forms of communication. Therefore, for today's young children, to be literate should also include developing a range of digital skills and knowledge. Digital literacy development has received far less attention than traditional forms of literacy. The increasing integration of digital forms of reading and writing into everyday life suggests that the role of technology for (digital) literacy development of kindergarten children is also a timely and important topic.

The main aim of the present study is to describe a series of activities to support literacy and digital literacy skills in which storytelling is infused within an instructional design framework. In addition, a set of literacy and digital literacy measures were developed to assess the effects of these activities. To our knowledge, the effort to create a series of activities that blend a more formal type of instruction with storytelling and to assess the effects on digital literacy skills in early childhood education, presents a relatively novel approach.

\section{Storytelling and digital storytelling}

Storytelling is a process in which someone (the storyteller), uses vocalization, narrative structure, and mental imagery to communicate with an audience (the listener) (Peck, 1989). The listener also uses mental imagery and communicates back to the storyteller primarily through body language and facial expressions (Roney, 1996). This interaction is repeated in multiple communication cycles during any storytelling event. Storytelling thus becomes an act of mutual meaning-making and learning by all participants (Katuscáková \& Katuscák, 2013). Storytelling supports literacy development because it allows children to also hear models about how language can be used. Storytelling can also promote writing skills by encouraging children to create their own stories, modify stories that they have heard, and even write plays based on familiar tales (Cassell, 2004; Nicolopoulou et al., 2015).

For a long time, storytelling was employed spontaneously rather than as a deliberate and planned instructional approach in early childhood education (Coskie et al., 2010; Phillips, 2013). The use of storytelling as an engaging and meaningful teaching approach in early literacy education began with the work of Kieran Egan $(1985,1986)$. Egan proposed that teaching is best shaped in story 
formats because storytelling stimulates children's imagination which is a very powerful learning tool. Agosto (2016) noted that storytelling can nurture cognitive engagement, critical thinking, and story sequencing. Her research also showed that follow-up activities such as discussion, retelling, and topic-related activities (written, drama, oral) can further enhance literacy development.

Storytelling has always been at the core of human activity (Lambert, 2010). Individuals and societies have continuously explored new ways to make stories compelling, moving, empowering, and everlasting. Recently, this has occurred by integrating Information and Communication Technologies (ICT), yielding a form of digital storytelling (Brígido-Corachán \& Gregori-Signes, 2014). Generally, digital storytelling revolves around presenting short, personal narratives (Meadows, 2003) that combine images with text, narration, voice, and music (Robin, 2008). In other words, digital storytelling offers children story content in digital, technology-based formats.

Porter (2005) explained digital storytelling as integrating the ancient art of oral storytelling with an array of technical tools to present personal tales with images, graphics, music, and sound, including the storyteller's voice. This definition resembles that of Robin (2008) and Psomos and Kordaki (2015) who characterized digital storytelling as traditional storytelling with multimedia. Similarly, Kearney (2011) describes digital storytelling as a short narrative captured in video format. Several studies with older children have shown that digital storytelling can generate children's interest and learning motivation, and facilitate their understanding of complex subject matter (Robin, 2008; Sadik, 2008).

Empirical studies on digital storytelling in early childhood education have concentrated on the teacher (e.g. Kildan \& Incikabi, 2015; Yuksel-Arslan et al., 2016). Effects of digital storytelling on children have, to our knowledge, been investigated for math or ICT, but not literacy (e.g. Preradovic et al., 2016). The relationship of digital storytelling to children's overall literacy development in early childhood education is therefore yet to be explored.

\section{Measuring literacy and digital literacy development}

Literacy is the use of social practices of creating and interpreting meaning through text (Kern, 2000). A person who focuses on text comprehension is reading to learn, and while doing so becomes literate. To be able to read to learn, children should learn to read (Robinson et al., 2013). There are considerable debates about when children should develop their reading skills and how the acquisition of literacy should manifest itself in the early years (Fletcher-Flinn, 2015).

In early literacy development, a distinction is often made between code and meaning-related skills (Lonigan et al., 2011). Code-related skills include print knowledge, alphabet knowledge, and phonological awareness, among other things (Owodally, 2015). Meaning-related skills include vocabulary, grammatical ability, and oral narrative ability (Westerveld et al., 2015). Knowledge about causes, correlates, and predictors of children's reading successes and failures in primary and secondary education, has expanded greatly in recent decades. This knowledge has led to the development of standardized and non-standardized methods of measuring literacy development in early childhood (Lonigan et al., 2011).

A common form of non-standardized methods for measuring literacy development revolves around teacher observations and related assessments such as checklists, rating scales, and portfolios of 
children's products. Since the procedures are not standardized, the demonstration of children's skills may not be uniformly measured across all children. A common critique of non-standardized methods is that teacher observations are often informal rather than well-structured, resulting in measurement of skills that only reflect the teacher's judgment of the child (Brown \& Rolfe, 2005).

A popular standardized method for literacy development assessment is the Dynamic Indicators of Basic Early Literacy Skills test (DIBELS; Kamii \& Manning, 2005). The DIBELS mainly focuses on code-related skills. It consists of the following subtests: Initial Sounds Fluency, Letter Naming Fluency, Phonemic Segmentation Fluency, Nonsense Word Fluency, and Word Use Fluency. The suitability of the DIBELS, and other standardized instruments, for measurement of early childhood literacy development, has generated considerable debate (Myers et al., 1996; National Research Council, 2000). Concerns have been voiced about time required for such assessment, distractions that interfere with accurate measurement of capabilities, and young children's limited test-taking abilities to assess competence. In view of these concerns, this study has adapted content from standardized tests to align with the directions of the local curriculum. The measurement of skills in this study focused on just three key skills of literacy development: alphabet recognition, phonological awareness and print awareness. Meaningful items were created for authenticity of the child assessments.

The increasing use of technology in children's everyday life has stimulated the emergence of digital literacy which has also been referred to as computer, technology, information, media, and communication literacies (Martin \& Grudziecki, 2006). All these terms share the view that they involve technology other than text. Throughout this paper, we use the term digital literacy to refer to the use of social practices of creating and interpreting meaning through texts with technology (e.g., Kern, 2000). According to Ng (2015), a digitally literate person is a competent user of three dimensions of digital technology: technical, cognitive, and socio-emotional. The dimension of technical skills is the most developed area of digital skills measurement. It includes knowledge of devices and operating skills with a focus on technical usage of computer (Ba et al., 2002), online abilities (Sonck et al., 2011), exploring tablets (Marsh, 2016), and operational use of digital devices (Eshet-Alkalai \& Chajut, 2009; Eshet-Alkali \& Amichai-Hamburger, 2004; Eshet, 2012). However, there is little research related to the assessment of cognitive or socio-emotional dimensions of digital literacy.

The present study considers cognitive and social-emotional skills dimensions because they are important prerequisites of digital literacy. This choice is also in line with a definition of digital literacy in early childhood education that has emphasized the use of digital and non-digital practices in using different digital technologies (Burnett et al., 2014; Sefton-Green et al., 2016). The cognitive skills dimension of digital literacy includes critical thinking and multimodality, which infers that communication and representation is more than just about language. The socialemotional skills dimension includes communicative and social skills. We did not assess technical skills development in this study because available tests are too complex for young children and we wanted to stay away from highly specific facets of technical skills and investigate more general cognitive and social-emotional dimensions. 
Measurement for both literacy and digital literacy development in the present study has taken into account two critical considerations: a focus on content and determining what should be measured, in order to be able to assess the effectiveness of designed activities; and establishing a procedure which was not time-limited in order not to put children in stressful situations.

\section{The current study}

The main research question addressed in this research is: Do oral or digital storytelling activities increase literacy and digital literacy development? In order to answer this question an experimental design was adopted that included three different conditions: a control condition with usual literacy practices implemented in one classroom, and two experimental conditions implemented in two other classrooms. One condition focused on literacy through oral storytelling and the other condition focused on digital literacy using technology-based storytelling. No differences in children's outcomes for literacy was expected between the two experimental conditions.

\section{METHOD}

\section{Participants}

The study was conducted in a public preschool in Indonesia. The study involved three classrooms that accommodated 45 children ( 25 girls and 20 boys), with an average age of 5.39 years (SD = 0.41 ). All classrooms used the same curriculum.

\section{Research design}

The research design was quasi-experimental with three conditions. Classrooms were randomly assigned to conditions: Control (C); Oral storytelling (S); and Digital storytelling (DS). In the control condition (C), the children received their regular classroom literacy enhancement activities. This condition yielded baseline data and information on maturation of literacy and digital literacy development across the time of the study. In one experimental condition, the children received oral storytelling activities (S), in which a story was read aloud and presented with some visual clues. In the other experimental condition, the children received digital storytelling activities (DS) and the children watched and listened to a recorded story.

\section{Instructional materials}

There were three storytelling sessions for each of the experimental conditions. The theme for the three storytelling sessions was "Me". This is a common theme for classroom activities at the beginning of the school year. The sessions focused on "My Name", "My Birthday", and "My Hobby". The content of sessions had an identical storyline across the experimental conditions. The didactic approach in each activity session followed Gagné's events of instructional design (Smith \& Ragan, 2005). For example, the theme of the first activity was "My name" (See Table 1). The main objective was to enhance the children's understanding of their own identity as presented in oral and printed form. More specifically, the activities supported the development 
of the recognition of letters and the sounds associated with letters in children's full name and nickname. The storyline revolves around a boy who likes his name, recognizes his name written on his belongings, and also recognizes the sounds of his name.

Table 1

Gagné's events of instruction for the activities focused on the theme, "My name"

\section{Gagné's events}

of instruction

\section{Classroom Sessions}

1. Gain attention

Circle time, opening (30 minutes)

2. Inform learners

- Engagement in morning routines of the objectives

- Teacher tells the children about the topic and objective of the

3. Stimulate recall lesson of prior learning

- Sing the alphabet song and tracing one's own name in empty name-cards

4. Present the content

5. Provide learning guidance
(Digital) Storytelling session (30 minutes)

- The storytelling session starts with stating the rules.

- Teacher tells the title of the story.

- Teacher tells the story (or plays the digital story).

- Teacher leads a discussion about the character and the story.

6. Elicit performance

7. Provide feedback

Follow up activities (60 minutes)

- Create a book label: children search for the letters that make up their name and arrange the letters to form the name.

- Play a game in which children exchange name cards with their friends.

- Teacher interacts with children to provide support and feedback.

8. Assess performance

9. Enhance retention and transfer
Circle time, closure (30 minutes)

- Each child colors a magic post card so that it reveals the hidden name.

- Children show and read each post card.

- Teacher reviews the story and summarizes activities for (digital) storytelling activities.

\section{Assessment instruments}

\section{Literacy measures}

The literacy measures assessed three core skills of early reading and writing, namely alphabet knowledge, phonological awareness, and print awareness. Alphabet knowledge and phonological awareness play different roles in literacy acquisition and development. These two sets of knowledge are both necessary for the acquisition of literacy (Muter, 1994). The same literacy measures were used before and after the children had participated in the three intervention activities.

Alphabet knowledge is one important aspects in the acquisition of literacy during the early childhood years (Foulin, 2005; Wood \& McLemore, 2001). It is defined as the ability to name, distinguish shapes, write, and identify the sounds of the alphabet (Piasta \& Wagner, 2010). 
Phonological awareness is another important skill linked to the acquisition and development of reading skills in school (McLachlan \& Arrow, 2010). It is an awareness of sounds in spoken words that is revealed by abilities such as rhyming, matching initial consonants, and counting the number of phonemes in spoken words. Phonological awareness has been measured, and consequently defined, by many different tasks. One of them is isolating single sounds from words (Murray et al., 1996).

Print awareness refers to children's ability to recognize the function and form of print and the relationship between oral and written language (Pullen \& Justice, 2003). Important reading prerequisites include children's ability to recognize environmentally embedded and contextualized print, to understand the form and function of print, and to perceive the relationship between speech and print (Kassow, 2006). In their study, Justice and Ezel (2001) highlight the importance of measuring this ability by using storybooks in order to provide a meaningful context for the words.

\section{Literacy assessment}

This involved assessment of five skills: (1) Identify the initial sound of words (phonological awareness), (2) Know your own name (print awareness), (3) Recognize letters (alphabet knowledge), (4) Recognize everyday words (print awareness), (5) Recognize names in written form (print awareness). The child's skill level was measured by asking increasingly more complex questions for each feature. Assessment of any of the literacy skills was stopped if a child failed to correctly answer a question. The children's responses were scored with a rubric using a 4-point scale (see Appendix A). At the beginning each part of the literacy assessment, the child was given two practice items.

For example, the process for the literacy assessment item of "Identify the initial sound of words" involved stimulus material consisting of twelve words in everyday use, and each word consisted of two to three phonemes. After hearing the word, the child was asked to say the first sound in the word. Because many children would identify the name of the letter rather than the sound, they were given feedback on their responses to the practice items to make sure that they understood the task. If a child failed to identify the initial sound of the first word given, they would receive no points for that part of the assessment. If a child answered the first item correctly, a new word was then presented. Reliability analyses using Cronbach's alpha showed that there were satisfactory results for the overall Literacy pretest $(\alpha=0.63$ ) and posttest $(\alpha=0.79$ ).

\section{Digital literacy measures}

Measurement involved an assessment of cognitive and social-emotional skills that are considered prerequisites of digital literacy. Since this procedure was supplemental to, and independent of, the general classroom literacy assessment, data on these measures were gathered from 5 randomly chosen participants from each classroom (i.e., 5 children per condition). The average age of these 15 children ( 8 girls and 7 boys) was 5.47 years $(S D=0.33$ ) which was similar to the average age for the whole sample.

Cognitive skills items assessed early expressions of multimodality and critical thinking, abstract and reflective thinking (Kazakoff, 2015; Wenner et al., 2008). The measure linked the items to 
storytelling and operationalized these items as recall of a past event, planning for a new event and picture reading. For instance, recall of a past experience is important for story comprehension. It hinges on reflection about the context of an event (who, where, and when), and on the ability to explain an unfolding story (how and why). The ability to "read" a picture is an important skill in digital literacy. This facet in the digital literacy measure was the counterpart of the purely textoriented items in the literacy assessment.

Social-emotional skills were assessed by communication about the self with others through digital platforms ( $\mathrm{Ng}, 2015)$. An important aspect of this skill in early childhood concerns is having a sense of self-identity (Marsh et al., 2005). The development of self-identity includes knowing one's name, age, and gender. In addition, it concerns how the child's understands his/her place in the world (Raburu, 2015).

\section{Digital literacy assessment}

The digital literacy measure consisted of a rubric with the following items: (1) Recall of a past event (cognitive skills); (2) Plan an event (cognitive skills); (3) Read a picture (multimodality cognitive skills); (4) Understand one's own identity (social-emotional skills); (5) Engage in a conversation (social-emotional skills).

Administration of the digital literacy measures followed the same procedure as for the literacy test (see Appendix B for all items and the scoring rubric). For the measure "Recall a past event", the items were focused on children's ability to identify details from a single, personal experience. Each child was asked to recall a recent holiday experience. If a child could not recall a single experience, the score for this test item would be zero points. If a child recalled an event he/she was asked to provide details about that experience. The allotted points would then depend on the number of details that were given (i.e., what, where, when, with who, and how). If a child started to mention another event, the experimenter would redirect the discussion to the original event. If the child could not do this or could not give details, the questions for this item ended. Reliability analyses using Cronbach's alpha showed that there were satisfactory results for the Digital Literacy pretest $(\alpha=0.65)$ and posttest $(\alpha=0.87)$.

\section{Procedure}

The intervention study consisted of three phases: pretest (Week 1), implementation (Weeks 2-4), and posttest (Week 5). In the pretest, a group of 3 to 5 children gathered in the reading room of the school where the experimenter and a research assistant were present. The experimenter would then engage with each child, in turn, for the assessments. Administration of the literacy assessment took 10-15 minutes for each child, while the digital literacy assessment took 25-35 minutes for each child. During the assessment process for each child, the other children in the room engaged in playful activities led by the research assistant.

During the implementation phase, in the control condition, the children participated in the regular literacy-focused classroom activities led by the teacher and with the experimenter present. In the experimental conditions (storytelling and digital storytelling), the activities were given by the experimenter while the regular classroom teacher was present to assist with the children. The 
overall structure of these activities was the same in both conditions (see also Table 1). First, there was storytelling. Next, there was a whole-class discussion about the story, and finally, there were follow-up activities. Each storytelling session began with the experimenter explaining the rules for the session and preparing the children for the story by informing them about the title, characters, and main idea.

In the oral storytelling condition, the experimenter then read the story along with presenting some visual clues to the children. While in the digital storytelling condition, the story was prerecorded and included texts, pictures, voices, and sounds, then was digitally presented using a projection device. The story in the first storytelling session was about a boy who likes his name, followed by a whole-class discussion about the story. This was followed by of two story-related activities. One of these was an individual project with a focus on children's creativity, for example, children designed a book label using the letters of their own name. The second follow-up activity was a group project, such as dramatic play involving an exchange of the children's name cards.

The posttest was administered in the week following the three activity sessions with a similar procedure to the pretest sessions.

\section{Data analysis}

Eight of the 45 children participating in the intervention study did not complete both the literacy pretest and posttest because of absence ( 5 children) or because they were special needs students ( 3 children). Only complete data for the 37 children who completed all assessment tasks were used in the final analyses.

Because the distribution of scores on some measures in the pretest and posttest violated measurement assumptions for normality and homogeneity of variance, we report the findings using non-parametric tests (i.e., Kruskal Wallis $\mathrm{H}$ test). Significant findings were followed by post hoc tests (i.e., Mann Whitney U test); two-tailed tests were used with alpha set at $0.017(0.05 / 3)$, using Bonferroni corrections for multiple tests. For effect size, we report the r-statistic (Field, 2005). This statistic is qualified as small, medium, and large effects for respectively the values $r=$ $0.10, r=0.30$, and $r=0.50$, respectively. For change in assessment from pre to post, key assumptions for gain scores (i.e., posttest score minus the pretest score) were met to assess change using Analysis of Variance (ANOVA), followed by Tukey HSD post hoc analysis after significance. For these effect sizes, we report the d-statistic (Cohen, 1988). The findings are classified as follows: small for $d=0.20$, medium for $d=0.50$, and large for $d=0.80$, respectively.

\section{RESULTS}

\section{Development of literacy skills}

Table 2 presents the mean item scores and standard deviations for the literacy and digital literacy assessments for each group (control condition; oral storytelling condition; and digital storytelling conditions). These mean scores showed that the overall scores of the participants in all three 
conditions at pretest and posttest were below the mid-scale value of 2 . In addition, there were moderate levels of variance, as indicated by the standard deviations.

Table 2

Descriptive statistics for Literacy Assessment for each condition before and after the intervention activities

\begin{tabular}{cc}
\hline Pretest: Mean (SD) & Posttest: Mean (SD) \\
\hline $1.63(0.45)$ & $1.66(0.47)$ \\
$1.69(0.41)$ & $1.92(0.50)$ \\
$1.80(0.32)$ & $2.18(0.34)$ \\
\hline $1.71(0.39)$ & $1.91(0.48)$ \\
\hline
\end{tabular}

Note. Scored on a 0-4 point scale, 4 is the highest score.

The scores on the literacy pretest did not differ between conditions, $H(36)=0.648, p=0.723$. In contrast, there was a statistically significant difference on the literacy posttest between conditions, $H(36)=8.26, p=0.016$. Post hoc tests showed that there was a statistically significant and large effect for the comparison between the Control condition and Digital Storytelling condition, $U(25)=128.50, z=2.82, p=0.005, r=0.56$. There was no difference between the Control and Storytelling condition or between the Storytelling and Digital Storytelling condition, respectively $U(25)=81.50, z=0.193, p=0.847 ; U(25)=90.50, z=0.485, p=0.485$.

The boxplots for the Literacy posttest, shown in Figure 1, provide a visual presentation of differences in outcomes by condition. The shaded areas in each box represent the mid $50 \%$ of the scores. The horizontal line in the box is the median score in each condition. The top (or bottom) $25 \%$ of scores are shown in the distance between the highest (or lowest) horizontal line and the highest (or lowest) edge of the shaded box. The shaded boxes of the Control and Digital Storytelling condition do not overlap (indicating significant difference between these two groups as identified by the statistical tests). In contrast, there is some overlap between the Oral Storytelling and Digital Storytelling conditions. The median scores of the two experimental conditions are also similar.

Data analyses for the learning gain (Lgain) scores showed a mean overall improvement for literacy skills of $0.21(S D=0.21)$. For the Control, Storytelling and Digital Storytelling condition, the mean Lgain score was respectively for each condition, $M=0.03(S D=0.08), M=0.20(S D=0.19)$, and $M=0.38(S D=0.18)$. The ANOVA for Lgain scores showed that there was a statistically significant difference between conditions, $F(2,33)=14.74, p<0.001$. Post hoc comparisons indicated that the Control had a lower Lgain score than the Storytelling condition, $p=0.014, d=1.17$, and also a lower Lgain score than the Digital Storytelling condition, $p<0.001, d=2.53$. For both comparisons, a large effect size was obtained. In addition, the analysis showed that there was a significantly higher Lgain score in the Digital Storytelling compared to the Storytelling condition, $p=0.008, d=0.97$, and with a large effect size. 


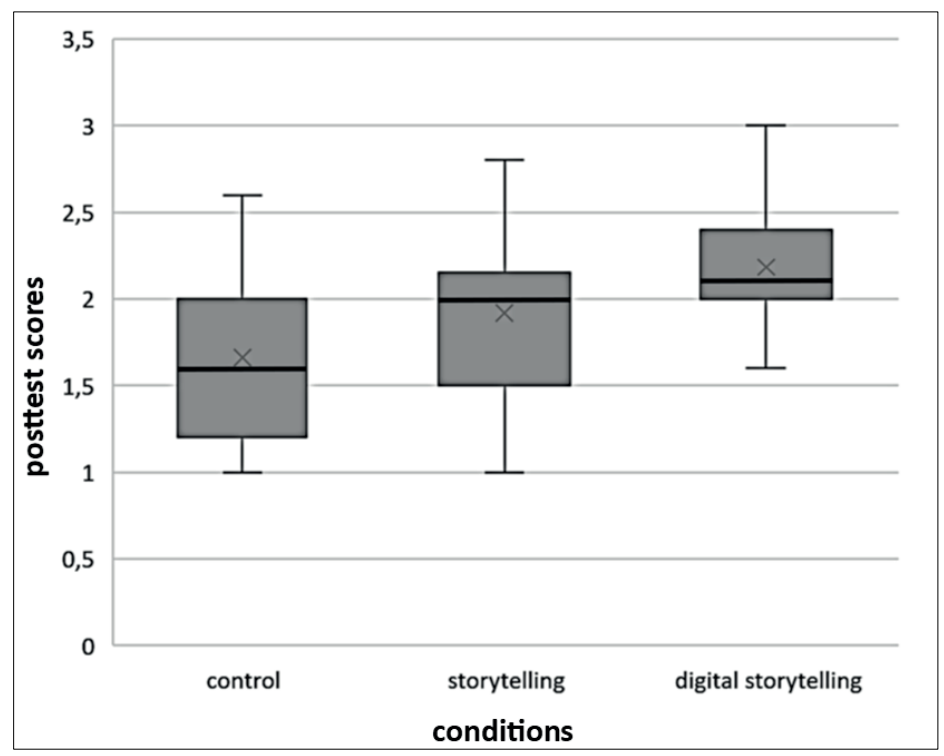

Figure 1. Boxplot for the literacy posttest scores for each condition.

\section{Development of digital literacy skills}

The pretest results showed that all participants $(n=15)$ in the three conditions (Control, Oral Storytelling, Digital Storytelling) had comparable digital skills at the start of the activities, $M=1.88$ ( $S D=0.23), M=1.92(S D=0.18)$, and $M=1.88(S D=0.23)$. After the activities, the posttest results were $M=2.04(S D=0.22), M=2.80(S D=0.28)$, and $M=3.00(S D=0.42)$. The results also showed that the median score and the distribution of the Digital Literacy posttest scores in the control condition did not overlap with that of the experimental conditions. In contrast, there was an overlap of the distribution of the scores between the two experimental conditions and also the median scores were close to each other.

The Kruskal-Wallis test showed that there was no statistically significant difference between conditions on the Digital Literacy pretest, $H(15)=0.153, p=0.926$. In contrast, a statistically significant difference was found on the posttest, $H(15)=9.40, p=0.09$. Post hoc tests showed that there was a statistically significant, and large difference for the comparison between the Control and Storytelling condition, $U(10)=24.50, z=2.58, p=0.008, r=0.82$, and for the comparison between the Control and Digital Storytelling condition, $U(10)=25, z=2.65, p=0.008, r=0.84$. The two experimental conditions did not differ significantly, $U(10)=15.50, z=0.64, p=0.523$.

Data analyses for the digital learning gain (DLgain) scores showed that all conditions showed a mean overall improvement for digital literacy skills of $0.72(S D=0.45)$. For the Control, Storytelling and Digital Storytelling condition, the mean DLgain was respectively, $M=0.16(S D=0.09), M=$ $0.88(S D=0.18)$, and $M=1.12(S D=0.23)$. The ANOVA for DLgain showed that there was a statistically significant difference between conditions, $F(2,14)=40.70, p<0.001$. Post hoc comparisons indicated that the Control had a lower DLgain than the Storytelling condition, $p<$ $0.001, d=5.06$, and also a lower DLgain than the Digital Storytelling condition, $p<0.001, d=5.50$. 
For both comparisons, a large effect size was obtained. In addition, the analysis showed that there was no significant difference for DLgain between the Digital Storytelling compared to the Storytelling condition, $p=0.051$.

\section{DISCUSSION}

Increased attention to (digital) literacy goals in early childhood education has been accompanied by more formalized educational practices. These endeavors have been criticized as being out of tune with how young children (like to) learn (Miller \& Almon, 2009). The present study investigated the design and effectiveness of a storytelling approach to achieving digital literacy goals. The storytelling activities were systematically structured by adopting the events of instructional design proposed by Gagné (Smith \& Ragan, 2005).

The core content of these activities involved storytelling to enable a natural, playful way of learning. This also is in accord with the view that storytelling is a cornerstone of digital literacy development. Storytelling provided the objectives, models, and motivation for literacy skills application. For example, storytelling in the first activity revolved around a child's name, and included how to say, spell and write that name. Follow-up activities provided opportunities for practice of the presented skills. These activities stimulated the children to apply what they had learned to their own situations. This format was the same across the two experimental conditions, although in the digital storytelling condition the story was prerecorded, using multimedia including texts, pictures, voices, and sounds. In the design of the stories, special attention was given to considerations from multimedia learning theory (Mayer \& Moreno, 2003). That is, the design aimed for a strong match between the verbal and nonverbal information in the stories (Takacs, Swart, \& Bus, 2015). In the digital storytelling activities, the digital content aimed to support the children's activities and engagement with the real world was highlighted in accord with the statement published by NAEYC \& Fred Rogers Center (2012).

The measures used assessed a broad spectrum of literacy skills in early childhood. The use of rubrics to implement authentic assessment tasks (Bagnato, Goins, Pretti-Frontczak, \& Neisworth, 2014) also avoided subjectivity in the measurement processes by the use of the rubric.

The administration of a pretest afforded an assessment of learning gains and enabled us to test the comparability of the children's starting levels of (digital) literacy skills across classrooms. Pretest scores indicated that there were no differences in the mean skills levels in classrooms/conditions at the pretest assessments.

The digital storytelling activities had a significant effect on the children's literacy skills development. Whereas the children in the control condition showed little improvement across the intervention period, the children in the experimental conditions achieved significant gains in literacy skills. Findings suggested that the digital storytelling activities also enhanced the children's digital literacy skills. For digital literacy development, significant gains were found only for the experimental conditions. Storytelling activities seemed to be equally effective, across the experimental conditions, for developing the children's digital literacy skills. 
The findings showed that the effects of the digital literacy activities on digital literacy development were promising. However, this part of the research was exploratory and involved only a small sample of children who participated in the assessments. It is recommended that future research include bigger sample sizes to form more definitive conclusions on the effects of storytelling sessions on digital literacy development. A second methodological limitation of the research was that the storytelling activities were led by the experimenter while the regular activities in the control condition were taught by the classroom teacher. During the activities, the teacher or experimenter served as a teaching assistant and vice versa. We decided to adopt this course of action to disrupt as little as possible the normal classroom routine in the control classroom.

\section{CONCLUSIONS}

Overall, the research indicated that the integration of a storytelling approach with the didactic approach of Gagné's nine events of instruction is a promising approach for enhancing literacy and digital literacy development in early childhood classrooms. Nevertheless, to move beyond the entertainment or novelty effect that digital storytelling might bring (Campbell, 2012), future studies might consider designing a more extensive series of activities to reduce the novelty effect and to maximize all possible benefits that might result from digital storytelling activities. 


\section{APPENDIX A}

\section{Scoring rubric for the literacy assessment}

\begin{tabular}{|c|c|c|c|c|c|c|}
\hline \# & Key skills assessed & 0 point & 1 point & 2 points & 3 points & 4 points \\
\hline 1 & $\begin{array}{l}\text { Phonological } \\
\text { awareness } \\
\text { Identify initial sound } \\
\text { of words; oral } \\
\text { presentation }\end{array}$ & $\begin{array}{l}\text { Needs help } \\
\text { to identify } \\
\text { initial sound }\end{array}$ & $\begin{array}{l}\text { 1-4 words } \\
\text { identified }\end{array}$ & $\begin{array}{l}5-6 \text { words } \\
\text { identified }\end{array}$ & $\begin{array}{l}7-8 \text { words } \\
\text { identified }\end{array}$ & $\begin{array}{l}\text { 9-10 words } \\
\text { identified }\end{array}$ \\
\hline 2 & $\begin{array}{l}\text { Print awareness and } \\
\text { early comprehension } \\
\text { Knows own name; } \\
\text { oral presentation }\end{array}$ & $\begin{array}{l}\text { Needs help } \\
\text { to say own } \\
\text { name }\end{array}$ & $\begin{array}{l}\text { Own name } \\
\text { said } \\
\text { clearly }\end{array}$ & $\begin{array}{l}\text { Own name } \\
\text { said } \\
\text { clearly; } \\
\text { spells it } \\
\text { correctly; }\end{array}$ & $\begin{array}{l}\text { Own name } \\
\text { said clearly; } \\
\text { spells it } \\
\text { correctly; } \\
\text { writes name } \\
\text { from } \\
\text { example }\end{array}$ & $\begin{array}{l}\text { Own name } \\
\text { said clearly; } \\
\text { spells it } \\
\text { correctly; } \\
\text { writes name } \\
\text { without } \\
\text { example }\end{array}$ \\
\hline 3 & $\begin{array}{l}\text { Alphabet recognition } \\
\text { Recognizes letters; } \\
\text { written (story book) }\end{array}$ & $\begin{array}{l}\text { Needs cues } \\
\text { to recognize } \\
\text { any letters } \\
\text { in a } \\
\text { storybook }\end{array}$ & $\begin{array}{l}\text { 1-4 letters } \\
\text { recognized } \\
\text { in a story- } \\
\text { book }\end{array}$ & $\begin{array}{l}\text { 5-6 letters } \\
\text { recognized } \\
\text { in a story- } \\
\text { book }\end{array}$ & $\begin{array}{l}\text { 7-8 letters } \\
\text { recognized } \\
\text { in a story- } \\
\text { book }\end{array}$ & $\begin{array}{l}\text { 9-10 letters } \\
\text { recognized } \\
\text { in a story- } \\
\text { book }\end{array}$ \\
\hline 4 & $\begin{array}{l}\text { Print awareness } \\
\text { Recognizes daily } \\
\text { words; written } \\
\text { presentation (story } \\
\text { book) }\end{array}$ & $\begin{array}{l}\text { Needs help } \\
\text { to recognize } \\
\text { any words } \\
\text { in a } \\
\text { storybook }\end{array}$ & $\begin{array}{l}1 \text { word } \\
\text { recognized } \\
\text { in a story- } \\
\text { book }\end{array}$ & $\begin{array}{l}2-3 \text { words } \\
\text { recognized } \\
\text { in a story- } \\
\text { book }\end{array}$ & $\begin{array}{l}4-5 \text { words } \\
\text { recognized } \\
\text { in a story- } \\
\text { book }\end{array}$ & $\begin{array}{l}6 \text { words } \\
\text { recognized } \\
\text { in a story- } \\
\text { book }\end{array}$ \\
\hline 5 & $\begin{array}{l}\text { Print awareness } \\
\text { Recognizes names in } \\
\text { written form; written } \\
\text { presentation }\end{array}$ & $\begin{array}{l}\text { Needs help } \\
\text { to recognize } \\
\text { friend's } \\
\text { name on } \\
\text { attendance } \\
\text { list }\end{array}$ & $\begin{array}{l}\text { Friend's } \\
\text { name } \\
\text { recognized } \\
\text { on atten- } \\
\text { dance list }\end{array}$ & $\begin{array}{l}\text { 2-3 names } \\
\text { recognized } \\
\text { on atten- } \\
\text { dance list }\end{array}$ & $\begin{array}{l}\text { 4-5 names } \\
\text { recognized } \\
\text { on atten- } \\
\text { dance list }\end{array}$ & $\begin{array}{l}6 \text { names } \\
\text { recognized } \\
\text { on atten- } \\
\text { dance list }\end{array}$ \\
\hline
\end{tabular}




\section{APPENDIX B}

\section{Scoring rubric for the digital literacy test}

\begin{tabular}{|c|c|c|c|c|c|c|}
\hline$\#$ & Item (skill) & 0 point & 1 point & 2 points & 3 points & 4 points \\
\hline 1 & $\begin{array}{l}\text { Recall a past } \\
\text { event } \\
\text { (cognitive) }\end{array}$ & $\begin{array}{l}\text { No } \\
\text { response } \\
\text { given }\end{array}$ & $\begin{array}{l}\text { Contains } \\
\text { information } \\
\text { about: } \\
\text { 'what' }\end{array}$ & $\begin{array}{l}\text { Contains } \\
\text { information } \\
\text { about: what } \\
\text { and where, } \\
\text { when, who }\end{array}$ & $\begin{array}{l}\text { Contains } \\
\text { information } \\
\text { on: what, } \\
\text { where, when, } \\
\text { who ( } 3 \text { or } 4 \\
\text { pieces of } \\
\text { information) }\end{array}$ & $\begin{array}{l}\text { Contains } \\
\text { information } \\
\text { on: what, } \\
\text { where, when, } \\
\text { who, how, why }\end{array}$ \\
\hline 2 & $\begin{array}{l}\text { Plan an } \\
\text { event } \\
\text { (cognitive) }\end{array}$ & $\begin{array}{l}\text { No } \\
\text { response } \\
\text { given }\end{array}$ & $\begin{array}{l}\text { Contains } \\
\text { information } \\
\text { about 'what' }\end{array}$ & $\begin{array}{l}\text { Contains } \\
\text { information } \\
\text { on what and } \\
\text { where/when/ } \\
\text { who }\end{array}$ & $\begin{array}{l}\text { Contains some } \\
\text { information } \\
\text { on: what, who, } \\
\text { where, when (3 } \\
\text { or 4) }\end{array}$ & $\begin{array}{l}\text { Contains } \\
\text { information } \\
\text { on: what, who, } \\
\text { where, when, } \\
\text { how, why }\end{array}$ \\
\hline 3 & $\begin{array}{l}\text { Read a } \\
\text { picture } \\
\text { (cognitive) }\end{array}$ & $\begin{array}{l}\text { Needs } \\
\text { help to } \\
\text { identify } \\
\text { features } \\
\text { observed } \\
\text { in a } \\
\text { picture }\end{array}$ & $\begin{array}{l}\text { Identifies } 2 \\
\text { features } \\
\text { observed in } \\
\text { a picture(s) }\end{array}$ & $\begin{array}{l}\text { Mentions } 2 \\
\text { features } \\
\text { observed in } \\
\text { picture; } \\
\text { Infers story of } \\
\text { picture }\end{array}$ & $\begin{array}{l}\text { Mentions 3-4 } \\
\text { features } \\
\text { observed in } \\
\text { pictures; Infers } \\
\text { story of } 2 \\
\text { pictures }\end{array}$ & $\begin{array}{l}\text { Mentions 3-4 } \\
\text { features } \\
\text { observed in } \\
\text { pictures; Infers } \\
\text { story of } 3 \\
\text { pictures }\end{array}$ \\
\hline 4 & $\begin{array}{l}\text { Recognize } \\
\text { own identity } \\
\text { (social- } \\
\text { emotional) }\end{array}$ & $\begin{array}{l}\text { Needs } \\
\text { help to } \\
\text { mention } \\
\text { own full } \\
\text { name }\end{array}$ & $\begin{array}{l}\text { Mentions } \\
\text { own full } \\
\text { name }\end{array}$ & $\begin{array}{l}\text { Mentions } \\
\text { own full } \\
\text { name and age }\end{array}$ & $\begin{array}{l}\text { Mentions own } \\
\text { full name } \\
\text { clearly; age and } \\
\text { own birthday } \\
\text { (incomplete) }\end{array}$ & $\begin{array}{l}\text { Mentions own } \\
\text { full name } \\
\text { clearly; age; } \\
\text { own birthday } \\
\text { (complete: } \\
\text { date, month, } \\
\text { and year) }\end{array}$ \\
\hline 5 & $\begin{array}{l}\text { Engage in } \\
\text { conversation } \\
\text { (social- } \\
\text { emotional) }\end{array}$ & $\begin{array}{l}\text { Passively } \\
\text { responds } \\
\text { to } \\
\text { questions }\end{array}$ & $\begin{array}{l}\text { Needs } \\
\text { reminders to } \\
\text { follow } \\
\text { etiquette of } \\
\text { conversation }\end{array}$ & $\begin{array}{l}\text { Needs } \\
\text { reminders to } \\
\text { follow some } \\
\text { etiquette } \\
\text { rules of } \\
\text { conversation }\end{array}$ & $\begin{array}{l}\text { Needs } \\
\text { reminders to } \\
\text { follow a few } \\
\text { etiquette rules } \\
\text { of conversation }\end{array}$ & $\begin{array}{l}\text { Follows all } \\
\text { rules of } \\
\text { conversation } \\
\text { (e.g., maintain } \\
\text { eye contact; } \\
\text { wait for his/her } \\
\text { turn to speak; } \\
\text { asks correctly; } \\
\text { responds } \\
\text { correctly) }\end{array}$ \\
\hline
\end{tabular}




\section{REFERENCES}

Agosto, D. (2016). Why storytelling matters. Children and Libraries, 14(2), 21-26.

https://doi.org/10.5860/cal.14n2

Ba, H., Tally, W., \& Tsikalas, K. (2002). Investigating children's emerging digital literacies. The Journal of Technology, Learning, and Assessment, 1(4), 1-47.

Bagnato, S. J., Goins, D. D., Pretti-Frontczak, K., \& Neisworth, J. T. (2014). Authentic assessment as "best practice" for early childhood intervention: National consumer social validity research. Topics in Early Childhood Special Education, 34(2), 116-127.

https://doi.org/10.1177/0271121414523652

Bassok, D., Latham, S., \& Rorem, A. (2016). Is kindergarten the new first grade? AERA Open, 2(1), 1-31. https://doi.org/10.1177/2332858415616358

Brígido-Corachán, A. M., \& Gregori-Signes, C. (2014). Digital storytelling and its expansion across educational context. In A. M. Brígido-Corachán, \& C. Gregori-Signes (Eds.), Appraising digital storytelling across educational contexts (pp. 13-29). Valéncia: Universitat de Valéncia.

Brown, J., \& Rolfe, S. A. (2005). Use of child development assessment in early childhood education: Early childhood practitioner and student attitudes toward formal and informal testing. Early Child Development and Care, 175(3), 193-202. https://doi.org/10.1080/0300443042000266240

Burnett, C., Merchant, G., Pahl, K., \& Rowsell, J. (2014). The (im)materiality of literacy: The significance of subjectivity to new literacies research. Discourse: Studies in the Cultural Politics of Education, 35(1), 90-103. https://doi.org/10.1080/01596306.2012.739469

Campbell, T. A. (2012). Digital storytelling in an elementary classroom: Going beyond entertainment. Paper presented at the ICEEPSY 2012, Turkey.

Cassell, J. (2004). Towards a model of technology and literacy development: Story listening systems. Journal of Applied Developmental Psychology, 25(1), 75-105. https://doi.org/10.1016/j.appdev.2003.11.003

Coskie, T., Trudel , H., \& Vohs, R. (2010). Creating community through storytelling. Talking Points, 22(1), 2-9.

Egan, K. (1985). Teaching as storytelling: A non-mechanistic approach to planning teaching. Journal of Curriculum Studies, 17(4), 397-406. https://doi.org/10.1080/0022027850170405

Egan, K. (1986). Teaching as storytelling: An alternate approach to teaching and curriculum in the elementary school. University of Chicago Press.

Eshet-Alkalai, Y., \& Chajut, E. (2009). Changes over time in digital literacy. Cyberpsychology \& Behavior, 12(X), 1-3. https://doi.org/10.1089/cpb.2008.0264

Eshet-Alkali, Y., \& Amichai-Hamburger, Y. (2004). Experiments in digital literacy. Cyberpsychology \& Behavior, 7(4), 421-429.

Eshet, Y. (2012). Thinking in the digital era: A revised model for digital literacy. Issues in Informing Science and Information Technology, 9, 267-276. https://doi.org/10.28945/1621

Field, A. (2005). Discovering statistics using IBM SPSS statistics (2nd ed.). Sage. 
Fletcher-Flinn, C. M. (2015). Editorial: Frontiers in the acquisition of literacy. Frontiers in Psychology, 6, 1-2. https://doi.org/10.3389/fpsyg.2015.01019

Foulin, J. N. (2005). Why is letter-name knowledge such a good predictor of learning to read? Reading and Writing, 18(2), 129-155. https://doi.org/10.1007/s11145-004-5892-2

Justice, L. M., \& Ezell, H. K. (2001). Word and print awareness in 4-year old children. Child Language Teaching and Theraphy, 17(3), 20. https://doi.org/10.1177/026565900101700303

Kamii, C., \& Manning, M. (2005). Dynamic Indicators of Basic Early Literacy Skills (DIBELS): A tool for evaluating student learning? Journal of Research in Childhood Education, 20(2), 75-90. https://doi.org/10.1080/02568540509594553

Kassow, D. Z. (2006). Environmental print awareness in young children. Talaris Research Institute, 1(3), $1-8$.

Katuscáková, M., \& Katuscák, M. (2013). The effectiveness of storytelling in transferring different types of knowledge. [Paper presentation] European Conference on Knowledge Management, Kidmore End.

Kazakoff, E. R. (2015). Technology-based literacies for young children: Digital literacy through learning to code. In K. L. Heider, \& M. R. Jalongo (Eds.), Young children and families in the information age, educating the young child (pp. 43-60). Springer Science \& Business Media.

Kearney, M., Jones, G., \& Roberts, L. (2011). An emerging learning design for student-generated 'iVideos'. [Paper presentation] at the 6th International LAMS \& Learning Design Conference, LAMS Foundation.

Kern, R. (2000). Literacy and language teaching. Oxfors University Press.

Kildan, A. O., \& Incikabi, L. (2015). Effects on the technological pedagogical content knowledge of early childhood teacher candidates using digital storytelling to teach mathematics. Education 3-13, 43(3), 238-248. https://doi.org/10.1080/03004279.2013.804852

Lambert, J. (2010). Digital storytelling cookbook (pp. 1-35).

https://wrd.as.uky.edu/sites/default/files/cookbook.pdf

Lonigan, C. J., Allan, N. P., \& Lerner, M. D. (2011). Assessment of preschool early literacy skills: Linking children's educational needs with empirically supported instructional activities. Psychology in the Schools, 48(5), 488-501. https://doi.org/10.1002/pits.20569

Marsh, J. (2016). The digital literacy skills and competences of children of pre-school age. Media Education: Studies and Research, 7(2), 197-214. https://doi.org/10.14605/MED721603

Marsh, J., Brooks, G., Hughes, J., Ritchie, L., Roberts, S., \& Wright, K. (2005). Digital beginnings: Young children's use of popular culture, media and new technologies.

http://www.digitalbeginnings.shef.ac.uk/DigitalBeginningsReport.pdf

Martin, A., \& Grudziecki, J. (2006). DigEuLit: Concepts and tools for digital literacy development. Innovation in Teaching and Learning in Information and Computer Sciences, 5(4), 1-19. https://doi.org/10.11120/ital.2006.05040249

Mayer, R. E., \& Moreno, R. (2003). Nine ways to reduce cognitive load in multimedia learning. Educational Psychologist, 38(1), 43-52. https://doi.org/10.1207/S15326985EP3801_6

McLachlan, C., \& Arrow, A. (2010). Alphabet and phonological awareness: Can it be enhanced in the early childhood setting? International Research in Early Childhood Education, 1(1), 84-94. 
Meadows, D. (2003). Digital storytelling: Research-based practice in new media. Visual Communication, 2(2), 189-193. https://doi.org/10.1177/1470357203002002004

Miller, E., \& Almon, J. (2009). Crisis in the kindergarten: Why children need to play in school. Alliance for Childhood.

Murray, B. A., Stahl, S. A., \& Ivey, M. G. (1996). Developing phoneme awareness through alphabet books. Reading and Writing, 8(4), 307-322. https://doi.org/10.1007/bf00395111

Muter, V. (1994). Influence of phonological awareness and letter knowledge on beginning reading and spelling development. In C. Hulme, \& M. Snowling (Eds.), Reading development and dyslexia (pp. 45-62). Whurr.

Myers, C. L., McBride, S. L., \& Peterson, C. A. (1996). Transdisciplinary, play-based assessment in early childhood special education: An examination of social validity. Topics in Early Childhood Special Education, 16(1), 102-126. https://doi.org/10.1177/027112149601600109

NAEYC. (1998). Learning to read and write: Developmentally appropriate practices for young children. Young Children, 53(4), 30-46.

NAEYC, \& Fred Rogers Center for Early Learning and Children's Media. (2012). [Position Statement] Technology and interactive media as tools in early childhood programs serving children from birth through age 8. https://www.naeyc.org/resources/topics/technology-and-media

National Research Council. (2000). Eager to learn: Educating our preschoolers. The National Academies Press. https://doi.org/10.17226/9745

$\mathrm{Ng}, \mathrm{W}$. (2015). Digital literacy: The overarching element for successful technology integration. In W. Ng, New digital technology in education: Conceptualizing professional learning for educators (pp. 125-145). Springer International Publishing.

Nicolopoulou, A., Cortina, K. S., Ilgaz, H., Cates, C. B., \& de Sa, A. B. (2015). Using a narrative- and playbased activity to promote low-income preschoolers' oral language, emergent literacy, and social competence. Early Childhood Research Quarterly, 31, 147-162. https://doi.org/10.1016/j.ecresq.2015.01.006

Owodally, A. M. A. (2015). Code-related aspects of emergent literacy: How prepared are preschoolers for the challenges of literacy in an EFL context? Early Child Development and Care, 185(4), 509527. https://doi.org/10.1080/03004430.2014.936429

Peck, J. (1989). Using storytelling to promote language and literacy development. The Reading Teacher, 43(2), 138-141.

Phillips, L. (2013). Storytelling as pedagogy. Literacy learning: The middle years, 21(2), ii-iv.

Piasta, S. B., \& Wagner, R. K. (2010). Developing early literacy skills: A meta-analysis of alphabet learning and instruction. Reading Research Quarterly, 45(1), 8-38. https://doi.org/10.1598/RRQ.45.1.2

Porter, B. (2005). DigiTales: The art of telling digital stories. Bernajean Porter Consulting.

Preradovic, N. M., Lesin, G., \& Boras, D. (2016). Introduction of digital storytelling in preschool education: A case study from Croatia. Digital Education Review, 30, 94-105.

Psomos, P., \& Kordaki, M. (2015). A novel educational digital storytelling tool focusing on students misconceptions. Procedia - Social and Behavioral Sciences, 191, 82-86.

https://doi.org/10.1016/j.sbspro.2015.04.476 
Pullen, P. C., \& Justice, L. M. (2003). Enhancing phonological awareness, print awareness, and oral language skills in preschool children. Intervention in School and Clinic, 39(2), 87-98.

Raburu, P. A. (2015). The self- who am I?: Children's identity and development through early childhood education. Journal of Educational and Social Research, 5(1), 95-102. https://doi.org/10.5901/jesr.2015.v5n1p95

Robin, B. R. (2008). Digital storytelling: A powerful technology tool for the 21st century classroom. Theory Into Practice, 47(3), 220-228. https://doi.org/10.1080/00405840802153916

Robinson, E. J., Einav, S., \& Fox, A. (2013). Reading to learn: Prereaders' and early readers' trust in text as a source of knowledge. Developmental Psychology, 49(3), 505-513. https://doi.org/10.1037/a0029494

Roney, R. C. (1996). Storytelling in the classroom: Some theoretical thoughts. Storytelling World, 9 (Winter/Spring), 7-9.

Sadik, A. (2008). Digital storytelling: A meaningful technology-integrated approach for engaged student learning. Educational Technology Research and Development, 56(4), 487-506. https://doi.org/10.1007/s11423-008-9091-8

Sefton-Green, J., Marsh, J., Erstad, O., \& Flewitt, R. (2016). Establishing a research agenda for the digital literacy practices of young children. A white paper for COST Action IS1410. http://digilitey.eu/wp-content/uploads/2015/09/DigiLitEYWP.pdf

Smith, P. L., \& Ragan, T. J. (2005). Instructional design (3rd ed.). Wiley.

Sonck, N., Livingstone, S., Kuiper, E., \& de Haan, J. (2011). Digital literacy and safety skills. http://eprints.Ise.ac.uk/33733/1/Digital\%20literacy\%20and\%20safety\%20skills\%20(Isero).pdf

Takacs, Z. K., Swart, E. K., \& Bus, A. G. (2015). Benefits and pitfalls of multimedia and interactive features in technology-enhanced storybooks: A meta-analysis. Review of Educational Research, 85(4), 698-739. https://doi.org/10.3102/0034654314566989

Wenner, J. A., Burch, M. M., Lynch, J. S., \& Bauer, P. J. (2008). Becoming a teller of tales: Associations between children's fictional narratives and parent-child reminiscence narratives. Journal of Experimental Child Psychology, 101(1), 1-19. https://doi.org/10.1016/j.jecp.2007.10.006

Westerveld, M. F., Trembath, D., Shellshear, L., \& Paynter, J. (2015). A systematic review of the literature on emergent literacy skills of preschool children with autism spectrum disorder. The Journal of Special Education, 50(1), 37-48. https://doi.org/10.1177/0022466915613593

Wood, J., \& McLemore, B. (2001). Critical components in early literacy - knowledge of the letters of the alphabet and phonics instruction. The Florida Reading Quarterly, 38(2), 1-8.

Yuksel-Arslan, P., Yildirim, S., \& Robin, B. R. (2016). A phenomenological study: Teachers' experiences of using digital storytelling in early childhood education. Educational Studies, 42(5), 427-445. https://doi.org/10.1080/03055698.2016.1195717 


\section{Enhancing storytelling activities to support early (digital) literacy development in early childhood education}




\begin{abstract}
When storytelling is combined with play-based activities, it can provide an effective stimulus for early literacy. The present study investigated the effects of a structured storytelling approach on the development of young children's literacy and digital literacy skills. Three classes in two public kindergartens participated in an experimental study involving 62 children, aged 5-6 years. Each classroom was assigned to one of three experimental conditions. In one classroom, the children engaged in their regular literacy activities. In a second classroom, literacy development was supported with storytelling and associated play-based activities, while in the third classroom, children engaged in digital storytelling and activities. Outcomes were assessed by tests of early literacy and digital literacy skills before and after the 6-week intervention. The findings showed that both storytelling conditions significantly enhanced children's literacy and digital literacy skills. Structured storytelling activities provide a viable and valuable way to enhance literacy and digital literacy in early childhood education.
\end{abstract}

Keywords: storytelling, digital storytelling, emergent literacy, digital literacy, early childhood education 


\section{INTRODUCTION}

Literacy skills in early childhood contribute to the acquisition of reading and writing skills (Brown, 2014) and contribute to overall academic achievement across the school years (McConnell \& Wackerle-Hollman, 2016). Such findings have led to a focus on supporting literacy development in kindergarten. Most of these efforts have involved academically-oriented programs in which much of the available school day is allocated to drill and practice exercises in individual, small-, and large-group contexts (Golbeck, 2001). The challenge taken up in the present study is to develop an effective, child-friendly approach to support young children's literacy development.

While many programs that have focused on drill and practice exercise in individual, small-, and large-group contexts have effectively raised the literacy skills of kindergarten children (McGillFranzen, 2006; Teale et al., 2018), the use of formal instruction in early childhood has been continually debated (Marcon, 1999; Nicolopoulou et al., 2006; Wood \& Hedges, 2016). Gallant (2009) also highlighted the importance of having children's activities as natural as possible, instead of having formal table-top activities, to support children's engagement in learning.

Supporting digital literacy skills development is also of paramount importance in today's world. There have been a rapid and significant increases in the access to, and use of, mobile devices for young children (Miller et al., 2017; Chang et al., 2018). Young children are growing up in environments where mobile phones, tablets, and other forms of digital devices are features of daily communication. Children need to become skilled in handling these digital forms of communication. Literacy development can no longer be limited to traditional text-based reading and writing. It should also include digitized reading and writing which we will call, henceforth, digital literacy development. It is not surprising that a recent report from UNESCO (2018) emphasized the importance of support for pleaded literacy and digital literacy in early childhood education.

The present study describes a series of activities specifically designed to support literacy and digital literacy development in early childhood education. The activities revolved around a structured storytelling approach that essentially consisted of a 6-week intervention. To assess learning, a set of early literacy and early digital literacy measures were developed and administered before and after the intervention. To our knowledge, the approach of creating a series of activities that blend a more formal type of instruction with storytelling, and assessing the effects on literacy and digital skills in early childhood education is a novel one.

\section{STORYTELLING}

Storytelling is a process in which a person uses vocalization, narrative structure, and mental imagery to communicate with an audience (Peck, 1989). The use of storytelling in early childhood education has been widely encouraged because it is entertaining and seen as a natural way of teaching and learning with young children (Cremin et al., 2018). Moreover, empirical research reveals that storytelling enables processes such as language interaction (Lucarevschi, 2016), imagination stimulation (Bežilová, 2019), and cognitive engagement (Phillips, 2000) that have been found to contribute to literacy skills development. Lisenbee and Ford (2018) argue that a 
proper story entails five key literary elements, namely setting, theme, characters, plot, and conflict. When these elements are properly addressed, it develops a story schema that supports comprehension (Stevens et al., 2010) hence storytelling is a good way to deliver content, and provide learning guidance in an interesting and personal way (Kolucki \& Lemish, 2011).

So far, the design of an effective storytelling approach in early childhood education has remained elusive. Stories appear to have been underused for what they can do. They are mainly employed merely for gaining children's attention at the beginning of a classroom activity or for moments of relaxation after the main task has been completed (Roslan, 2008). Thus, it appears that storytelling has yet to prove itself as an activity that can contribute to learning at school.

Cooper (2005) proposed in favor of an approach in which storytelling is complemented with playbased activities. According to this view, storytelling should provide the core information; the storytelling component should engage the children in affective and cognitive experiences around language, print, and stories. During storytelling, the teacher can provide guidance by interacting with the children. The storytelling should be followed by play-based activities in which children can hone their literacy skills. These activities should involve the children in meaningful encounters with letters, sounds, and writing. Cooper argued for an instructional structure in which a storytelling approach is infused by play-based activities. Such an approach turns storytelling into a meaningful and pleasant way for creating a structured, child-friendly stimulus for literacy development in early childhood education.

\section{DIGITAL STORYTELLING}

For many years, storytelling approaches in early childhood education have been limited to traditional forms of text-based reading and writing in which other resources such as puppets, or story-related objects and digitized media were used only occasionally (Boltman \& Druin, 2003). Technological advances have dramatically raised the affordance for enriched storytelling and thereby the possibility of making it more engaging in its own way. The digital tools needed for storytelling - computers, smart phones, audio capture devices - have become more accessible. In addition, a huge number of powerful, yet simple storytelling software programs are now available. The combination of oral storytelling with audio, images, and various digital tools has led to what is now called digital storytelling (Barber, 2016).

Digital storytelling means using technology properly to tell a story. To create a digitized story, designers should pay special attention to personalization (Robin, 2008). Digital storytelling should adopt a specific point of view, contain a dramatic question, and have emotional content to personalize the content of the story. Moreover, in digital storytelling the gift of voice, power of soundtrack, economy, and pacing need to be attended in design to personalize the delivery of the story. All together, these make up the seven elements or features of digital storytelling (Robin, 2008).

The proper usage of these digital elements can contribute to making content more understandable and motivating for young children (e.g. Boerma, Mol, \& Jolles, 2016). Indeed, the elements of economy and gift of voice can be linked to multimedia principles that have been proven to enhance learning (Mayer, 2009). The element of economy is related to the coherence, 
redundancy, modality, and multimedia principles. While, the element of the gift of voice is related to the personalization and voice principles. When digital storytelling is used in early childhood education the effect may be that it familiarizes children with digital media.

\section{MEASUREMENT OF EARLY LITERACY}

Literacy is commonly seen as a set of tangible skills, particularly the cognitive skills of reading and writing. These skills are independent of the context in which such skills are acquired, and of the background of the person who acquires the skills (UNESCO, 2005). Literacy in early childhood has proven to be significantly related to later reading and writing ability, and long-term academic outcomes (Ritchey, 2008). Early literacy is the precursor to conventional forms of reading and writing (Whitehurst \& Lonigan, 1998).

Literacy skills in kindergarten include a number of early skills of awareness and exploration for reading and writing that develop in increasingly complex ways (Missall, Carta, McConnell, Walker, \& Greenwood, 2008). These skills include constrained and unconstrained components (Paris, 2005). Constrained components are also known as technical or decoding skills. Examples include letter knowledge, phonics, and concepts of print. These skills are necessary, but not sufficient, for full literacy. They are best taught and measured systematically as part of a comprehensive language and literacy program. Unconstrained components are meaning-based skills. Examples are oral language, vocabulary, and comprehension. These skills are developed across a person's lifetime and require meaningful routines and opportunities for practice.

Children's literacy skills, especially the constrained skills, are expected to meet normative levels for their age group. Assessing these benchmarks allows one to ascertain where a child needs literacy training. The early literacy measures in this study assessed four key skills of early reading and writing, namely name writing, alphabet knowledge, phonological awareness, and print awareness. These skills can be found in various other early childhood literacy measures (e.g. Bowles et al., 2014; Moyle et al., 2013; Puranik et al., 2013).

\section{MEASUREMENT OF EARLY DIGITAL LITERACY}

Along with an increasing role of digital technology in children's lives, comes the call for literacy development that extends beyond the traditional areas of reading and writing. There is a need for survival skills in the digital era, or what is now known as digital literacy (Eshet, 2012). Digital literacy involves a complex set of component skills that include the ability to identify, understand, interpret, create, and communicate texts that are written, printed and digital (UNESCO, 2005). Neumann, Finger, and Neumann (2017) described emergent digital literacy as as the skills, knowledge, and attitudes which are the developmental precursors of digital literacy. Ng (2015) described digital literacy as "the integrated cognitive, technical, and social-emotional ability of an individual to competently use digital technologies across the various contexts of life" (p. 129).

Relatively little is known about the development of these precursors of digital literacy skills (Kennedy et al., 2012; Marsh, 2006). In this study, the measurement of early digital literacy skills 
is derived from Ng's (2015) distinction between a technical, cognitive, and socio-emotional dimensions. Following the dynamic trend of digital devices usage, the technical dimension is the most developed research focus in digital literacy for childhood education. The skills in the technical dimension revolves around the ability to operate digital technologies and their functional features. Most research has measured children's digital literacy by recording whether or not there was skilled usage of digital devices, such as computers (with internet) (Ba et al., 2002); or tablets and mobile phones (with apps) (Marsh, 2016; Neumann \& Neumann, 2017; Oakley et al., 2018; Ozturk \& Ohi, 2018). Most of these studies involved primary-school (6 - 10 years of age)

While the precise nature of children's experience with technology tools in early childhood is still in debate, NAEYC and Fred Rogers Center for Early Learning and Children's Media (2012) suggested that digital media should be used to enhance children's cognitive and social abilities in order to be able to strengthen the understanding of the appropriate use of digital media later in life. The technical skills required will always be changing along with the evolving digital devices, while the other dimensions relatively stays the same. Therefore, the present study did not assess technical skills development, but focused instead on skills development as far as the cognitive and social-emotional dimensions.

Measurement approach to Ng's (2015) cognitive and social-emotional dimensions of early digital literacy are still relatively absent although researchers other than $\mathrm{Ng}$ have argued for their relevance (Marsh, et al., 2018). The cognitive dimension involves critical thinking and multimodality. The representation afforded by digital technologies can be multimodal dominated by visuals $(\mathrm{Ng}, 2015)$. These become familiar modes of representation and are crucial for accessing information critically and creating knowledge (Beatty, 2013). The socio-emotional dimension involves communication and social skills. This dimension emphasizes the importance of understanding and protecting one's own safety and privacy while communicating and socializing digitally. The measures used in this study assessed these two dimensions of digital literacy.

\section{THE CURRENT STUDY}

The research presented employs a quasi-experimental design with three conditions. In the control condition, children engaged in regular literacy development activities, which revolved mainly around drill and practice activities for reading and writing. In the two experimental conditions, children engaged in structured activities embedded with storytelling or digital storytelling and structured activities relevant to the story. Two research questions were addressed:

- How does early literacy development in the two storytelling conditions compare with such development for the control condition?

- How does early digital literacy development in the two storytelling conditions compare with such development for the control condition? 
A previous study studied the same questions (Maureen et al, 2018). The present study involves a more extensive intervention. This intervention included six units spread over a six-week period, compared to three units in the previous study. This extended time for the intervention was made to address any possible novelty effect of the storytelling activities. In addition, it allowed us to investigate whether more prolonged exposure to structured storytelling activities would also yield as large a learning gain, as found in the previous study.

In relation to the first research question, it was predicted that the Storytelling condition (S) and the Digital Storytelling condition (DS) would provide stronger support than would the Control condition (C). No difference for literacy development was expected between the two experimental conditions. In relation to the second research question, the previous study explored the digital literacy development for all children in the study, across three classrooms. It was expected that the outcome would substantiate the previous, tentative finding of stronger outcomes for digital storytelling, followed by the storytelling condition, and then the control condition.

\section{METHOD}

The study was conducted in three classrooms from two public kindergartens in Indonesia. The 62 participants ( 30 girls and 32 boys) in this study were 5 - and 6-year-old children with an average age of 5.58 years $(S D=0.5)$. Intact classrooms were randomly assigned to conditions. This led to the following groups: Control $(N=18)$, Storytelling $(N=24)$, and Digital Storytelling $(N=20)$.

\section{Instructional materials}

The materials were six units of storytelling activities: My Name, My Body, My Hobby, My Friends, My Birthday, and My Senses. Each unit was conducted during one day once a week. These units revolved around common themes that are addressed in the beginning of the academic year during the time this study took place. Each unit had two or three objectives that aimed to contribute to early literacy or early digital literacy skills development. These objectives become the main lines in the storytelling and also in the follow up activities. The construction of the activities in the units was based on Gagné's events of instruction (Smith \& Ragan, 2005).

Each unit had a four-part structure: (a) circle time opening (30 min.), (b) (digital) storytelling (30 min.), (c) follow-up activities (60 min.) and (d) circle time closure (30 min.). The detailed set-up of a unit is illustrated with the theme of 'My Body'. The objectives of this unit were (a) recognizing own identity and (b) recognizing daily words related to body parts. Table 1 shows how (digital) storytelling and Gagné's events of instruction were blended in the unit. 
Table 1

An illustration of the blend between (digital) storytelling and Gagnés events of instruction

\begin{tabular}{|c|c|}
\hline Gagné's events of instructions & Classroom sessions \\
\hline \multicolumn{2}{|l|}{ Circle time - opening (30 min) } \\
\hline Gain attention & Engagement in morning routine \\
\hline Inform learners of the objectives & $\begin{array}{l}\text { Teacher tells the children about the theme and objective of } \\
\text { the day }\end{array}$ \\
\hline \multirow[t]{2}{*}{ Stimulate recall of prior learning } & Sing parts of body song \\
\hline & Trace own name on a health card \\
\hline \multicolumn{2}{|l|}{ (Digital) Storytelling (30 min) } \\
\hline \multirow[t]{2}{*}{ Present the content } & $\begin{array}{l}\text { Teacher tells the rules for the session and some identification } \\
\text { of the story }\end{array}$ \\
\hline & $\begin{array}{l}\text { Teacher tells the story or plays the digital story via a } \\
\text { projection device }\end{array}$ \\
\hline Provide learning guidance & $\begin{array}{l}\text { Teacher leads a discussion about the different parts of the } \\
\text { story and how it relate to the activities at the rest of the day }\end{array}$ \\
\hline \multicolumn{2}{|l|}{ Follow-up activities (60 min) } \\
\hline Elicit performance & Play with balls with name labels \\
\hline Provide feedback & Play with sets of doctor role play \\
\hline \multicolumn{2}{|l|}{ Circle time - closure (30 min) } \\
\hline Assess performance & Create bacteria monsters and present them to the class \\
\hline Enhance retention and transfer & $\begin{array}{l}\text { Teacher reviews the story and summarizes activities of the } \\
\text { day }\end{array}$ \\
\hline
\end{tabular}

\section{Instructional assessments}

\section{Early literacy measures}

The scoring in the Early Literacy test is based on a rubric with the following component skills: (1) Name writing (2) Recognizing uppercase letters, (3) Recognizing lowercase letters, (4) Identifying the initial sound of words, (5) Recognizing names in written form, (6) Recognizing daily words; scores could vary between 0 and 4 points (see Appendix A).

Name writing. Children's own names are often the first words they are taught to recognize and write (Dunsmuir \& Blatchford, 2004). Name writing skills is a developmental process that begins with prealphabetic forms, and involves print concepts, letter identification, letter reproduction (Puranik et al., 2011), and knowledge of letter-sound correspondence (Cardoso-Martins et al., 2011).

Assessment of this skill involved: first, a child was asked to write her/his first name at a booklet cover. If the child said that (s)he could not write it down, the examiner would show the prepared example. The child was rated depending on the level of help required and competence in this writing task (See Appendix A). 
Alphabet knowledge. Alphabet knowledge is a key of early literacy skill (Powell, Diamond, Bojczyk, \& Gerde, 2008). It can be defined as the ability to distinguish the shapes and names of the letters in the alphabet (Puranik, Petscher, \& Lonigan, 2014). There is an ongoing debate on what precedes the other and accordingly which component skill should be taught first. Some teachers prefer to begin with the uppercase because it is easier to distinguish the shapes of each letter (Bowles et al., 2014) while others prefer to start with lowercase because there are more lowercase letters in a common text. In this study, both uppercase and lowercase letters were tested with separate pages.

Assessment of this skill involved: First, the child was shown a single page with the 26 letters of the alphabet presented in scrambled sequence. Next, the experimenter pointed to each letter, and asked the child to name it. Responses were scored as correct, incorrect, or no response. More letters yielded more points.

Phonological awareness. Phonological awareness is an awareness of sounds in spoken words (Demont \& Gombert, 1996). Successful efforts to train phonological awareness have led to significant achievement differences in reading acquisition (Anthony \& Francis, 2005). In other studies, it has been measured, and consequently defined, by many different tasks. The common feature of these tasks is isolating single sounds from words (e.g. What is the first sound in "fish"?). Assessment of this skill involved: The stimulus material consisted of nineteen words from daily life, each consisting of two to three syllables. Each word was read aloud to a child who should then mention the first sound of that word. Before actual testing, the child was given two practice items to acquaint them to reproducing the sound rather than state the name of the letter. If the child failed to identify the initial sound of the first word, the next word would be asked. If the child did not get any sounds correct in the first 5 words, the assessment was discontinued.

Print awareness. Print awareness refers to the forms, conventions and functions of print (Justice \& Ezell, 2001). It includes conceptual knowledge about print forms, print concepts and book concepts. Print awareness is a skill that develops both naturally in time and through environmental factors (Çetin, 2014).

Assessment of this skill involved: The first feature was recognizing names in printed form, so the stimulus material was the name list of the children in the classroom. Each child was asked to point and state the name(s) they recognized. The more names stated correctly, the higher the score. The second stimulus material consisted of twenty words from daily life. The children would get a score depending on the number of words they could read.

This Early Literacy test was a slightly extended version of the test used in the previous study (Maureen et al., 2018). The only difference was that alphabet recognition was split into an item on lowercase and capital letters. In the present study, the Early Literacy test was also administered before and after the intervention. Reliability analyses using Cronbach's alpha showed good scores for both the pretest $(\alpha=0.91)$ and posttest $(\alpha=0.84)$.

\section{Early digital literacy measures}

The early digital literacy measures assessed prerequisite skills in cognitive and social-emotional dimensions of digital literacy. To our knowledge, the research literature has not yet devised 
assessment measures for these facets of digital literacy for kindergarten-aged children. The scoring of the Early Digital Literacy test itself is based on of a rubric with the following component skills: 1) Plan an event, (2) Read a picture, (3) Predict an event, (4) Recognize own identity, (5) State conversation rules, (6) Engage in a conversation (see Appendix B).

Cognitive skills. Critical and multimodal thinking are two relevant skills from the cognitive dimension in digital literacy development $(\mathrm{Ng}, 2015)$. In early childhood, critical thinking is supported by enhancing the children's ability to plan (Epstein, 2003) and to predict (BrosseauLiard, 2017). Multimodal thinking in early childhood includes the ability to 'read' a picture. These are three test items for the cognitive skills dimension. The first is planning an event. The second concerns the child's ability to identify a picture in a story book. The third feature is predicting an event based on a book illustration.

This skill assessment varied across the three item types. To assess event planning, the child was asked to tell his or her desires for the next birthday party. The presence of a particular type of information (e.g., what, who, where, when, how, why) in the child's response yielded a score of 1 point. The stimulus material in the second and third items was a flap book about a dog, Spot (Hill, 2005). To measure the ability to read a picture, the child was shown a picture from the book and asked to name the objects that were displayed. If the child could name 1-2 things from the picture, (s)he would be asked to make a picture-based inference (e.g., What do you think the story is about?) for a higher score. To measure the ability to predict, the experimenter would present a picture and ask the child to guess what might happen next. If the child couldn't give any prediction, the experimenter would give some clues (e.g., You said that you saw this and that, so what do you think happens on the next page?). The child got a higher score if ( $s$ )he could make a prediction without any clue.

Social-emotional skills. The social-emotional skills measured in digital literacy involved items that concerned the child's ability to communicate about his/herself to others through digital platforms ( $\mathrm{Ng}, 2015)$. In early childhood, an important aspect of this facet concerns gaining a sense of selfidentity (Marsh et al., 2005). For young children, the development of self-identity includes getting to know their own name, age, and gender. There are three test items for this competency. The first item concerns recognizing their own identity (including full name, age, and birthday). The second and third item concern conversations. Item two refers to the ability to mention rules or guidelines for holding a conversation. The third item measures the ability to apply the conversation rules when engaging in a 2-minute conversation.

Assessment of this skill involved: children were asked to introduce themselves. Each bit of information such as a name, age, date-month, and year of birth was awarded 1 point ( $\max 4$ ). For the second item, the child was asked to mention conversation rules. Each rule that was mentioned yielded 1 point $(\max 4)$ ). To assess the third item, the experimenter talked with the child for two minutes. The assessor would record when the child followed used any of four pre-defined conversation rules (i.e., maintains eye contact, waits for his/her turn to speak, asks and responds correctly, and stays on topic). Each rule that was followed yielded 1 point (max 4).

The Early Digital Literacy test was a modified version of the test used in the previous study (Maureen et al., 2018). For cognitive skills assessment, the item predicting an event replaced 
recalling an event. For social-emotional skills assessment, the item involving stating conversation rules was added. The previous study found satisfactory reliability for pretest $(\alpha=0.65)$ and posttest $(\alpha=0.87)$. In the present study, the Early Digital Literacy test was also administered before and after the intervention. Reliability analyses using Cronbach's alpha showed that the pretest was not reliable. This was presumed to be an effect of the novel nature of the items for the children. The intervention should help in this respect, and it did. There was a high reliability score on the posttest $(\alpha=0.84)$.

\section{Procedure}

The study consisted of three phases: pretest (Weeks 1-2), intervention (Week 3-8), and posttest (Weeks 9-11). In the pretest and posttest phases, a group of three to five children were brought into the reading room of the school where the experimenter and two research assistants were present. The experimenter and one research assistant would then assess each child individually. Administration of the Early Literacy test took 10-15 minutes for each child. The Early Digital Literacy test took 25-35 minutes per child. While testing was being done, the other children in the room engaged in play activities led by the second research assistant.

During the intervention phase, children in the control condition engaged in their regular, weekly literacy-oriented activities led by their classroom teacher with the experimenter present. The children in the two experimental conditions received one unit of storytelling activities or digital storytelling activities each week for a total of six weeks. These sessions were led by the experimenter with the teacher present.

\section{Data analysis}

The data from 9 (out of 62) children were removed from the data analysis. Seven children were removed because they had participated in fewer than five sessions of the storytelling units. Two other children were not able to complete all the tests. The dataset for the analyses comprised 53 children (16 in Control condition, 21 in the Storytelling condition, and 16 in the Digital Storytelling condition).

Tests on assumptions of normality of distribution and homogeneity of variance revealed violations for the Early Literacy test. For scores from this assessment, we therefore, report findings from non-parametric tests (i.e., the Kruskal-Wallis $\mathrm{H}$ test) followed by post hoc tests (i.e., the Mann-Whitney $U$ test). For scores from the Early Digital literacy test regular parametric tests (ANOVA) could be employed, followed by a Tukey HSD post hoc test. Testing was one-tailed for predicted improved effects in the intervention conditions, or otherwise were two-tailed, and Alpha was set at 0.05 . For effect size, we report the $r$ statistic (Cohen, 1988) and $r$ effects was classified as small (0.10 - 0.29), intermediate (0.30 - 0.49), and large (0.50 - higher).

\section{RESULTS}

In this section, findings are reported for the two research questions: (1) "How does early literacy development in the two storytelling conditions compare with such development for the control 
condition?". (2) "How does early digital literacy development in the two storytelling conditions compare with such development for the control condition?". It was predicted that children in the Storytelling condition and the Digital story telling conditions would have stronger scores on the Early Literacy measures than children in the Control condition. In addition, children in the Digital storytelling condition would have the strongest scores for measures of Early Digital literacy, followed by the Storytelling and Control conditions.

\section{Early literacy skills}

The findings for the Early Literacy Skills assessment at pretest and posttest are presented in Table 2. Mean scores of the participants in all three conditions were below the mid-scale value of 2 on the pretest. On the posttest, these scores for all three groups had improved, resulting in mean scores well above the mid-scale value of 2 . In addition, level of variability of children's posttest scores in each condition had reduced, as indicated by the standard deviations.

Table 2

Means (Standard Deviation) for early literacy skills tests by conditions

\begin{tabular}{l|cc|cc}
\hline Condition & \multicolumn{2}{|c|}{$\begin{array}{c}\text { Pretest } \\
\text { Mean }(S D)\end{array}$} & \multicolumn{2}{|c}{$\begin{array}{c}\text { Posttest } \\
\text { Mean (SD) }\end{array}$} \\
\hline Control $(n=16)$ & 1.56 & $(0.78)$ & 2.85 & $(0.42)$ \\
Storytelling $(n=21)$ & 1.44 & $(0.95)$ & 3.08 & $(0.85)$ \\
Digital Storytelling $(n=16)$ & 1.57 & $(1.00)$ & 3.43 & $(0.58)$ \\
Total $(n=53)$ & 1.51 & $(0.90)$ & 3.12 & $(0.69)$ \\
\hline
\end{tabular}

Note. Scored on a 0-4 point scale, 4 is the highest score.

Scores for the Early Literacy pretest did not differ between conditions, $H(53)=0.0168, p=0.558$. However, there was a statistically significant difference on the Early Literacy posttest, $H(53)=$ 8.739, $p=0.013$. Post hoc tests showed a statistically significant and large difference in the comparison of scores between Control and Storytelling condition, $U(37)=66.50, z=1.804, p=$ 0.0365 (one-sided), $r=0.51$. In addition there was a statistically significant and large difference in the comparison between the Control and Digital Storytelling condition, $U(32)=203.50, z=2.863$, $p=0.0015$ (one-sided), $r=0.50$. There was no difference between the Storytelling and Digital Storytelling condition, $U(37)=215.00, z=1.449, p=0.156$.

The boxplots for the Early Literacy assessment, pretest and posttest (Figure 1) further detail the learning development for each condition. The tinted areas in each box represent the middle $50 \%$ of the scores. The slightly thicker horizontal line in the box is the median. The top (or bottom) $25 \%$ of the scores are shown in the distance between the highest (or lowest) horizontal line and the highest (or lowest) edge of the tinted box. For the pretest scores, all tinted boxes overlap. For the posttest scores, only the tinted boxes of the Control and Digital Storytelling condition do not overlap. There is some overlap between the Control and Storytelling conditions and between the Storytelling and Digital Storytelling conditions. 


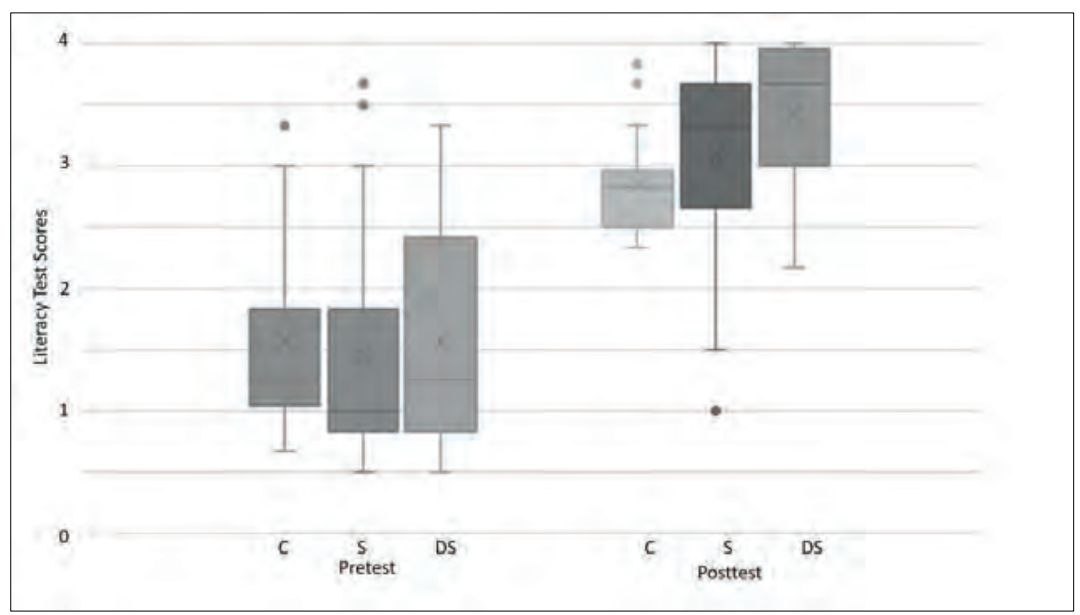

Figure 1. Boxplots (with $\mathrm{x}$ indicating the Mean) of the early literacy pretest and posttest scores by condition (C - control; S - Storytelling; DS - Digital Storytelling).

\section{Early digital literacy skills}

Table 3 shows findings of the pretest and posttest scores for Early Digital Literacy development. The results showed that the pretest scores in all three conditions were well below the midscale value of 2 . The mean posttest score was well above the midscale value. The variances, indicated by the standard deviations, were relatively low for pretests and posttests.

Table 3

Means (Standard Deviation) for the early digital literacy skills tests by condition

\begin{tabular}{lcccc}
\hline Condition & \multicolumn{2}{c}{$\begin{array}{c}\text { Pretest } \\
\text { Mean }(S D)\end{array}$} & \multicolumn{3}{c}{$\begin{array}{c}\text { Posttest } \\
\text { Mean }(S D)\end{array}$} \\
\hline Control $(n=16)$ & 1.49 & $(0.24)$ & 2.34 & $(0.32)$ \\
Storytelling $(n=21)$ & 1.60 & $(0.28)$ & 2.92 & $(0.56)$ \\
Digital Storytelling $(n=16)$ & 1.52 & $(0.21)$ & 3.04 & $(0.36)$ \\
Total $(n=53)$ & 1.54 & $(0.25)$ & 2.78 & $(0.53)$ \\
\hline
\end{tabular}

Note. scored on a 0-4 point scale, 4 is the highest score.

ANOVA showed that there were no statistically significant differences between conditions on the Early Digital Literacy pretest, $F(2,50)=1.008, p=0.372$. In contrast, a statistically significant difference was found on the posttest, $F(2,50)=11.479, p=0.00$. Post hoc tests showed that there was a statistically significant, and large, difference for the comparison between the Control and Storytelling condition, $p=0.001, r=0.66$; and also for the comparison between the Control and Digital Storytelling condition, $p<0.001, r=0.82$. The two experimental conditions did not differ significantly from each other, $p=0.693$. 
The boxplots for the Early Digital Literacy pretest and posttest (as shown in Figure 2) further detail the comparison between the conditions. For the pretest scores, the tinted boxes of the three conditions overlap each other. For the posttest scores, the tinted box of the Control condition does not overlap with those of the Storytelling or Digital Storytelling condition. In contrast, there is overlap between experimental conditions and the median scores of these conditions are similar.

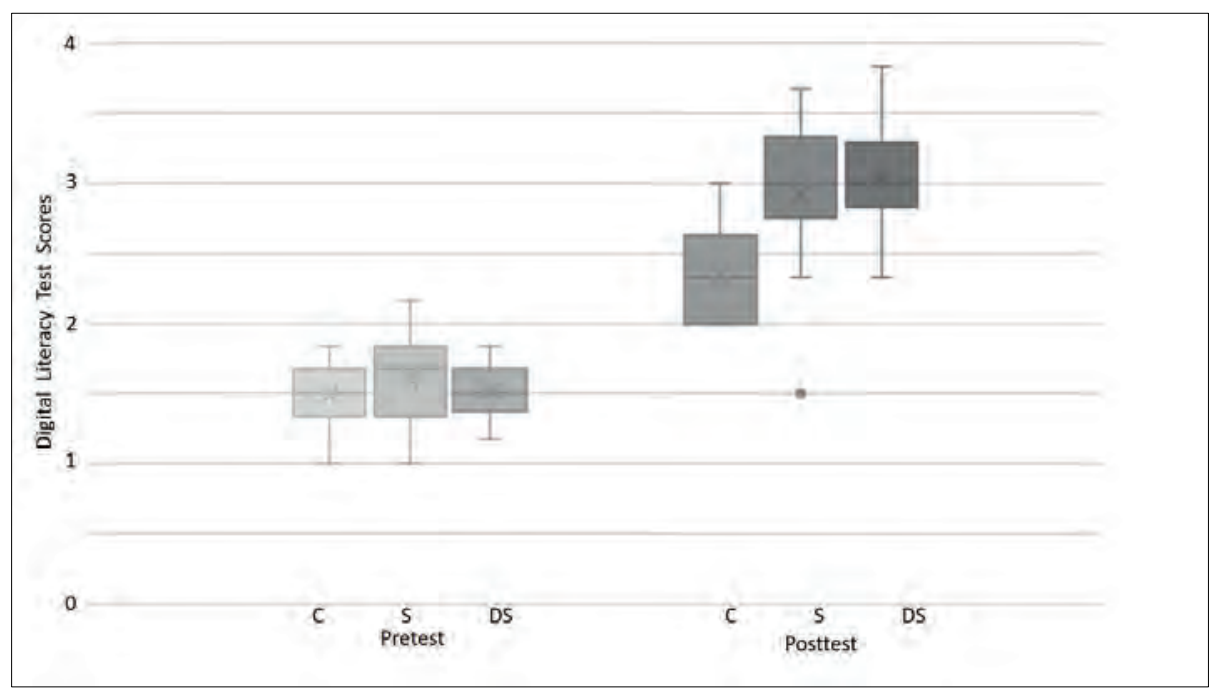

Figure 2. Boxplots (with $\mathrm{x}$ indicating the Mean) of the early digital literacy pre and posttest scores by conditions (C - Control; S - Storytelling; CS - Digital Storytelling).

\section{DISCUSSION}

In this research, the processes of storytelling were blended with Gagné's nine events of instruction (Smith \& Ragan, 2005) in delivery of play-based activities to support early literacy and early digital literacy. Storytelling has long been related to literacy development. In this intervention, events were structured for learning through specific design of teachers' and children's activities. Embedding storytelling in activities (re)introduces natural forms of instruction for early childhood education. The study investigated whether these approaches could effectively support change in early literacy and early digital literacy learning outcomes.

\section{Storytelling activities for literacy development}

The present study found stronger literacy development for the two experimental conditions compared with the control group. The difference was statistically significant and the effect size showed strong change. This finding replicates the outcome of a previous study with a shorter intervention period (Maureen et al., 2018). The finding supports the choice for a design approach that revolves around storytelling in which explicit instructions and opportunities for practice are interleaved. 
The storytelling session presented the teacher with explicit instructions to introduce the children to the code-based characteristics of written language (Zubrick et al., 2015) and to provide repetition and context to enhance words comprehension (Wright \& Neuman, 2014). These were complemented with opportunities for practice in the chosen follow-up activities in which the children actively explored the related letters, words, and sounds. The coupling fits recommendations for high quality literacy instruction (Justice et al., 2008). In addition, it concurs with the view that literacy development is driven by meaning-making (Tolentino \& Lawson, 2017).

Though there were no significant differences between the experimental conditions. The digital storytelling condition showed slightly stronger gains compared to the storytelling condition. This can perhaps be explained by the fact that the use of digital elements can contribute to making abstract content more understandable and motivating for young children (e.g., Boerma et al., 2016).

\section{Storytelling activities for digital literacy development}

The study found stronger digital literacy development in the experimental conditions than in the control condition. As for literacy development, the difference was statistically significant. The finding substantiated the tentative outcome that was reported in an earlier study (Maureen et al., 2018). No difference was found between the two experimental conditions.

The absence of a difference between the two experimental conditions may be due to the comparable activities across these conditions. An important and shared foundation in both approaches is the presence of follow-up activities that stimulated the children to develop their understanding of stories (Porras González, 2010). These play-based activities were incorporated within the broader framework of a storytelling approach. Through participation in storytelling experiences, in this case, by listening to a story and discussing about it afterward, children could acquire a sense of story, about how it begins and ends, and how the social element of language enables stories to evolve. These activities support the children in constructing a story model or schema that affords them with opportunities to explain certain events in a story and make predictions of events that may come to pass.

\section{Limitations and future research}

The present study offers some insight into the instructional design and the measurement of a broad spectrum of literacy skills in early childhood education. These research findings would benefit from further research into the use of these self-developed measurement instruments to establish validity with other available standardized tests of literacy.

The study was also limited by the fact that the storytelling activities were led by the experimenter while regular activities in the control condition were taught by the classroom teacher. During the activities, the teacher or experimenter served as a teaching assistant or vice versa. This choice was based on the view that the regular program in the control condition should be as realistic as possible. 


\section{CONCLUSIONS}

We consider that effective storytelling hinges on five key features of stories (i.e., setting, theme, characters, plot, and conflict) from which children acquire a story schema that supports later reading comprehension. While effective digital storytelling also requires attention to personalization, a specific point of view, a dramatic question, emotional content to personalize the content, power of voice, a soundtrack, economy of presentation, and pacing (Robin, 2008). When these ideas were applied in the design of the units for this intervention, they were not tested separately or against each other. This challenge can be taken up in future studies, as is the suggestion that child variations in motivation and engagement with digital and traditional storytelling may also be important factors to consider.

Overall, the present study has provided empirical evidence that a framework in which a blend of structured instruction with storytelling and play-based activities, both in oral and digital forms, can effectively support children's literacy and digital literacy development. 


\section{APPENDIX A}

\section{Scoring rubric for early literacy assessment}

\begin{tabular}{|c|c|c|c|c|c|c|c|}
\hline & Key Skill & Description & 0 point & 1 point & 2 points & 3 points & 4 points \\
\hline 1 & $\begin{array}{l}\text { Name } \\
\text { writing }\end{array}$ & $\begin{array}{l}\text { Write first } \\
\text { name } \\
\text { (/nick } \\
\text { name) }\end{array}$ & $\begin{array}{l}\text { Needs } \\
\text { help to } \\
\text { write first } \\
\text { name }\end{array}$ & $\begin{array}{l}\text { Writes first } \\
\text { name with } \\
\text { a model } \\
\text { with some } \\
\text { errors }\end{array}$ & $\begin{array}{l}\text { Writes } \\
\text { correctly } \\
\text { first name } \\
\text { with a } \\
\text { model }\end{array}$ & $\begin{array}{l}\text { Writes first } \\
\text { name } \\
\text { correctly } \\
\text { without a } \\
\text { model }\end{array}$ & $\begin{array}{l}\text { Writes first } \\
\text { name } \\
\text { correctly } \\
\text { without a } \\
\text { model, } \\
\text { capitalizing } \\
\text { first letter }\end{array}$ \\
\hline 2 & $\begin{array}{l}\text { Alphabet } \\
\text { knowledge } \\
\text { (1) }\end{array}$ & $\begin{array}{l}\text { Recognize } \\
\text { capital } \\
\text { letters }\end{array}$ & $\begin{array}{l}\text { Needs } \\
\text { help to } \\
\text { recognize } \\
\text { any letters }\end{array}$ & $\begin{array}{l}\text { 1-5 letters } \\
\text { recognized }\end{array}$ & $\begin{array}{l}\text { 6-15 letters } \\
\text { recognized }\end{array}$ & $\begin{array}{l}16-25 \\
\text { letters } \\
\text { recognized }\end{array}$ & $\begin{array}{l}26 \text { letters } \\
\text { recognized }\end{array}$ \\
\hline 3 & $\begin{array}{l}\text { Alphabet } \\
\text { knowledge } \\
(2)\end{array}$ & $\begin{array}{l}\text { Recognize } \\
\text { lowercase } \\
\text { letters }\end{array}$ & $\begin{array}{l}\text { Needs } \\
\text { help to } \\
\text { recognize } \\
\text { any letters }\end{array}$ & $\begin{array}{l}\text { 1-5 letters } \\
\text { recognized }\end{array}$ & $\begin{array}{l}\text { 6-15 letters } \\
\text { recognized }\end{array}$ & $\begin{array}{l}16-25 \\
\text { letters } \\
\text { recognized }\end{array}$ & $\begin{array}{l}26 \text { letters } \\
\text { recognized }\end{array}$ \\
\hline 4 & $\begin{array}{l}\text { Phonological } \\
\text { awareness }\end{array}$ & $\begin{array}{l}\text { Identify the } \\
\text { initial } \\
\text { sound of } \\
\text { words }\end{array}$ & $\begin{array}{l}\text { Needs help } \\
\text { to identify } \\
\text { the initial } \\
\text { sound of a } \\
\text { word }\end{array}$ & $\begin{array}{l}1-6 \text { words } \\
\text { identified }\end{array}$ & $\begin{array}{l}\text { 7-12 words } \\
\text { identified }\end{array}$ & $\begin{array}{l}13-18 \\
\text { words } \\
\text { identified }\end{array}$ & $\begin{array}{l}19 \text { words } \\
\text { identified }\end{array}$ \\
\hline 5 & $\begin{array}{l}\text { Print } \\
\text { awareness } \\
\text { (1) }\end{array}$ & $\begin{array}{l}\text { Recognize } \\
\text { names in } \\
\text { written } \\
\text { form }\end{array}$ & $\begin{array}{l}\text { Needs } \\
\text { help to } \\
\text { recognize } \\
\text { any friend's } \\
\text { name on } \\
\text { the } \\
\text { children's } \\
\text { attendance } \\
\text { list }\end{array}$ & $\begin{array}{l}1 \text { name } \\
\text { recognized }\end{array}$ & $\begin{array}{l}\text { 2-3 names } \\
\text { recognized }\end{array}$ & $\begin{array}{l}\text { 4-5 names } \\
\text { recognized }\end{array}$ & $\begin{array}{l}6 \text { names } \\
\text { recognized }\end{array}$ \\
\hline 6 & $\begin{array}{l}\text { Print } \\
\text { awareness } \\
\text { (2) }\end{array}$ & $\begin{array}{l}\text { Recognize } \\
\text { daily words }\end{array}$ & $\begin{array}{l}\text { Needs } \\
\text { help to } \\
\text { recognize } \\
\text { any word }\end{array}$ & $\begin{array}{l}1-5 \text { words } \\
\text { recognized }\end{array}$ & $\begin{array}{l}\text { 6-12 words } \\
\text { recognized }\end{array}$ & $\begin{array}{l}13-19 \\
\text { words } \\
\text { recognized }\end{array}$ & $\begin{array}{l}20 \text { words } \\
\text { recognized }\end{array}$ \\
\hline
\end{tabular}




\section{APPENDIX B}

\section{Scoring rubric for early digital literacy assessment}

\begin{tabular}{|c|c|c|c|c|c|c|c|}
\hline$\#$ & Skill & Description & 0 point & 1 point & 2 points & 3 points & 4 points \\
\hline 1 & $\begin{array}{l}\text { Cognitive } \\
(1)\end{array}$ & $\begin{array}{l}\text { Plan an } \\
\text { event }\end{array}$ & $\begin{array}{l}\text { No } \\
\text { response } \\
\text { given }\end{array}$ & $\begin{array}{l}\text { Contains } \\
\text { information } \\
\text { about: what }\end{array}$ & $\begin{array}{l}\text { Contains } \\
\text { information } \\
\text { about: what } \\
\text { and where/ } \\
\text { when/who }\end{array}$ & $\begin{array}{l}\text { Contains } \\
\text { information } \\
\text { about: what, } \\
\text { who, where, } \\
\text { when ( } 3 \text { or } \\
\text { 4) }\end{array}$ & $\begin{array}{l}\text { Contains } \\
\text { information } \\
\text { about: what, } \\
\text { who, where, } \\
\text { when, how, } \\
\text { why }\end{array}$ \\
\hline 2 & $\begin{array}{l}\text { Cognitive } \\
(2)\end{array}$ & $\begin{array}{l}\text { Read a } \\
\text { picture }\end{array}$ & $\begin{array}{l}\text { Needs } \\
\text { help to } \\
\text { mention } \\
\text { anything } \\
\text { seen in a } \\
\text { picture }\end{array}$ & $\begin{array}{l}\text { Mentions 1- } \\
2 \text { things } \\
\text { seen from } \\
\text { picture(s) } \\
\text { with clues }\end{array}$ & $\begin{array}{l}\text { Mentions 1- } \\
2 \text { things } \\
\text { seen in } \\
\text { picture with } \\
\text { clues } \\
\text { Infers story } \\
\text { of a picture }\end{array}$ & $\begin{array}{l}\text { Mentions 3- } \\
4 \text { things } \\
\text { seen from } 2 \\
\text { pictures } \\
\text { Infers the } \\
\text { story of } 2 \\
\text { pictures }\end{array}$ & $\begin{array}{l}\text { Mentions 3-4 } \\
\text { things seen } \\
\text { from } 3 \\
\text { pictures } \\
\text { Infers the } \\
\text { story of } 3 \\
\text { pictures }\end{array}$ \\
\hline 3 & $\begin{array}{l}\text { Cognitive } \\
\text { (3) }\end{array}$ & $\begin{array}{l}\text { Predict an } \\
\text { event }\end{array}$ & $\begin{array}{l}\text { Makes an } \\
\text { off-topic } \\
\text { prediction } \\
\text { or gives } \\
\text { no } \\
\text { response }\end{array}$ & $\begin{array}{l}\text { Makes } \\
\text { prediction of } \\
\text { logical } \\
\text { sequence of } \\
\text { picture, given } \\
\text { details or } \\
\text { clues }\end{array}$ & $\begin{array}{l}\text { Makes } \\
\text { prediction of } \\
\text { logical } \\
\text { sequence of } \\
\text { picture }\end{array}$ & $\begin{array}{l}\text { Makes } \\
\text { prediction of } \\
\text { logical } \\
\text { sequence of } \\
2 \text { pictures }\end{array}$ & $\begin{array}{l}\text { Makes } \\
\text { prediction of } \\
\text { logical } \\
\text { sequence of } \\
3 \text { pictures }\end{array}$ \\
\hline 4 & $\begin{array}{l}\text { Social } \\
\text { emotional } \\
(1)\end{array}$ & $\begin{array}{l}\text { Recognize } \\
\text { own identity }\end{array}$ & $\begin{array}{l}\text { Needs } \\
\text { help to } \\
\text { mention } \\
\text { own full } \\
\text { name }\end{array}$ & $\begin{array}{l}\text { Mentions } \\
\text { own full } \\
\text { name }\end{array}$ & $\begin{array}{l}\text { Mentions } \\
\text { own full } \\
\text { name } \\
\text { own age }\end{array}$ & $\begin{array}{l}\text { Mentions } \\
\text { own full } \\
\text { name clearly } \\
\text { own age } \\
\text { own } \\
\text { birthday (d- } \\
\text { m-y) }\end{array}$ & $\begin{array}{l}\text { Mentions } \\
\text { own full } \\
\text { name clearly } \\
\text { own age } \\
\text { own birthday } \\
\text { (d-m-y) }\end{array}$ \\
\hline 5 & $\begin{array}{l}\text { Social- } \\
\text { emotional } \\
(2)\end{array}$ & $\begin{array}{l}\text { Mention } \\
\text { conversation } \\
\text { rules }\end{array}$ & $\begin{array}{l}\text { Gives no } \\
\text { response }\end{array}$ & $\begin{array}{l}\text { Mentions } 1 \\
\text { conversation } \\
\text { rule }\end{array}$ & $\begin{array}{l}\text { Mentions } 2 \\
\text { conversation } \\
\text { rules }\end{array}$ & $\begin{array}{l}\text { Mentions } 3 \\
\text { conversation } \\
\text { rules }\end{array}$ & $\begin{array}{l}\text { Mentions } 4 \\
\text { conversation } \\
\text { rules }\end{array}$ \\
\hline 6 & $\begin{array}{l}\text { Social- } \\
\text { emotional } \\
\text { (3) }\end{array}$ & $\begin{array}{l}\text { Engage in a } \\
\text { conversation }\end{array}$ & $\begin{array}{l}\text { Passively } \\
\text { responds } \\
\text { to ques- } \\
\text { tions }\end{array}$ & $\begin{array}{l}\text { Needs } \\
\text { reminders to } \\
\text { follow all } \\
\text { rules of } \\
\text { conversation }\end{array}$ & $\begin{array}{l}\text { Needs } \\
\text { reminders to } \\
\text { follow some } \\
\text { of rules of } \\
\text { conversation }\end{array}$ & $\begin{array}{l}\text { Needs } \\
\text { reminders to } \\
\text { follow a few } \\
\text { rules of } \\
\text { conversation }\end{array}$ & $\begin{array}{l}\text { Follows all } \\
\text { rules of } \\
\text { conversation: } \\
\text { maintains } \\
\text { eye contact } \\
\text { waits for } \\
\text { his/her turn } \\
\text { to speak } \\
\text { asks correctly } \\
\text { (stays in } \\
\text { topic) } \\
\text { responds } \\
\text { correctly } \\
\text { (stays in } \\
\text { topic) }\end{array}$ \\
\hline
\end{tabular}




\section{REFERENCES}

Anthony, J. L., \& Francis, D. J. (2005). Development of phonological awareness. Current Directions in Psychological Science, 14(5), 255-259. https://doi.org/10.1111/j.0963-7214.2005.00376.x

Ba, H., Tally, W., \& Tsikalas, K. (2002). Investigating children's emerging digital literacies. The Journal of Technology, Learning, and Assessment, 1(4), 1-47.

Barber, J. F. (2016). Digital storytelling: New opportunities for humanities scholarship and pedagogy. Cogent Arts \& Humanities, 3(1), 1181037. https://doi.org/10.1080/23311983.2016.1181037

Beatty, N. A. (2013). Cognitive visual literacy: From theories and competencies to pedagogy. Art Documentation, 32(1), 33-42. https://doi.org/10.1086/669987

Bežilová, V. (2019). The effect of storytelling on longer vocabulary retention. Contemporary Research in Education and English Language Teaching, 1(1), 57-62.

Boerma, I. E., Mol, S. E., \& Jolles, J. (2016). Reading pictures for story comprehension requires mental imagery skills. Frontiers in Psychology, 7, 1630-1630. https://doi.org/10.3389/fpsyg.2016.01630

Boltman, A., \& Druin, A. (2003). Children's storytelling technologies: Differences in elaboration and recall. https://drum.lib.umd.edu/handle/1903/1169

Bowles, R. P., Pentimonti, J. M., Gerde, H. K., \& Montroy, J. J. (2014). Item response analysis of uppercase and lowercase letter name knowledge. Journal of Psychoeducational Assessment, 32(2), 146-156. https://doi.org/10.1177/0734282913490266

Brosseau-Liard, P. É. (2017). The roots of critical thinking: Selective learning strategies in childhood and their implications. Canadian Psychology, 58(3), 263-270. https://doi.org/10.1037/cap0000114

Brown, C. S. (2014). Language and literacy development in the early years: Foundational skills that support emergent readers. The Language and Literacy Spectrum, 24, 35-49.

Cardoso-Martins, C., Mesquita, T. C. L., \& Ehri, L. (2011). Letter names and phonological awareness help children to learn letter-sound relations. Journal of Experimental Child Psychology, 109(1), 25-38. https://doi.org/10.1016/j.jecp.2010.12.006

Çetin, Ö. Ş. (2014). The investigation of pre-school children's print awareness and skills for writing preparation. Journal of Theoretical Educational Science, 7(3), 342-360. htpps://doi.org/10.5578/keg.7036

Chang, H. Y., Park, E. J., Yoo, H. J., Lee, J. W., \& Shin, Y. (2018). Electronic media exposure and use among toddlers. Psychiatry investigation, 15(6), 568-573.

https://doi.org/10.30773/pi.2017.11.30.2

Cohen, J. (1988). Statistical power analysis for the behavioral sciences (2nd ed.). Taylor \& Francis Inc.

Cooper, P. M. (2005). Literacy learning and pedagogical purpose in Vivian Paley's 'storytelling curriculum'. Journal of Early Childhood Literacy, 5(3), 229-251.

https://doi.org/10.1177/1468798405058686

Cremin, T., Flewitt, R., Swann, J., Faulkner, D., \& Kucirkova, N. (2018). Storytelling and story-acting: Co-construction in action. Journal of Early Childhood Research, 16(1), 3-17. https://doi.org/10.1177/1476718×17750205 
Demont, E., \& Gombert, J. E. (1996). Phonological awareness as a predictor of recoding skills and syntactic awareness as a predictor of comprehension skills. British Journal of Educational Psychology, 66(3), 315-332. https://doi.org/10.1111/j.2044-8279.1996.tb01200.x

Dunsmuir, S., \& Blatchford, P. (2004). Predictors of writing competence in 4- to 7-year-old children. British Journal of Educational Psychology, 74(3), 461-483. https://doi.org/10.1348/0007099041552323

Epstein, A. S. (2003). How planning and reflection develop young children's thinking skills. Young Children, 58(5), 28-36.

Eshet, Y. (2012). Thinking in the digital era: A revised model for digital literacy. Issues in Informing Science and Information Technology, 9, 267-276. https://doi.org/10.28945/1621

Gallant, P. A. (2009). Kindergarten teachers speak out: “Too much, too soon, too fast!”. Reading Horizons, 49(3), 201-220.

Golbeck, S. L. (2001). Psychological perspectives on early childhood education: Reframing dilemmas in research and practice. Routledge.

Hill, E. (2005). Spot goes on holiday - translated version to Bahasa Indonesia. Gramedia Pustaka Utama.

Justice, L. M., \& Ezell, H. K. (2001). Word and print awareness in 4-year old children. Child Language Teaching and Therapy, 17(3), 207-225. https://doi.org/10.1177/026565900101700303

Justice, L. M., Mashburn, A., Hamre, B., \& Pianta, R. (2008). Quality of language and literacy instruction in preschool classrooms serving at-risk pupils. Early Childhood Research Quarterly, 23(1), 51-68. https://doi.org/10.1016/j.ecresq.2007.09.004

Kennedy, E., Dunphy, E., Dwyer, B., McPhillips, T., O’Connor, M., Hayes, G., \& Shiel, G. (2012). Literacy in early childhood and primary education (3-8 years) [Research Report No. 15]. National Council for Curriculum and Assessment https://www.ncca.ie/media/2137/literacy_in_early_childhood_and_primary_education_38_years.pdf

Kolucki, M., \& Lemish, D. (2011). Communicating with children. United Nations Children’s Fund (UNICEF).

Lisenbee, P. S., \& Ford, C. M. (2018). Engaging students in traditional and digital storytelling to make connections between pedagogy and children's experiences. Early Childhood Education Journal, 46(1), 129-139. https://doi.org/10.1007/s10643-017-0846-x

Lucarevschi, C. R. (2016). The role of storytelling in language learning: A literature review. Working Papers of Linguistics Circle of the University of Victoria, 26, 24-44.

Marcon, R. A. (1999). Differential impact of preschool models on development and early learning of inner-city children: A three-cohort study. Developmental Psychology, 35(2), 358-375. https://doi.org/10.1037/0012-1649.35.2.358

Marsh, J. (2006). Emergent media literacy: Digital animation in early childhood. Language and Education, 20(6), 493-506. https://doi.org/10.2167/le660.0

Marsh, J. (2016). The digital literacy skills and competences of children of pre-school age. Media Education: Studies and Research, 7(2), 197-214. https://doi.org/10.14605/MED721603 
Marsh, J., Brooks, G., Hughes, J., Ritchie, L., Roberts, S., \& Wright, K. (2005). Digital beginnings: Young children's use of popular culture, media and new technologies. (Report of the Young People's Use of Popular Culture, Media and New Technologies Studies). The University of Sheffield http://www.digitalbeginnings.shef.ac.uk/DigitalBeginningsReport.pdf

Marsh, J., Plowman, L., Yamada-Rice, D., Bishop, J., Lahmar, J., \& Scott, F. (2018). Play and creativity in young children's use of apps. British Journal of Educational Technology, 49(5), 870-882. https://doi.org/10.1111/bjet.12622

Maureen, I. Y., van der Meij, H., \& de Jong, T. (2018). Supporting literacy and digital literacy development in early childhood education using storytelling activities. International Journal of Early Childhood, 371-389. https://doi.org/10.1007/s13158-018-0230-z

Mayer, R. (2009). Multimedia Learning. Cambridge University Press. https://doi.org/10.1017/СВO9780511811678

McConnell, S., \& Wackerle-Hollman, A. (2016). Can we measure the transition to reading? General outcome measures and early literacy development from preschool to early elementary grades. AERA Open, 2(3), 2332858416653756. https://doi.org/10.1177/2332858416653756

McGill-Franzen, A. (2006). Kindergarten literacy: Matching assessment and instruction in kindergarten. Scholastic.

Miller, J. L., Paciga, K. A., Danby, S., Beaudoin-Ryan, L., \& Kaldor, T. (2017). Looking beyond swiping and tapping: Review of design and methodologies for researching young children's use of digital technologies. Cyberpsychology, 11(3:6). https://doi.org/10.5817/CP2017-3-6

Missall, K. N., Carta, J. J., McConnell, S. R., Walker, D., \& Greenwood, C. R. (2008). Using individual growth and development indicators to measure early language and literacy. Infants \& Young Children, 21(3), 241-253. https://doi.org/10.1097/01.iyc.0000324553.85187.dc

Moyle, M. J., Heilmann, J., \& Berman, S. S. (2013). Assessment of early developing phonological awareness skills: A comparison of the preschool individual growth and development indicators and the phonological awareness and literacy screening-PreK. Early Education and Development, 24(5), 668-686. https://doi.org/10.1080/10409289.2012.725620

NAEYC., \& Fred Rogers Center for Early Learning and Children's Media. (2012). Technology and interactive media as tools in early childhood programs serving children from birth through age 8 [Position Statement]. https://www.naeyc.org/resources/topics/technology-andmedia

Neumann, M. M., Finger, G., \& Neumann, D. L. (2017). A conceptual framework for emergent digital literacy. Early Childhood Education Journal, 45(4), 471-479. https://doi.org/10.1007/s10643016-0792-z

Neumann, M. M., \& Neumann, D. L. (2017). The use of touch-screen tablets at home and pre-school to foster emergent literacy. Journal of Early Childhood Literacy, 17(2), 203-220. https://doi.org/10.1177/1468798415619773

Ng, W. (2015). Digital literacy: The overarching element for successful technology integration. In W. $\mathrm{Ng}$, New digital technology in education: Conceptualizing professional learning for educators (pp. 125-145). Springer International Publishing.

Nicolopoulou, A., McDowell, J., \& Brockmeyer, C. (2006). Narrative play and emergent literacy. In D. Singer, R. Golinkoff, \& K. Hirsh-Pasek (Eds.) Play = Learning (pp. 124-144). Oxford. 
Oakley, G., Wildy, H., \& Berman, Y. (2018) Multimodal digital text creation using tablets and openended creative apps to improve the literacy learning of children in early childhood classrooms. Journal of Early Childhood Literacy. https://doi.org/10.1177/1468798418779171

Ozturk, G., \& Ohi, S. (2018). Understanding young children's attitudes towards reading in relation to their digital literacy activities at home. Journal of Early Childhood Research, 16(4), 393-406. https://doi.org/10.1177/1476718×18792684

Paris, S. G. (2005). Reinterpreting the development of reading skills. Reading Research Quarterly, 4O(2), 184-202. https://doi.org/10.1598/RRQ.40.2.3

Peck, J. (1989). Using storytelling to promote language and literacy development. The Reading Teacher, 43(2), 138-141.

Phillips, L. (2000). Storytelling - The seeds of children's creativity. Australian Journal of Early Childhood, 25(3), 1-5. https://doi.org/10.1177/183693910002500302

Porras González, Nohora Inés. (2010). Teaching English through stories: A meaningful and fun way for children to learn the language. Profile Issues in Teachers 'Professional Development, 12(1), 95-106. http://www.scielo.org.co/scielo.php?script=sci_arttext\&pid=S165707902010000100007\&lng=en\&tlng=en

Powell, D. R., Diamond, K. E., Bojczyk, K. E., \& Gerde, H. K. (2008). Head start teachers’ perspectives on early literacy. Journal of Literacy Research, 40(4), 422460. https://doi.org/10.1080/10862960802637612

Puranik, C. S., Lonigan, C. J., \& Kim, Y. S. (2011). Contributions of emergent literacy skills to name writing, letter writing, and spelling in preschool children. Early Childhood Research Quarterly, 26(4), 465-474. https://doi.org/10.1016/j.ecresq.2011.03.002

Puranik, C. S., Petscher, Y., \& Lonigan, C. J. (2013). Dimensionality and reliability of letter writing in 3to 5-year-old preschool children. Learning and Individual Differences, 28, 133-141. https://doi.org/10.1016/j.lindif.2012.06.011

Puranik, C. S., Petscher, Y., \& Lonigan, C. J. (2014). Learning to write letters: Examination of student and letter factors. Journal of Experimental Child Psychology, 128, 152-170. https://doi.org/10.1016/j.jecp.2014.07.009

Ritchey, K. D. (2008). The building blocks of writing: Learning to write letters and spell words. Reading and Writing, 21(1), 27-47. https://doi.org/10.1007/s11145-007-9063-0

Robin, B. R. (2008). Digital storytelling: A powerful technology tool for the 21st century classroom. Theory Into Practice, 47(3), 220-228. https://doi.org/10.1080/00405840802153916

Roslan, R. (2008). The use of stories and storytelling in primary science teaching and learning. Studies in Education, 12, 79-89.

Smith, P. L., \& Ragan, T. J. (2005). Instructional design (3rd ed.). Wiley.

Stevens, R. J., Van Meter, P., \& Warcholak, N. D. (2010). The effects of explicitly teaching story structure to primary grade children. Journal of Literacy Research, 42, 159-198. https://doi.org/10.1080/10862961003796173 
Teale, W. H., Whittingham, C. E., \& Hoffman, E. B. (2018). Early literacy research, 2006-2015: A decade of measured progress. Journal of Early Childhood Literacy. https://doi.org/10.1177/1468798418754939

Tolentino, E. P., \& Lawson, L. (2017). 'Well, we're going to kindergarten, so we're gonna need business cards!': A story of preschool emergent readers and writers and the transformation of identity. Journal of Early Childhood Literacy, 17(1), 47-68. https://doi.org/10.1177/1468798415605570

UNESCO (2005). Education for all: Literacy for life (EFA Global Monitoring Report no. ED2005/PI/01). https://unesdoc.unesco.org/ark:/48223/pf0000141639

UNESCO (2018). Building tomorrow's digital skills - what conclusions can we draw from international comparative indicators? (Report no. ED-2018/WS/7).

https://unevoc.unesco.org/go.php?q=Online+library\&lang=en\&null=\&null=\&akt=id\&st=\&qs $=6099$

Wood, E., \& Hedges, H. (2016). Curriculum in early childhood education: Critical questions about content, coherence, and control. The Curriculum Journal, 27(3), pp. 387-405. https://doi.org/10.1080/09585176.2015.1129981

Whitehurst, G. J., \& Lonigan, C. J. (1998). Child development and emergent literacy. Child Development, 69(3), 848-872. https://doi.org/10.1111/j.1467-8624.1998.tb06247.x

Wright, T. S., \& Neuman, S. B. (2014). Paucity and disparity in kindergarten oral vocabulary instruction. Journal of Literacy Research, 46(3), 330357. https://doi.org/10.1177/1086296X14551474

Zubrick, S. R., Taylor, C. L., \& Christensen, D. (2015). Patterns and predictors of language and literacy abilities 4-10 years in the longitudinal study of Australian children. PloS One, 10(9), e0135612-e0135612. https://doi.org/10.1371/journal.pone.0135612 


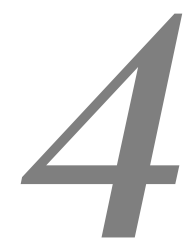

Designing storytelling activities for early literacy development 


\begin{abstract}
This study reports on the effectiveness of a series of activities over a 6-week period that aimed to enhance early literacy development. The activities were grounded on a storytelling approach. There were three conditions in the study. In the control condition, regular literacy development activities took place. In one experimental condition, the series of activities included oral storytelling. In the other experimental condition, the activities included digital storytelling. Participants were 59 4- to 5-year-old children from three kindergarten classrooms. Children were assessed before and after the intervention for their early literacy skills development using 2 standardized tests and 1 non-standardized test. The results on the standardized tests showed that there was equally strong literacy development in all conditions. On the non-standardized test, the children in the experimental conditions did better than the control group. The discussion draws attention to the specific qualities of the intervention for early literacy development, and the benefits of testing this development with a mixture of standardized and dedicated tests.
\end{abstract}

Keywords: storytelling, instruction, early literacy, early childhood 


\section{INTRODUCTION}

Development of early literacy skills is critical for children's learning and later school achievement (Bennett et al., 2002). Early childhood studies have drawn attention to various categories of skills that constitute early literacy. Generally, the foundational content in early literacy skills consists of oral language comprehension, print awareness and phonological skills (Rohde, 2015). In kindergarten, this generally is provided in the form of a teacher-led delivery of literacy instructions followed by drill-and-practice exercises (Zettler-Greeley et al., 2018). A number of longitudinal studies have found that these practices significantly contribute to the children's literacy skills development (Piasta et al., 2010).

However, notwithstanding these positive findings there remains a divergence of viewpoints about the appropriate structure of such instructions within early childhood education. That is, other research argued that this context should not rely on too formalized conventional instructional approaches, since they could not always assure long term accomplishment (Bodrova, 2008). We should instead adopt an instructional design approach that fits children's natural way of learning, as well as provide well-planned systematic guidance for early literacy skills development (HirshPasek et al., 2009).

The present study took on the challenge of developing a series of activities for early literacy skills development in the latter way. The design resulted in structured storytelling approach that consisted of a 6-week intervention. This approach, in which storytelling activities were embedded in Gagné's nine events of instruction, was tested for its effectiveness. Earlier research (Maureen et al., 2018, 2020) already proved the effectiveness of this approach for literacy skills development as measured by non-standardized tests. The present study also administered standardized tests to benchmark the progress made with the approach.

\section{STORYTELLING AND DIGITAL STORYTELLING}

The activity of storytelling points to a social and cultural practice oriented to the act of telling and sharing stories (Roig et al., 2018). Throughout history sharing stories has been one of the most common means of knowledge being passed on from generation to generation. Storytelling is probably one of the oldest forms of teaching. In early classrooms, a storytelling session, where a teacher tells a story to the children, can capture the children's interest and motivation, and by connecting it to their everyday life and prior experience it can support sense-making.

In kindergarten, storytelling is mostly conducted independently from other instructional activities. It is predominantly used as a moment of relaxation in between main tasks or as an attention-getter at the beginning of the day. It is mostly employed as a complementary activity in early education classrooms (Roslan, 2008; Wells, 1986). While storytelling can indeed be relaxing and entertaining, it also has the advantage of communicating narrative structures. They involve the elements of setting, theme, characters, plot, and conflict that allow storytelling to provide a model of speech, a context for learning, and a way to expand imagination, which all contribute to literacy development. 
There is a considerable body of research on the effects of storytelling interventions on children's story-related abilities such as story comprehension and the acquisition of story structures like diction, grammatical structure, and content of the story (Fekonja-Peklaj et al., 2010; WesselPowell et al., 2016). Many research investigated its effects on general or second language development (e.g. Abasi \& Soori, 2014; Flynn, 2016) and social emotional development (e.g. Cekaite \& Björk-Willén, 2018; Sunday, 2018). However, the contribution of a storytelling approach to early literacy skills development is hardly ever investigated.

One prominent exception is Vivian Paley's research (Cooper, 2005). Paley designed the Storytelling Curriculum that incorporates children to tell stories and to act them out. The holistic nature of the storytelling curriculum is evident in the learning goals that it promotes in many areas of development, from language development to social-emotional development (Cooper, 2005) including some literacy skills (Nicolopoulou et al., 2015). Two critical aspects in Paley's 'storytelling curriculum are prior knowledge and group size. For the curriculum to be effectively employed, the children need to have a basic understanding of narrative structure and teaching should be done with a relatively small number of children in a group (Flewitt et al., 2016). Especially the latter can be an obstacle in countries where kindergarten classrooms may consist of over 15 children. This study proposed to design storytelling activities that is appropriate to children at the beginning of the school year (without any prerequisite knowledge on narrative structure) and applicable to a relatively large group. Here the children listen to stories and engage in playful activities that related to the story lines.

Assuming that children have an innate love of stories, it is also noteworthy that today's children are increasingly involved in storytelling interactions across multiple media platforms. Introducing storytelling activities in early childhood education may therefore benefit from not only bringing property-related story features like pictures and puppets, but also digital technology yielding a form of digital storytelling. Digital storytelling combines the art of telling stories with a mixture of digital media, including pictures and narration (Robin, 2016).

Regular stories can be adapted to the digital field with the same benefits, and possibly even more advantages because digital stories have different elements (Ryan, 2004). Digital storytelling adopts a specific point of view, contains a dramatic question, and has emotional content to personalize the content of the story. Moreover, in digital storytelling the gift of voice, power of soundtrack, economy, and pacing can be attended to in design to personalize the delivery of the story. Most digital stories are short and between two to ten minutes long. They are many different kinds of digital stories, but one major type is the personal narrative (Robin, 2008). This type fits the common themes in the beginning of academic year in kindergarten, therefore it is employed in the present study.

There is a growing interest in digital storytelling for young learners. Most research on this issue concentrates on the kindergarten teachers (Yuksel-Arslan et al., 2016) or older children (Sadik, 2008). The usage of digital storytelling to enhance literacy development in early childhood education is, to our knowledge, yet to be explored. 


\section{EARLY LITERACY MEASUREMENTS}

Literacy has been broadly defined as the capability related to reading, writing, communication and oral language both in print- and digital-based (Kennedy et al., 2012). Literacy begins early in life and is a continuous and developmental process (Banerjee et al., 2016). Therefore, the foundation must be addressed in early childhood education. Early literacy development should focus on the skills that are the precursors to conventional forms of reading and writing (Missall et al., 2008).

Early literacy include constrained and unconstrained components (Paris, 2005). Constrained components are also known as technical or decoding skills. These include knowledge of letters, phonics, and concepts of print. These skills are necessary, but not sufficient, for literacy development. They are best taught and measured systematically as part of a comprehensive language and literacy program. Unconstrained components are meaning-based skills that include competency in oral language, vocabulary, and comprehension. These skills are developed across a person's lifetime and require meaningful routines and opportunities for practice.

Children's literacy skills, especially the constrained ones, are expected to meet normative levels for their age group. Assessing these benchmarks allows one to ascertain where a child needs literacy training. Considerable attention has been given to instrument development for measuring constrained skills. An example of a popular standardized test is the Dynamic Indicators of Basic Early Literacy (DIBELS; Kamii \& Manning, 2005). DIBELS focuses on decoding skills such as phonological awareness, alphabet knowledge, and early reading.

DIBELS uses formal, standardized strategies in its measurements, meaning that the test is administered under controlled circumstances in highly structured environments. Standardization allows control over factors that can influence the findings, such as how directions are given, how teachers should respond to children's questions, and how teachers score children' responses. However, an important drawback of such assessments situations is that young children may have difficulty meeting the demands of the situation (National Research Council, 2000).

To help fill the need for a reliable, research-based screening measure for use with 3- to- 5-yearold children, Whitehurst and Lonigan developed the Get Ready to Read! (GRTR) screening tool in conjunction with the National Center for Learning Disabilities (NCLD; Whitehurst, 2001). The goal for development was to create a brief, user-friendly measure that had strong concurrent relations to more comprehensive measures for early literacy skills including print knowledge, letter knowledge, and phonology awareness.

Both DIBELS and GRTR are assessment methods that use formal strategies. There has been some critique on these approaches for evaluating young children's skill (Langford, 2010). One argument that has been raised is young children's limited test-taking abilities to assess competence. Another concern is the possible distractions that interfere with accurate measurement of capabilities. This critique has led to the support the use of informal strategies for measuring early literacy skills. These are flexible forms of assessment in which the measurement can be adjusted according to a particular context or the child that is assessed. For instance, when the measurement involves a checklist or portfolio, the teacher may have considerable freedom in how to interpret the data. This is also an important weakness of informal assessment strategies 
since the teacher may be prejudiced, or hold certain stereotypes that can influence judgement (Brown \& Rolfe, 2005).

In our view, assessment is best done with a carefully selected set of informal and formal strategies that assess specific characteristics over several designated periods of time, and in many different contexts. Accordingly, this study has adapted content from standardized tests to the local curriculum, language, and culture, and conducted the assessments in settings that are comfortable, familiar, non-threatening, and of interest to the child. There is evidence that assessments in such settings better enable children to show what they know, what they can do, and what they are experiencing (National Research Council, 2000).

\section{THE CURRENT STUDY}

The research design was quasi-experimental with three conditions. In the control condition (C), the children engaged in regular literacy development activities, that revolved mainly around drill and practice activities in reading and writing. In the two experimental conditions, the children engaged in structured storytelling (S) or digital storytelling (DS) activities.

The main research question is: "How well do the series of literacy activities in kindergarten classrooms support early literacy skills development?" The tested prediction is that the experimental conditions yield more skills development than the control. There are two subquestions. The first one concerns the question how well the three conditions contribute to higher scores on standardized literacy tests. The second one is the question how well the three conditions contribute to higher scores on dedicated early literacy test.

\section{METHOD}

\section{Participants}

The study was conducted in three classrooms from two public kindergartens. The 59 participants (28 girls and 31 boys) in this study were 4- and 5-year old children with an average age of 5.12 years $(S D=0.34)$. Intact classrooms were randomly assigned to conditions. This led to the following groups: Control $(N=15)$, Storytelling $(N=18)$, and Digital Storytelling $(N=26)$.

\section{Instructional materials}

The materials were six units of storytelling activities: "My Name", My Body", "My Hobby", "My Friends, "My Birthday", and "My Senses". The units revolved around common themes in the schools' curriculum that are addressed in the beginning of the academic year, when the experiments took place.

In the experimental condition, the construction of the activities in the units was based on Gagné's events of instruction (Smith \& Ragan, 2005). Each unit had two or three objectives that aim to contribute to literacy skills development. These objectives become the main ideas in each storyline and in the follow up activities in the experimental conditions. A unit consisted of a four- 
part structure: (a) circle time opening (30 min.), (b) (digital) Storytelling (30 min.), (c) Follow-up activities (60 min.) and (d) circle time closure (30 min.). Within each unit, a storytelling and a digital storytelling is prepared for each condition. The mainline story is similar for both experimental conditions but the delivery methods are different. In the storytelling condition, the teacher would be the one who tells the story. In the digital storytelling condition, the teacher plays the pre-recorded storytelling on the classroom screen. The follow-up activities for both experimental conditions are the same. The detailed set-up of a unit is illustrated with the theme of "My Hobby". The objectives of this unit were (a) recognizing daily words related to hobby in written form and (b) having conversation about hobby. Table 1 shows how (digital) storytelling and Gagné's events of instruction were blended in the unit.

Table 1

An illustration of the blend between (digital) storytelling and Gagné's events of instruction

\begin{tabular}{ll}
\hline Gagné's events of instructions & Classroom sessions \\
\hline Circle time - opening (30 $\mathrm{min})$ & \\
Gain attention & Engagement in morning routine \\
Inform learners of the objectives & $\begin{array}{l}\text { Teacher tells the children about the theme and objective of the } \\
\text { day }\end{array}$ \\
Stimulate recall of prior learning & $\begin{array}{l}\text { Make a hobby booklet } \\
\text { Arrange conversation rules poster }\end{array}$ \\
\hline
\end{tabular}

\section{(Digital) storytelling (30 $\mathrm{min})$}

Present the content

Teacher tells the rules for the session and some identification of the story

Teacher tells the story or plays the digital story via a projection device

Provide learning guidance Teacher leads a discussion about how the story begin and end and the different parts of the story and how it relates to the activities at the rest of the day

\section{Follow-up activities (60 $\mathrm{min})$}

Elicit performance

Provide feedback
1) Matching game: hobby \& equipment (game with rules)

2) Conduct "What's your hobby?" survey (dramatic play) Note: Children may choose which activity they will do first. They have to experience both activities.

Teacher interacts with children to provide support and feedback

\section{Circle time - closure $(30 \mathrm{~min})$}

Assess performance Review the hobby-survey results

Enhance retention and transfer
Teacher reviews the story and summarizes activities of the day 
In the control condition, the children had the regular, weekly literacy-oriented program within the similar topics. Other than the opening routines in the morning and closing routines in the afternoon, the two main activities in the program are: reading and writing practice. Reading practice includes two activities, small-group reading and pretend reading. During small-group reading, the teacher assists 3 to 5 children to practice reading a group of words on the blackboard for ten minutes. The teacher spells each letter and reads each word a few times. The children will have to repeat what the teacher says. When the teacher engages in small group reading, the other children are encouraged to engage in pretend reading activity. In this activity, the children can select a book and then "read" or "play" with the book individually or with friends, in the corner of the classroom. Writing practice is the activity where the children practice writing by tracing and writing letters and words on worksheets prepared by the teacher. This activity is mostly done in classic arrangement where the teacher provides examples and models how to write alphabet and words to the whole classroom followed by the children tracing and or writing on the worksheets. In this study, the experimenter lead as the main teacher in all conditions while the classroom teacher present as the assistant.

\section{Assessment instruments}

\section{The Early Literacy Assessment Test (ELA Test)}

The ELA test assessed four key skills of early reading and writing, namely name writing, alphabet knowledge, phonological awareness, and print awareness. These skills can be found in various other early childhood literacy measures (e.g. Bowles et al., 2014; Fielding-Barnsley, 1997; Moyle et al., 2013; Puranik et al., 2013). The responses to the test were scored with a rubric; scores could vary between 0 and 4 points (see table 2).

The ELA test was the similar one used in the previous study (Maureen et al., 2020; see appendix 1). In the previous study, good reliability (Cronbach's alpha) scores were obtained from both pretest $(\alpha=0.91)$ and posttest $(\alpha=0.84)$. In the present study, the ELA test was also administered before and after the intervention. Reliability analyses using showed good scores for both the pretest $(\alpha=0.77)$ and posttest $(\alpha=0.86)$. 
Table 2

Scoring rubric for early literacy assessment test

\begin{tabular}{|c|c|c|c|c|c|c|c|}
\hline & Key Skill & Description & 0 point & 1 point & 2 points & 3 points & 4 points \\
\hline 1 & $\begin{array}{l}\text { Name } \\
\text { writing }\end{array}$ & $\begin{array}{l}\text { Write first } \\
\text { name } \\
\text { (/nick } \\
\text { name) }\end{array}$ & $\begin{array}{l}\text { Needs help } \\
\text { to write } \\
\text { first name }\end{array}$ & $\begin{array}{l}\text { Writes } \\
\text { first name } \\
\text { with a } \\
\text { model } \\
\text { with some } \\
\text { errors }\end{array}$ & $\begin{array}{l}\text { Writes } \\
\text { correctly first } \\
\text { name with a } \\
\text { model }\end{array}$ & $\begin{array}{l}\text { Writes first } \\
\text { name } \\
\text { correctly } \\
\text { without a } \\
\text { model }\end{array}$ & $\begin{array}{l}\text { Writes first } \\
\text { name } \\
\text { correctly } \\
\text { without a } \\
\text { model, } \\
\text { capitalizing } \\
\text { first letter }\end{array}$ \\
\hline 2 & $\begin{array}{l}\text { Alphabet } \\
\text { knowledge } \\
1\end{array}$ & $\begin{array}{l}\text { Recognize } \\
\text { capital } \\
\text { letters }\end{array}$ & $\begin{array}{l}\text { Needs help } \\
\text { to recognize } \\
\text { any letters }\end{array}$ & $\begin{array}{l}\text { 1-5 letters } \\
\text { recognized }\end{array}$ & $\begin{array}{l}\text { 6-15 letters } \\
\text { recognized }\end{array}$ & $\begin{array}{l}16-25 \\
\text { letters } \\
\text { recognized }\end{array}$ & $\begin{array}{l}26 \text { letters } \\
\text { recognized }\end{array}$ \\
\hline 3 & $\begin{array}{l}\text { Alphabet } \\
\text { knowledge } \\
2\end{array}$ & $\begin{array}{l}\text { Recognize } \\
\text { lowercase } \\
\text { letters }\end{array}$ & $\begin{array}{l}\text { Needs help } \\
\text { to recognize } \\
\text { any letters }\end{array}$ & $\begin{array}{l}\text { 1-5 letters } \\
\text { recognized }\end{array}$ & $\begin{array}{l}\text { 6-15 letters } \\
\text { recognized }\end{array}$ & $\begin{array}{l}16-25 \\
\text { letters } \\
\text { recognized }\end{array}$ & $\begin{array}{l}26 \text { letters } \\
\text { recognized }\end{array}$ \\
\hline 4 & $\begin{array}{l}\text { Phonolog- } \\
\text { ical } \\
\text { awareness }\end{array}$ & $\begin{array}{l}\text { Identify the } \\
\text { initial } \\
\text { sound of } \\
\text { words }\end{array}$ & $\begin{array}{l}\text { Needs help } \\
\text { to identify } \\
\text { the initial } \\
\text { sound of a } \\
\text { word }\end{array}$ & $\begin{array}{l}1-6 \text { words } \\
\text { identified }\end{array}$ & $\begin{array}{l}\text { 7-12 words } \\
\text { identified }\end{array}$ & $\begin{array}{l}\text { 13-18 } \\
\text { words } \\
\text { identified }\end{array}$ & $\begin{array}{l}19 \text { words } \\
\text { identified }\end{array}$ \\
\hline 5 & $\begin{array}{l}\text { Print } \\
\text { awareness } \\
1\end{array}$ & $\begin{array}{l}\text { Recognize } \\
\text { names in } \\
\text { written } \\
\text { form }\end{array}$ & $\begin{array}{l}\text { Needs help } \\
\text { to recognize } \\
\text { any friend's } \\
\text { name on } \\
\text { the child- } \\
\text { ren's atten- } \\
\text { dance list }\end{array}$ & $\begin{array}{l}1 \text { name } \\
\text { recognized }\end{array}$ & $\begin{array}{l}\text { 2-3 names } \\
\text { recognized }\end{array}$ & $\begin{array}{l}\text { 4-5 names } \\
\text { recognized }\end{array}$ & $\begin{array}{l}6 \text { names } \\
\text { recognized }\end{array}$ \\
\hline 6 & $\begin{array}{l}\text { Print } \\
\text { awareness } \\
2\end{array}$ & $\begin{array}{l}\text { Recognize } \\
\text { daily words }\end{array}$ & $\begin{array}{l}\text { Needs help } \\
\text { to recognize } \\
\text { any word }\end{array}$ & $\begin{array}{l}\text { 1-5 words } \\
\text { recognized }\end{array}$ & $\begin{array}{l}\text { 6-12 words } \\
\text { recognized }\end{array}$ & $\begin{array}{l}13-19 \\
\text { words } \\
\text { recognized }\end{array}$ & $\begin{array}{l}20 \text { words } \\
\text { recognized }\end{array}$ \\
\hline
\end{tabular}

\section{Standardized test - Get Ready to Read (GRTR)}

The GRTR includes 20 multiple-choice items in which the child is shown four visual clues and is asked to respond to a question about them by the experimenter. The items are intended to assess the domains of print knowledge (13 items covering print concepts, letter knowledge, and early writing) and phonological awareness ( 7 items). Print knowledge items require the child either to identify letters and sounds or to identify which of four pictures contains a word or letters. For example, item 4 requires the child to find the picture that shows a word among four different pictures of objects. Phonological awareness items require the child either to manipulate sounds in a way that forms a word and then to identify the picture represented by the word, or to identify which of four pictures rhymes with or begins with the same sound as a stimulus word. For 
example, item 18 requires the child to blend together "pen" and "guin" and choose which of four pictures depicts a penguin.

In this study, the GRTR was translated into the local language and adapted culturally to suit the condition of the children. Six items changed in this test. The changes either involved textual translation (e.g., "SOUP" became "SUP"), or replacement of pictures for culturally appropriate pictures (e.g. a "figure skating" picture was replaced by a "shoes" picture). The changes never concerned the correct answer. All changes have been made without any change on the concept being assessed.

Administration of the GRTR was as follows: First, a sample item was asked to make sure that the child understood the instructions. Next, the child was presented a page with 4 pictures. The experimenter asked the question, and the child answered by pointing to one of the four pictures. For example, for the first item, children are presented with illustrations of a book positioned in four different ways, and the experimenter asks, "These are pictures of a book. Find the one that shows the back of the book." For this measure, only correct answers are summed. The pretestposttest correlation coefficients for this test was $r=0.87$. It demonstrates the stability of the test scores between two time points (Cole et al., 2011).

\section{Standardized test - LNF - DIBELS}

For measuring the alphabet knowledge in this study, DIBELS Letter Naming Fluency (LNF) $6^{\text {th }}$ edition was used. It is a standardized, individually administered test appropriate for children younger than 6 years old. Children are presented with a page of upper-and lower-case letters arranged in a random order and are asked to name as many letters as they can within one minute. As it also has a standardized administration, this test was conducted following the directions in administration and for scoring (Good \& Kaminski, 2002).

Administration of this test was as follows: there were two sheets prepared for this test, one for the child and another one for the experimenter as the scoring sheet). The child was shown the page, and then the experimenter gave the standardized instruction: "Here are some letters; Tell me the names of as many letters as you can; When I say "begin", start here (point to first letter), and go across the page"; Point to each letter and tell me the name of that letter; If you come to a letter you don't know I'll tell it to you; Put your finger on the first letter; Ready, begin." The experimenter started the stopwatch, then at the end of 1 minute, placed a bracket ( ] ) after the last letter named and say, "Stop." If the child did not get any correct letter names within the first 10 letters (1 row), the task was discontinued.

\section{Procedure}

The study consisted of three phases: pretests (week 1-3), intervention (week 3-8), and posttests (week 9-11). Pretests phase consisted of two parts. The first part was the standardized tests where the tests were done individually (one-on-one). Administration of the standardized tests took 13 minutes for each child. During the administration of the self-developed tests, a group of three to five children gathered in the reading room of the school where the experimenter and two research assistants were present. Administration of the Early Literacy test was done 
individually (one-on-one) and took 10-15 minutes for each child. While testing was being done, the other children in the room engaged in activities led by the other research assistant.

During the intervention phase, the children in the control condition engaged in their weekly literacy-oriented activities led by the experimenter while their classroom teacher present. The activities in the program are using drill and practice method, for example, reading and writing practice sessions. The children in the two experimental conditions received one unit of storytelling, or digital storytelling, activities each week for a total of six weeks. These sessions were led by the experimenter with the teacher present. The posttests were administered after the intervention. Administration of these tests was the same as in pretesting.

\section{Data analysis}

Nine of the 59 children failed to complete one or more of the pretests or posttests ( 2 children) or attended less than 5 units ( 7 children). Only the complete data-set of 50 children will be reported. For Literacy tests, assumptions on normality of distribution and homogeneity of variance revealed violations for pretest and posttest scores. Therefore, we report the findings from non-parametric tests (i.e., Kruskal Wallis $\mathrm{H}$ test). Significant findings were followed by post hoc tests (i.e., Mann Whitney U test).

\section{RESULTS}

\section{DIBELS - Letter Naming Fluency}

Table 3 presents the results of Letter Naming Fluency (LNF) test from the DIBELS. These mean scores showed that the overall scores of the children in all three conditions at pretest and posttest were below $25 \%$ of the whole score. To compare the growth between conditions, the effect size and the learning gain of each condition are included in the table.

Table 3

Means, SD, effect sizes, and learning gain of DIBELS-LNF results

\begin{tabular}{lccccc}
\hline Condition & \multicolumn{2}{c}{$\begin{array}{c}\text { Pretest } \\
\text { Mean }(S D)\end{array}$} & $\begin{array}{c}\text { Posttest } \\
\text { Mean }(S D)\end{array}$ & $\begin{array}{c}\text { Effect } \\
\text { Size (d) }\end{array}$ & $\begin{array}{c}\text { Learning } \\
\text { Gain }(S D)\end{array}$ \\
\hline Control $(n=14)$ & 8.85 & $(7.66)$ & $42.42(32.13)$ & 1.40 & $33.57(24.93)$ \\
Storytelling $(n=14)$ & 5.42 & $(5.14)$ & $30.21(24.86)$ & 1.38 & $22.64(19.91)$ \\
Digital Storytelling $(n=22)$ & 4.90 & $(6.41)$ & $38.45(28.03)$ & 1.65 & $33.55(23.79)$ \\
\hline
\end{tabular}

Note. scored on a 0-120 point score, 120 is the highest score.

The scores on the DIBELS-LNF pretest, $H(50)=2.934, p=0.231$, and posttest, $H(50)=1.672, p=$ 0.434 , did not differ between conditions. The correlation (spearman rho) between the pretest and posttest is strongly positive, $p=0.83$ showing that the test has a strong internal validity. The boxplots for the DIBELS-LNF result (Figure 1) provide a visual presentation of the learning gains in all conditions. The shaded areas in each box represent the mid $50 \%$ of the scores. The shaded boxes are overlapped each other confirming that there was no significance difference between the 
learning gains. The horizontal line in the box is the median score of each condition. It showed that the median of the control condition is slightly higher than that of the other experimental conditions. Nevertheless, the DS showed the largest effect size among all conditions (see Table 3).

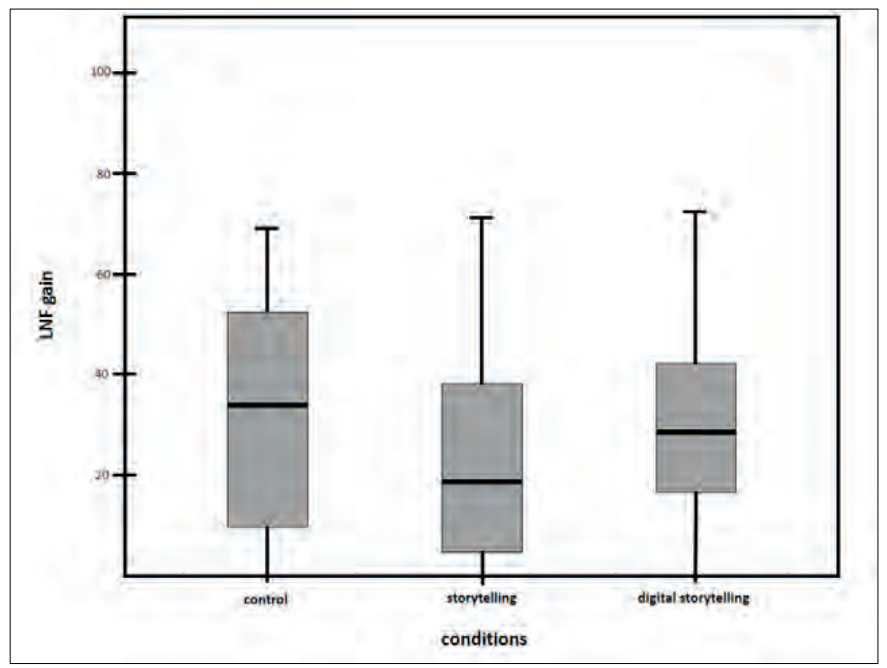

Figure 1. Boxplot for the LNF learning gain for each condition.

\section{Get Ready to Read (GRTR)}

Table 4 displays the mean item sores, standard deviation, effect sizes, and the learning gain for the GRTR test. The mean scores showed that the pretest scores of the participants in all three conditions were already reach $50 \%$ of the full score. In addition, there were moderate levels of variance of the results. The scores on the GRTR pretest, $H(50)=1.75, p=0.417$, and posttest, $H(50)=0.316, p=0.854$, did not differ between conditions. The correlation between the pretest and posttest is strongly positive, $p=0.84$, showing that the test has a strong internal validity. Furthermore, the DS showed the largest effect size among all conditions.

Table 4

Means, SD, effect sizes, and learning gain of GRTR result

\begin{tabular}{lcccc}
\hline Condition & $\begin{array}{c}\text { Pretest } \\
\text { Mean }(S D)\end{array}$ & $\begin{array}{c}\text { Posttest } \\
\text { Mean (SD) }\end{array}$ & $\begin{array}{c}\text { Effect Size } \\
\text { (d) }\end{array}$ & $\begin{array}{c}\text { Learning } \\
\text { Gain (SD) }\end{array}$ \\
\hline Control $(n=14)$ & $11.14(3.08)$ & $13.64(3.49)$ & 0.76 & $2.50(0,76)$ \\
Storytelling $(n=14)$ & $10.14(3.59)$ & $13.64(2.80)$ & 1.08 & $3.50(1,78)$ \\
Digital Storytelling $(n=22)$ & $9.59(3.77)$ & $13.63(2.36)$ & 1.28 & $4.04(2,33)$ \\
\hline
\end{tabular}

Note. scored on a 0-20 point score, 20 is the highest score.

There is also no significant difference in learning gain of the GRTR result. The boxplots in Figure 2 provide a visual presentation of GRTR learning gains in all conditions. The shaded areas in each box represent the mid $50 \%$ of the scores. The shaded boxes are overlapped each other confirming that 
there was no significance difference between the learning gains. The parallel sizes of the $\mathrm{S}$ and DS boxes, despite of the slightly different median, indicate that the distribution of the scores in these two experimental conditions are similar. The whiskers, top or bottom, represent scores outside the middle $50 \%$ (i.e. the lower $25 \%$ of scores and the upper $25 \%$ of scores). No upper whisker visible for the boxplot of the control condition means the upper quartile, the maximum score, is equal to the median. The boxplot for the DS condition has higher median and longer top whisker. It conveys that there are more children who have higher learning gains than the lower ones.

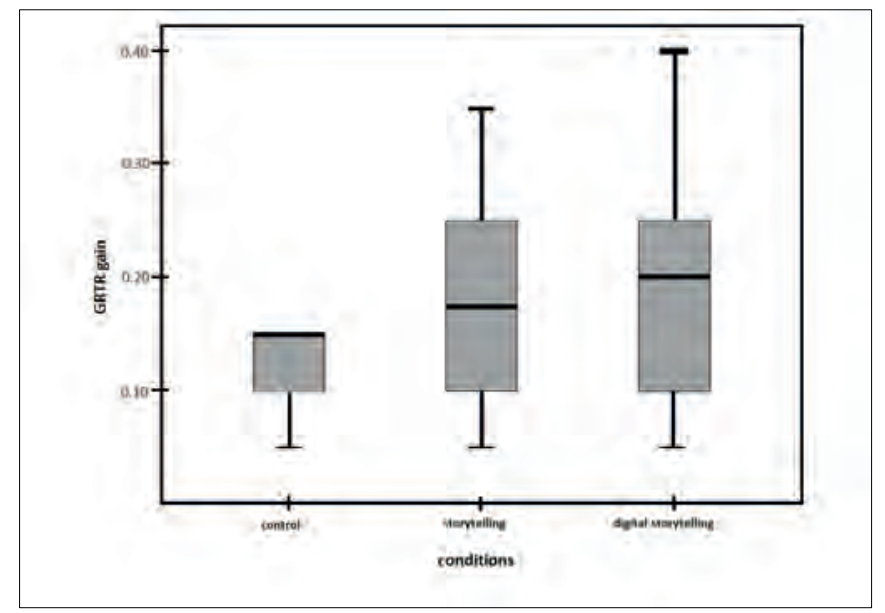

Figure 2. Boxplot for the GRTR learning gain for each condition.

\section{Early literacy assessment test}

Table 5 displays the findings for the self-developed ELA test. These mean scores showed that the pretest scores were below the mid-scale value of 2 . In addition, there were moderate levels of variance in both pretest and posttest mean scores.

Table 5

Means, SD, and learning gain of for ELA test by conditions

\begin{tabular}{lcccccc}
\hline Condition & \multicolumn{2}{c}{$\begin{array}{c}\text { Pretest } \\
\text { Mean }(S D)\end{array}$} & \multicolumn{2}{c}{$\begin{array}{c}\text { Posttest } \\
\text { Mean }(S D)\end{array}$} & \multicolumn{3}{c}{$\begin{array}{c}\text { Learning } \\
\text { Gain }(S D)\end{array}$} \\
\hline Control $(n=14)$ & 1.32 & $(0.70)$ & 2.55 & $(0.43)$ & 1.23 & $(0.52)$ \\
Storytelling $(n=14)$ & 1.32 & $(0.54)$ & 3.18 & $(0.46)$ & 1.86 & $(0.62)$ \\
Digital Storytelling $(n=22)$ & 1.35 & $(0.68)$ & 3.26 & $(0.66)$ & 1.91 & $(0.59)$ \\
Total $(n=50)$ & 1.33 & $(0.64)$ & 3.04 & $(0.62)$ & 1.71 & $(0.64)$ \\
\hline
\end{tabular}

Note. Scored on a 0-4 point scale, 4 is the highest score.

The scores on the early Literacy pretest did not differ between conditions, $H(50)=0.119, p=0.942$. In contrast, there was a statistically significant difference on the Literacy posttest, $H(50)=13.275$, $p=0.001$. Post hoc tests showed that there were statistically significant and large differences for 
the comparisons between the Control and Storytelling conditions and between the Control and Digital Storytelling conditions, respectively $U(28)=33, z=3.016, p=0.003, r=0.56 ; U(36)=55.5$, $z=3.211, p=0.001, r=0.53$. There was no difference between the two experimental conditions, $U(36)=118.50, z=1.164, p=0.244$.

The boxplots for the learning gain of the results, shown in Figure 3., showed that the shaded boxes of the control and experimental conditions are slightly overlapped. The median scores of the experimental conditions are higher than the median scores of the control condition.

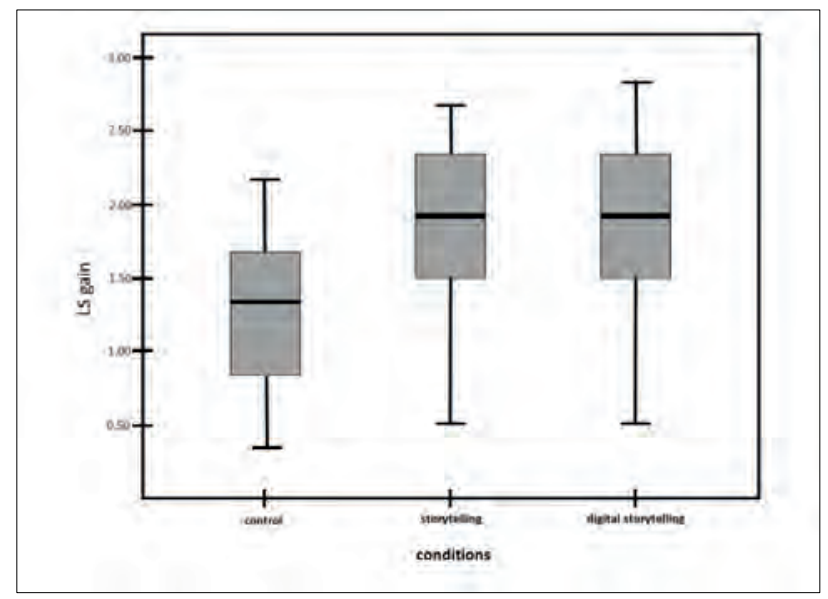

Figure 3. Boxplot for the LS learning gain for each condition.

\section{CONCLUSION AND DISCUSSION}

In order to support literacy development in early childhood education in a way that is appropriate for the children, a set of activities were designed that combined a storytelling approach and the framework of Gagné's events of instructions. The storytelling activities were designed to provide an appropriate structure for literacy instruction in early classroom. The story connected the instructions and play-based activities, serving as a common thread that conveyed the main aim of the activities and kept the children's interest. The present study aimed to determine how well the storytelling activities could support early literacy skills development on three different tests.

The LNF Dibels results showed no significant difference between all conditions at pretest and posttest scores. When we explored learning gains, there was also no difference between the conditions. In addition, the analyses showed that the children in the control condition achieved a slightly higher gain than in the experimental condition. A possible explanation for this might be that the children in the control condition were given direct instruction on memorizing and practicing the alphabet while in the children in the experimental conditions spent less time and engaged differently with issues concerning learning the alphabet. This finding seems to be consistent with other research that has found that explicitly teaching letter names, sounds, and written symbols will support the children's mastery of alphabet knowledge (Bedard et al., 2018; Jones et al., 2013). Nevertheless, the fact that there was no significant difference between 
conditions, and the finding that the effect sizes were strong in all conditions also showed that the storytelling activities, either digital or traditional, assisted the children in acquiring alphabet knowledge as well as the regular program did.

The GRTR test results showed no significant difference between conditions at pretest and posttest. There was also no difference between conditions for learning gains. However, on this standardized test, the experimental conditions had higher learning gain and stronger effect sizes compared to the control condition. As an early literacy screening tool, GRTR measures not only alphabet knowledge but also other constructs relevant to early literacy skills, such as print knowledge, phonology awareness, and early writing (Phillips et al., 2009). It can therefore be safely concluded that the storytelling activities supported the development of these early literacy skills, although maybe not specifically strong in alphabet knowledge. It may be that the children benefited from the story that systematically linked instructions and follow-up activities (both the storytelling and the play-base activities). This corroborate the ideas of Lisenbee and Ford (2018) who mentioned that storytelling, as a powerful literacy tool, easily integrates activities by engaging the children in experience with the objectives and the real world. The story lines chosen for each week topic seemed to hold the children effectively engaged for their literacy activities through the day, and perhaps even throughout the week.

The ELA test results showed a stronger development in the two experimental conditions than in the control. The difference was statistically significant and the effect size showed the change to be strong. This finding replicates the outcome of tow earlier studies, one involving a shorter (3week) intervention (Maureen et al., 2018) and the other involving slightly older participants who engaged in the same intervention as the present study (Maureen et al., 2020). In other words, the finding is a stable result across studies and supportive of the effectiveness of a structured storyline approach to early literacy development.

A speculative account as to why digital storytelling showed a slightly higher gain compared to storytelling is that the use of digital elements can contribute to motivating young children throughout their day activities. There is little evidence that young children are receiving positive, or informed exposure to computer interactions at home, or in school (Paciga \& Donohue, 2017). Bringing digital storytelling into early classroom could be a good start that offers an example of a good practice for utilizing digital media for learning both for the students and teachers. Apart from the concerns about the role of digital media in young children's lives, utilizing digital media in well-planned activities can increase children's motivation and concentration thus offer rich opportunities for early literacy development (Flewitt et al., 2015).

The findings from the present study provide two main suggestions. Firstly, more effort is needed to mobilize the motivating qualities of digital media and hence enhance learning, because the present study found no difference between storytelling and digital storytelling for children's literacy development.Second, they support the choice for a design approach that is both explicit and systematic, and involves storytelling as well. Explicit means that teachers directly teach and model key letter-sound relationships and decoding skills since one should not assume that children acquire these skills simply from exposure to words or from incidental learning opportunities. Systematic means that the instruction is carefully planned and organized so that children learn prerequisite skills before they engage with more complex skills. Storytelling means 
ensuring that there is a clear connection between instructions and follow-up activities and that both moments present a meaningful experience for the children.

The content of the designed units introduced the children to both constrained and unconstrained components of early literacy skills, but the assessment involved only the former. One limitation of the present study is therefore that there was no measurement of unconstrained early literacy skills. Another limitation is that the set of activities concentrated on cognitive development. Thus, the study bypassed the value of storytelling for its own sake. Keeping the children's interest and motivation while engagement in literacy activities are important factors in the development of early literacy skills (Baroody \& Diamond, 2016). Future research should therefore examine the effectiveness of the intervention for its effectiveness on student motivation and interest. The present study showed that the structured storytelling and digital storytelling activities effectively enhanced basic early literacy skills development. The approach thus provides a sound basis for further improvements. 


\section{REFERENCES}

Abasi, M., \& Soori, A. (2014). Is storytelling effective in improving the English vocabulary learning among Iranian children in kindergartens? International Journal of Education \& Literacy Studies, 2(3), 7-11. https://doi.org/10.7575/aiac.ijels.v.2n.3p.7

Banerjee, R., Alsalman, A., \& Alqafari, S. (2016). Supporting sociodramatic play in preschools to promote language and literacy skills of English language learners. Early Childhood Education Journal, 44(4), 299-305. https://doi.org/10.1007/s10643-015-0715-4

Baroody, A. E., \& Diamond, K. E. (2016). Associations among preschool children's classroom literacy environment, interest and engagement in literacy activities, and early reading skills. Journal of Early Childhood Research, 14(2), 146-162. https://doi.org/10.1177/1476718×14529280

Bedard, C., Bremer, E., Campbell, W., \& Cairney, J. (2018). Evaluation of a direct-instruction intervention to improve movement and preliteracy skills among young children: A withinsubject repeated-measures design. Frontiers in Pediatrics, 5(298). https://doi.org/10.3389/fped.2017.00298

Bennett, K. K., Weigel, D. J., \& Martin, S. S. (2002). Children's acquisition of early literacy skills: Examining family contributions. Early Childhood Research Quarterly, 17(3), 295-317. https://doi.org/10.1016/S0885-2006(02)00166-7

Bodrova, E. (2008). Make-believe play versus academic skills: A Vygotskian approach to today's dilemma of early childhood education. European Early Childhood Education Research Journal, 16(3), 357-369. https://doi.org/10.1080/13502930802291777

Bowles, R. P., Pentimonti, J. M., Gerde, H. K., \& Montroy, J. J. (2014). Item response analysis of uppercase and lowercase letter name knowledge. Journal of Psychoeducational Assessment, 32(2), 146-156. https://doi.org/10.1177/0734282913490266

Brown, J., \& Rolfe, S. A. (2005). Use of child development assessment in early childhood education: Early childhood practitioner and student attitudes toward formal and informal testing. Early Child Development and Care, 175(3), 193-202. https://doi.org/10.1080/0300443042000266240

Cekaite, A., \& Björk-Willén, P. (2018). Enchantment in storytelling: Co-operation and participation in children's aesthetic experience. Linguistics and Education, 48, 52-60. https://doi.org/10.1016/j.linged.2018.08.005

Cole, R., Haimson, J., Perez-Johnson, I., \& May, H. (2011). Variability in pretest-posttest correlation coefficients by student achievement level. https://ies.ed.gov/ncee/pubs/20114033/pdf/20114033.pdf

Cooper, P. M. (2005). Literacy learning and pedagogical purpose in Vivian Paley's 'storytelling curriculum'. Journal of Early Childhood Literacy, 5(3), 229-251. https://doi.org/10.1177/1468798405058686

Fekonja-Peklaj, U., Marjanovič-Umek, L., \& Kranjc, S. (2010). Children's storytelling: The effect of preschool and family environment. European Early Childhood Education Research Journal, 18(1), 55-73. https://doi.org/10.1080/13502930903520058 
Fielding-Barnsley, R. (1997). Explicit instruction in decoding benefits children high in phonemic awareness and alphabet knowledge. Scientific Studies of Reading, 1(1), 85-98. https://doi.org/10.1207/s1532799xssr0101_5

Flewitt, R., Cremin, T., \& Mardell, B. (2016). Paley’s approach to storytelling and story acting: Research and practice. In T. Cremin, R. Flewitt, B. Mardell, \& J. Swann (Eds.), Storytelling in early childhood: Enriching language, literacy and classroom culture. Routledge.

Flewitt, R., Messer, D., \& Kucirkova, N. (2015). New directions for early literacy in a digital age: The iPad. Journal of Early Childhood Literacy, 15(3), 289-310. https://doi.org/10.1177/1468798414533560

Flynn, E. E. (2016). Language-rich early childhood classroom: Simple but powerful beginnings. The Reading Teacher, 70(2), 159-166. https://doi.org/10.1002/trtr.1487

Good, R. H., \& Kaminski, R. A. (2002). Letter naming fluency. In R. H. Good, \& R. A. Kaminski (Eds.), Dynamic indicators of basic early literacy skills (6th edition ed.). Institute for the Development of Educational Achievement.

Hirsh-Pasek, K., Golinkoff, R., Berk, L., \& Singer, D. (2009). A mandate for playful learning in preschool: Presenting the evidence. Oxford University Press.

Jones, C. D., Clark, S. K., \& Reutzel, D. R. (2013). Enhancing alphabet knowledge instruction: Research implications and practical strategies for early childhood educators. Early Childhood Education Journal, 41(2), 81-89. https://doi.org/10.1007/s10643-012-0534-9

Kamii, C., \& Manning, M. (2005). Dynamic Indicators of Basic Early Literacy Skills (DIBELS): A tool for evaluating student learning? Journal of Research in Childhood Education, 20(2), 75-90. https://doi.org/10.1080/02568540509594553

Kennedy, E., Dunphy, E., Dwyer, B., Hayes, G., McPhillips, T., Marsh, J., O’Connor, M., \& Shiel, G. (2012). Literacy in early childhood and primary education. https://www.ncca.ie/media/2137/literacy_in_early_childhood_and_primary_education_38_years.pdf

Langford, R. (2010). Critiquing child-centred pedagogy to bring children and early childhood educators into the centre of a democratic pedagogy. Contemporary Issues in Early Childhood, 11(1), 113-127. https://doi.org/10.2304/ciec.2010.11.1.113

Lisenbee, P. S., \& Ford, C. M. (2018). Engaging students in traditional and digital storytelling to make connections between pedagogy and children's experiences. Early Childhood Education Journal, 46(1), 129-139. https://doi.org/10.1007/s10643-017-0846-x

Maureen, I. Y., van der Meij, H. \& de Jong, T. (2018) Supporting literacy and digital literacy development in early childhood education using storytelling activities. International Journal of Early Childhood, 371-389. https://doi.org/10.1007/s13158-018-0230-z

Maureen, I. Y., van der Meij, H., \& de Jong, T. (2020). Enhancing storytelling activities to support early (digital) literacy development in early childhood education. International Journal of Early Childhood, 52(1), 55-76. https://doi.org/10.1007/s13158-020-00263-7

Missall, K. N., Carta, J. J., McConnell, S. R., Walker, D., \& Greenwood, C. R. (2008). Using individual growth and development indicators to measure early language and literacy. Infants \& Young Children, Vol. 21( No. 3), 241-253. https://doi.org/10.1097/01.iyc.0000324553.85187.dc 
Moyle, M. J., Heilmann, J., \& Berman, S. S. (2013). Assessment of early developing phonological awareness skills: A comparison of the preschool individual growth and development indicators and the phonological awareness and literacy screening-PreK. Early Education and Development, 24(5), 668-686. https://doi.org/10.1080/10409289.2012.725620

National Research Council. (2000). Assessment in early childhood education in Eager to learn: Educating our preschoolers (pp. 233-260). Washington, DC: The National Academies Press. https://doi.org/10.17226/9745

Nicolopoulou, A., Cortina, K. S., Ilgaz, H., Cates, C. B., \& de Sa, A. B. (2015). Using a narrative- and play-based activity to promote low-income preschoolers' oral language, emergent literacy, and social competence. Early Childhood Research Quarterly, 31, 147-162. https://doi.org/10.1016/j.ecresq.2015.01.006

Paciga, K. A., \& Donohue, C. (2017). Technology and interactive media for young children. Fred Rogers Center for Early Learning and Children's Media at Saint Vincent College: https://www.fredrogerscenter.org/wp-content/uploads/2017/07/Technology-andInteractive-Media-for-Young-Children.pdf

Paris, S. G. (2005). Reinterpreting the development of reading skills. Reading research quarterly, 4O(2), 184-202. https://doi.org/10.1598/RRQ.40.2.3

Phillips, B. M., Lonigan, C. J., \& Wyatt, M. A. (2009). Predictive validity of the get ready to read! Screener: Concurrent and long-term relations with reading-related skills. Journal of learning disabilities, 42(2), 133-147. https://doi.org/10.1177/0022219408326209

Piasta, S. B., Purpura, D. J., \& Wagner, R. K. (2010). Fostering alphabet knowledge development: A comparison of two instructional approaches. Reading and Writing, 23(6), 607-626. https://doi.org/10.1007/s11145-009-9174-x

Puranik, C. S., Petscher, Y., \& Lonigan, C. J. (2013). Dimensionality and reliability of letter writing in 3to 5-year-old preschool children. Learning and Individual Differences, 28, 133-141. https://doi.org/10.1016/j.lindif.2012.06.011

Robin, B. R. (2008). Digital storytelling: A powerful technology tool for the 21st century classroom. Theory Into Practice, 47(3), 220-228. https://doi.org/10.1080/00405840802153916

Robin, B. R. (2016). The power of digital storytelling to support teaching and learning. Digital Education Review, 30, 17-29. https://doi.org/10.1344/der.2016.30.17-29

Rohde, L. (2015). The comprehensive emergent literacy model: Early literacy in context. SAGE Open, 5(1), 2158244015577664. https://doi.org/10.1177/2158244015577664

Roig, A., Pires de Sá, F., \& Cornelio, G. S. (2018). Future story chasers: An experience with co-creation of fiction in the classroom through a collaborative storytelling game. Catalan Journal of Communication \& Cultural Studies, 10(2). https://doi.org/10.1386/cjcs.10.2.279_1

Roslan, R. (2008). The use of stories and storytelling in primary science teaching and learning. Studies in Education, 12, 79-89.

Ryan, M.-L. (2004). Beyond myth and metaphor: Narrative in digital media. Game Studies, 1(1). http://www.gamestudies.org/0101/ryan/ 
Sadik, A. (2008). Digital storytelling: A meaningful technology-integrated approach for engaged student learning. Educational Technology Research and Development, 56(4), 487-506. https://doi.org/10.1007/s11423-008-9091-8

Smith, P. L., \& Ragan, T. J. (2005). Instructional design (3rd ed.). Wiley.

Sunday, K. E. (2018). Drawing and storytelling as political action: Difference, plurality, and coming into presence in the early childhood classroom. International Journal of Art \& Design Education, 37(1), 6-17. https://doi.org/10.1111/jade.12097

Wells, G. (1986). The meaning makers: Children learning language and using language to learn. Heinemann.

Wessel-Powell, C., Kargin, T., \& Wohlwend, K. E. (2016). Enriching and assessing young children's multimodal storytelling. The Reading Teacher, 70(2), 167-178. https://doi.org/10.1002/trtr.1491

Whitehurst, G. J. (2001). Get ready to read! Screening tool technical report. http://www.getreadytoread.org/images/content/downloads/GRTR_screening_tool/technic alreport.pdf

Yuksel-Arslan, P., Yildirim, S., \& Robin, B. R. (2016). A phenomenological study: Teachers' experiences of using digital storytelling in early childhood education. Educational Studies, 42(5), 427-445. https://doi.org/10.1080/03055698.2016.1195717

Zettler-Greeley, C. M., Bailet, L. L., Murphy, S., DeLucca, T., \& Branum-Martin, L. (2018). Efficacy of the Nemours BrightStart! early literacy program: Treatment outcomes from a randomized trial with at-risk prekindergartners. Early Education and Development, 29(6), 873-892. https://doi.org/10.1080/10409289.2018.1475202 


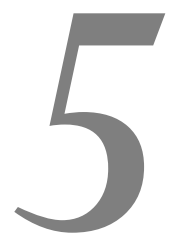

General discussion 


\section{Aim OF DiSSERTATION}

This dissertation sets out to create and test an instructional approach to enhance literacy and digital literacy of children in early childhood education in Indonesia. The approach deviated from the rapidly growing tendency to formalize early childhood by presenting a natural way of learning for these children while at the same time keeping it well organized. The resulting approach was a series of lessons in which storytelling formed the main body that was incorporated in Gagné's nine events of instruction.

\section{INTRODUCTION}

Literacy is considered a vital skill for academic achievements throughout the school years and beyond (McConnell \& Wackerle-Hollman, 2016). Therefore, it is not surprising that literacy development teaching is mostly carried out through formalized educational programs. Such an educational approach is to be expected in elementary education and later years, but it is now becoming more and more common in kindergarten as well (Bassok et al., 2016) including in Indonesia.

In a variety of contexts, early childhood teachers increasingly assign part of the daily schedule to literacy development using a formalized instructional approach (Rupley et al., 2009). In such an approach, the moment of instruction is heavily teacher-centered. That is, the teacher gathers the children around her by seating them in a classical setting in which she tells them about a literacy topic (e.g. name writing). During the major part of this instruction, the children must sit quietly and listen to the teacher. The children only speak or repeat something after being asked to do so by the teacher. After the instruction there is a follow-up activity that tends to revolve around table-top exercises in which the children must complete worksheets. During these exercises the children must wait for the teacher's instruction to do things and they are again expected to sit still for a relatively long period of time (Ellis et al., 2017). Several longitudinal studies have found that this formalized educational approach significantly contributes to the children's literacy skills development (Piasta et al., 2010).

On the one hand, a formalized approach offers children the advantages of a recurrent structure for each lesson. Such a structure is likely to benefit the children because it enables them to predict what will happen next, which can strengthen their feelings of being secure and prepared. The repetitive structure also helps the children in learning by taking small steps at a time and moving from simple to more complex tasks. Planning the activities within structure shows the children how to structure their own activities. Furthermore, having a fixed format will help teachers since some teachers may be less confident with more fluid or free play pedagogy, having a fixed format will help them (Pascal et al., 2019). In addition, a specific structure for the daily activities can provide a sense of control and practicality both for teachers and the parents and communities to assure the achievement of children's literacy development.

On the other hand, there are some costs that are accrued to adopting a formalized approach to teaching in early childhood education. Some researchers argue that kindergarten children need more opportunities for personal development as a foundation in literacy development (Johnson, 
2010). When the instruction is heavily teacher-centered the children are always following the teacher's direction which deprives them from the opportunity to develop important personal skills such as initiative taking, creativity, and imagination (Marcon, 2002). Another argument against a heavily formalized education is that such an approach leaves little room for creating an engaging and interactive environment in which literacy skills naturally are called upon and evolve (Rushton et al., 2003). Having to sit still and wait for the teacher to be called upon is not conducive to develop an atmosphere in which children naturally engage in literacy activities. A formalized instruction may therefore obstruct a long term objective of self-initiated literacy development (Bodrova, 2008).

In short, it is argued that whereas creating a structure for the children's activities is likely to benefit their literacy development, a too formalized approach can be counter-productive. This stance is in line with many researchers who argue in favour of teaching such goals in a more playful manner (e.g. Balfanz et al., 2003; Sarama \& Clements, 2009), though not only free play. Roskos et al. (2010) proposed that play should not be a stand alone activity and structured instruction in early literacy skills is advised to complement play-related strategies. Therefore, supporting literacy development in early childhood needs to be systematically structured, to give motivation for personal development, and to be in a more engaging and interactive learning environment.

\section{THE DESIGN OF THE INSTRUCTION}

In order to support children's literacy development in an appropriate way, a set of activities were systematically structured with the framework of Gagné's events of instructions and a storytelling approach. The events structure the instructions and activities. The storytelling approach connects these. It serves as a common thread that conveys the main aim of each activity and keeps the children's interest, building the engaging and interactive atmosphere within the structured activities. In this dissertation, the designed set of activities comprise two main phases: storytelling and follow-up activities.

Storytelling is considered as a powerful approach to transmit knowledge, culture, perspectives, and points of view (Sugathan \& Kalid, 2009). The use of storytelling as a teaching method in early classrooms has been widely encouraged because it is entertaining and seen as a natural way of teaching and learning with young children (Kucirkova et al., 2017). Storytelling can keep the children's attention and help them listen and learn more actively than other forms of instruction. Furthermore, it is also evident that in this 21st century children are increasingly involved in storytelling interactions across multiple media platforms. Through vlogs, blogs, Facebook and Instagram, children are becoming immersed in storytelling on a grand scale. Introducing storytelling activities in early childhood education may then benefit from bringing digital technology yielding a form of digital storytelling. Digital storytelling combines the art of telling stories with a mixture of digital media, including pictures and narration (Arslan et al., 2016). In other words, digital storytelling offers children story content in digital, technology-based formats. 
In this dissertation, the storytelling sessions were carried out in two ways, oral storytelling and digital storytelling, under the same storylines. We investigate whether storytelling delivered in either way supported literacy development in early childhood education. In both approaches, the storytelling session provided the objectives, contents, and engagement for literacy experience in the second phase - the follow up activities. This concept aligns with the view that storytelling should be followed by play-based activities (Nicolopoulou et al., 2015) or topic-related activities (Agosto, 2016) in which children can further hone their literacy skills. In addition, it aligns with a structured instructional design approach in which follow-up activities serve to further establish and refine newly acquired information. In the present study, the follow-up activities involve Smilansky's four types of play (Dodge \& Bickart, 1998) in early childhood education, namely functional play, constructive play, games with rules, and dramatic play. These types of play are also included as recommended strategies of activities within the early childhood curriculum of Indonesia - Curriculum 2013. Functional play is simply playing to observe the surrounding and enjoy the experience. This kind of play helps children learn about the world through their senses, supports social-emotional development, and strengthens motor skills. Constructive play involves creating something (building, drawing, crafting, etc.). Constructive play is goal-oriented. The onset of this kind of play shows that children are developing the ability to plan. Constructive play promotes creativity and problem solving, and gives children a sense of accomplishment. Games with rules are explored with the aim of understanding the social meaning of games and basic understanding of rules. Dramatic play or pretend play revolves around the understanding that objects, actions, or ideas can represent other objects, actions, or ideas.

Jointly, the storytelling and follow-up phase establish a suitable pedagogical framework in early childhood education that enables a high degree of engagement and interactivity proposed (Sproule et al., 2019). The realization of such a supportive environment creates an atmosphere in which children can naturally engage in literacy activities.

To add more, along with an increasing role of digital technology in children's lives, comes the call for literacy development that extends beyond the traditional areas of reading and writing. The children need to learn the basic concepts of how to handle digital technology, bringing in a broader sense of literacy. An analytical survey from UNESCO (Kalaš, 2010) highlighted the importance of support for extended forms of literacy development in early childhood education. However, current efforts to the development of literacy in early childhood education still mostly revolve around the traditional skills of reading and writing, and most of the time additional digital training revolves around computer usage and thus on supporting technical skills development. Following the dynamic trend of digital devices usage, digital literacy is often taken too narrowly as involving only the technical skills needed (Buckingham, 2010). Among the three dimensions of digital literacy namely technical, cognitive, and socio-emotional ( $\mathrm{Ng}, 2015)$, the technical skills required will always be changing along with the evolving digital devices, while the other dimensions relatively stay the same. Therefore, this thesis focuses on enhancing children's cognitive and social abilities in order to be able to strengthen the understanding of the appropriate use of digital media later in life. 


\section{THE SET-UP AND MAIN FINDINGS OF THE THREE EMPIRICAL STUDIES}

The dissertation presents three studies that assessed the effectiveness of storytelling and digital storytelling activities on children's (digital) literacy development in a natural context. The studies were performed on public kindergartens (4-6 year old children) in Surabaya, Indonesia. The researcher acted as one of the teachers as she was an experienced kindergarten teacher herself.

All studies involved three conditions. In the control condition the regular literacy lessons were given. In these lessons, the children had the regular, weekly literacy-oriented program within the same topics. The program included reading and writing practice for children, e.g. words spelling for reading practice or tracing their own name for writing practice. The control condition was to provide baseline data and to control for the event that changes that were found in the studies might be caused by maturation, which for children of this age is very plausible. In the two experimental groups the lessons revolved around storytelling. In one condition there was oral storytelling. In the other there was digital storytelling. To our knowledge, much of the research on literacy development in early childhood education is of a qualitative nature (Teale et al., 2020). A controlled experimental design was chosen to provide evidence of a causal relationship between the interventions and the literacy development that was measured.

The first study was intended to develop a prototypical design for the storytelling activities, and to create a set of pertinent measures for assessing literacy and digital literacy development. The designs and measures were changed slightly in the two studies that followed. Table 1 gives an overview of characteristic changes over time in the three studies. There were four main developments. One, an important change involved an expansion of the length of the lessons. In Study 1 , a series of three lessons of two and a half hours were given over a three week period. In Study 2 this was expanded into a series of six lessons (each of the same length) that were given over a six week period. The change served to illustrate that the lessons could be expanded into a longer curriculum while keeping intact their main design characteristics. In addition, the change meant that the intervention was less susceptible to a novelty effect. Two, the age of the target group in all studies was kept more or less constant, only an effort was made to include more children and to record more measures of each child. Three, a change was made regarding the decision of the instructor who taught the lessons. In the first two studies, the storytelling in the experimental conditions were led by the experimenter, while the instructions in the control condition were led by the regular teacher. During the follow-up activities, the teacher or experimenter served as a teaching assistant and vice versa. This decision was adopted to disrupt as little as possible the normal classroom routines in the control classroom. In Study 3, all conditions were led by the experimenter, an experienced teacher, to ameliorate the potential effect of instructor differences. Four, the measures to record literacy and digital literacy development changed slightly over time. In Studies 1 and 2, both before and after the intervention the children's literacy was assessed with self-developed instruments. In Study 3 , complementary standardized tests were used to investigate whether a similar increase in literacy and digital literacy developments that was found for the self-developed instruments could also be found on these tests. To avoid over-testing, there was no assessment of digital skills development in this study. 
Table 1

A summary of the main differences in set-up of the three studies

\begin{tabular}{|c|c|c|c|}
\hline Aspect & Study 1 & Study 2 & Study 3 \\
\hline Lessons & 3 lessons & 6 lessons & 6 lessons \\
\hline $\begin{array}{l}\text { Participants; mean } \\
\text { age }\end{array}$ & 45 children; 5.4 yrs & 62 children; 5.6 yrs & 59 children; 5.1 yrs \\
\hline Instructor & $\begin{array}{l}\text { Control - regular } \\
\text { teacher } \\
\text { Exp - experimenter }\end{array}$ & $\begin{array}{l}\text { Control - regular } \\
\text { teacher } \\
\text { Exp - experimenter }\end{array}$ & $\begin{array}{l}\text { Control \& } \\
\text { Experimental- } \\
\text { experimenter }\end{array}$ \\
\hline Tests & $\begin{array}{l}\text { Early Literacy } \\
\text { Assessment } \\
\text { Early Digital Literacy } \\
\text { Assessment }\end{array}$ & $\begin{array}{l}\text { Early Literacy } \\
\text { Assessment } \\
\text { Early Digital Literacy } \\
\text { Assessment }\end{array}$ & $\begin{array}{l}\text { Early Literacy } \\
\text { Assessment } \\
\text { Standardized: } \\
\text { DIBELS - alphabet test } \\
\text { GRTR test }\end{array}$ \\
\hline
\end{tabular}

The main findings from Study 1 can be summarized as follows. The self-developed tests for assessing literacy and digital literacy were found to be reliable. The children who had engaged in the regular activities (the control condition) raised their literacy skills only slightly. The oral storytelling condition improved significantly more than the control condition. Also, a substantial increase in literacy skills development was found for the digital storytelling condition. The increase in this condition was significantly higher in comparison to both that of the control and oral storytelling condition. All three conditions showed a significant increase in digital skills development. On these tests, the oral and digital storytelling condition showed a significantly and substantially higher increase compared with the control condition. No difference was found between the two storytelling conditions on their digital skills development.

The main findings from Study 2 essentially replicated and extended the outcomes of Study 1 . The longer duration of the intervention showed up in the relatively larger increase in literacy skills development compared with study 1 . In all three conditions there was a significant and substantial improvement. The two storytelling conditions increased their literacy skills significantly more than the control condition. There was no significant difference in literacy skills development between the two storytelling conditions. Just as in study 1 , all conditions showed considerable improvements in their digital skills. The increase was significant only for the two storytelling conditions, which did not differ in development.

The main findings from Study $\mathbf{3}$ essentially replicated the findings from study 2 for literacy skills development as measured with the self-developed tests. All three conditions improved their literacy skills over time, and the two storytelling conditions did so significantly and substantially more than the control condition. The findings on the two standardized tests also revealed that the three conditions significantly increased their literacy skills. Both on the DIBELS and GRTR significant and substantial gain scores were obtained. Although the effect sizes for the digital storytelling condition were highest, there was no significant difference between conditions on these standardized literacy skills tests. 
The general conclusions that can be drawn from these studies are the following:

- An important reason for not adopting a formalized approach to teaching literacy and digital literacy in early childhood education is that such an approach may leave children with few opportunities for self-directed learning and personal skills development; An additional reason is that such an approach may not be engaging enough and limit the kind of interactions that take place.

- The three empirical studies reported in this thesis showed that a structured storytelling approach is more beneficial to developing literacy and digital literacy than is a traditional approach; It is argued that storytelling is a natural, engaging event that, in combination with play-like follow-up activities, yields an activating and effective approach to teaching and learning.

- Across studies, the digital storytelling approach consistently (but not always significantly) provided the best results of the two storytelling conditions which make this the preferred approach.

- On standardized literacy tests, the storytelling conditions did not outperform the traditional approach which is perhaps partly a matter of greater emphasis on developing alphabet skills in the latter approach.

- Literacy and digital literacy development are best seen as complementary literacies; both literacies have their own unique fundamentals (e.g., alphabet, technical skills) but they also share cognitive and motivational characteristics.

\section{DISCUSSION OF FINDINGS}

\section{The research explores more of the literacy development in early childhood than just reading and writing skills for children}

Literacy typically refers to reading and writing skills. In early childhood education, children need to develop the early literacy skills that will support their ability to read and write. These skills include letter knowledge, print awareness, phonological awareness, and emergent writing skills. These are considered the precursors to literacy. In the 21st century, as the dependency on, and influence of, digital technology grows, the concept of early literacy should include facets of the precursors of digital literacy also. To become literate, individuals would need to develop skills that extend beyond the traditional areas of reading and writing, and co-develop digital literacy.

As with traditional literacy where the precursors to early literacy are the skills that contribute to reading and writing abilities, early digital literacy can be characterized as involving the precursors that contribute to the skills that enable children to engage as a consumer and producer of digital technology. Very little is known about the nature of these precursors to digital literacy. A distinction can be made between the skills, knowledge, and attitudes towards digital literacy (Neumann et al., 2017). In the present study the focus was on the cognitive and social-emotional dimensions of early digital literacy $(\mathrm{Ng}, 2015)$. Both aspects could be connected to storytelling characteristics. For cognitive aspects we looked at identifying a picture in a storybook, and also planning and predicting an event. These skills are related to storytelling since it is indeed delivering multimodal contents 
such as verbal (forms of language), vocal (manipulation of voice), visual (gestures and facial expressions) (Lwin, 2016). Through listening to stories children could develop the ability of learning strategies like planning and predicting (Porras, 2010). For social-emotional aspects we looked at the recognition of one's own identity and recognition and usage of conversational rules. Listening to storytelling allows the children to be engaged in different stories while they are reflecting on themselves and learning social skills (León-Garzón \& Castañeda-Peña, 2018).

\section{The use of technology in early classrooms}

Through the process of conducting this research, there is one major concern that has been addressed in this thesis - digital technology in early classrooms. Several organizations have raised concerns about technology exposure. For example, the American Academy of Pediatrics (AAP) expressed concern about the increased usage of digital devices and espoused the position that young children need hands-on exploration and social interaction to develop cognitive, language, motor, and social-emotional skills (Council on Communications and Media, 2016). An overexposure to digital technology puts these developments at risk. The AAP further claimed that young children may have difficulty transferring knowledge attained from screen media to their three-dimensional experiences. Also, the Canadian Paediatric Society (CPS) cited five studies connecting young children's TV watching to language delays (Chonchaiya \& Pruksananonda, 2008). Accordingly, the CPS argued that there should be no screen time for children under twoyears and no more than one hour per day for children between the ages of two- and five-years.

Despite the concerns, many studies indicate that young children observe their family members using digital tools regularly at home and, in many cases, have access to these (Livingstone \& Helsper, 2007; Otterborn et al., 2018). These experiences do not automatically bring it about that the children become digital natives. They still need to learn how to use the digital technology in a proper way. Bringing digital storytelling into the early classroom seems a good option for introducing children to digital technology usage since it involves a relatively short exposure time (much less than the maximum duration set by the CPS) and, especially in this research, it is followed by theme-integrated hands-on activities that support a balanced diet of digital - non digital activities through the day.

\section{The concentration on the cognitive and social-emotional skills}

In this thesis we also integrated digital literacy skills with 'regular' literacy skills and we did not focus their development on the technical component but concentrated on the cognitive and socialemotional skills. The fast growing of digital technology has made the new literacy rapidly changing and situational (Leu et al., 2017), especially when it comes to digital tools such as tv, computer, tablet, or smartphones. Therefore, in assisting the development of digital literacy in early classrooms there should be an emphasis on developing generic, simple and basic skills. For example, instead of teaching how to turn the computer on and off as it used to be in the curriculum for computer extra lessons - the children could be taught to recognize universal symbols used in digital tools, since recognizing pictures will help in comprehending multimodal messages. Another example is preparing the children to do coding, where children could start with playing hopscotch or arrange different wood blocks into patterns - since the basic concept of coding is understanding patterns. 


\section{Impact for teachers}

The teacher plays a crucial role in motivating the children and helping them to self-reflect, among others (Eisazadeh \& Rajendram, 2020). In the experiment schools, most teachers handle the class of 15-20 children all by themselves, though sometimes they teach in couples. In a free play classroom, most teachers are less confident since they seem to lose control of the children and the learning, and with a relatively large class (above 20 ) it will be even more difficult. A teacher's role is just as complex, as they need to be able to respond in different ways appropriate to each play situation, whether actively or by taking a step back. The designed activities are developmentallyappropriate structured so it is relatively easy to keep control of the learning pace and the story itself helps with motivating the children all through the day or even week. Moreover, it allows children to actively engage in large group interaction during storytelling activities and then engage in small group activities during the follow up sessions. With these storytelling activities, there are structures that give the teacher a sense of control.

\section{LIMITATIONS AND DIRECTIONS FOR FUTURE RESEARCH}

There are some issues that were not addressed in the research. One, effects of the separate elements of either storytelling or digital storytelling should be further investigated. In this thesis we have chosen an integral approach and tested all elements of storytelling as one. Elements that can be distinguished within storytelling are setting, theme, characters, plot, and conflict (Lisenbee \& Ford, 2017). For digital storytelling elements that are mentioned in the literature are specific point of view, a dramatic question, emotional content, the gift of voice, power of soundtrack, economy, and pacing (see Robin, 2006). Each of these elements, and their interactions, can have a unique effect on students' development of literacy or digital literacy development. Therefore, it is interesting to know how each element contributes to these developments so that more varied, or effective storytelling activities can be designed. This thesis has shown that a storytelling approach has great potential for literacy and digital literacy development in early childhood education. With more insights into the nature and contribution of each element in these approaches, a window of opportunities open up for creating more varied activities, for expanding the series of activities to a full-year curriculum, as well as for creating the most effective designs. Also, these deeper insights may stimulate the development of dedicated tests for assessing the contribution of these storytelling events to children's understanding and creation of stories (and also literacy).

Two, it has been assumed that the storytelling and digital storytelling lessons appealed to the children's natural way of learning. It was assumed that these lessons triggered the children's interest and kept them motivated to persist in engaging with the literacy activities. This assumption was never questioned or investigated in the present study. There were incidental observations, of course, that led us to believe that the lessons were appealing to the children. For instance, it struck (but did not surprise) us that the children in all three studies seemed really fond of the stories. One tell-tale of their piqued interest was that the children asked their regular teacher to retell the stories on another day in the week than literacy day. Another signal of how 
the children took to the stories was when a child who had been the main character in one of the stories entered the classroom. The children immediately started to ask this boy a lot of questions related to the themes of the stories like hobbies and favorite toys. Finally, it was apparent that third, the children really wanted to tell their own storylines. They were clearly motivated to go beyond being a consumer of stories to being also a producer of stories. As proof in point the children were eager to record their stories digitally. All in all, it seems worthwhile to systematically gather information about how the children emotionally responded to the storytelling activities.

Three, the measurement of early digital literacy development in this research was limited to cognitive and social-emotional aspects. And in the way these aspects were measured, one could argue that the digital literacy assessment in the present study was rather generic in nature and not primarily focused on digitalization. That is, people usually classify all kinds of operational skills of specific tools under the rubric of digital literacy (Ozturk \& Ohi, 2018; Oakley et al., 2018). Thus, it is far more common to find measures that assess whether children can turn a computer or laptop on or off, whether they know how to handle a mouse, or whether they can play an educational game on a tablet (learning to swipe and click/double click, etc.).

Finally, another weakness of the research is that there was no data on curriculum implementation during the studies. Although generally lessons were executed according to plan, no evidence of truthful execution was gathered. Through observations it would have been possible to record whether the storytelling activities were performed as described in the lesson plans, and whether the follow-up activities were executed as planned.

\section{GENERAL CONCLUSION}

Storytelling may enter the world of preschool children very rapidly in the near future, especially when commercial parties offer dedicated applications (e.g. iPad apps for young children) with touch technology (Decat et al., 2019) or collaborative technologies (Del-Moral-Pérez, et al., 2019). Also a recent meta-analysis shows that most of the empirical studies on digital storytelling report positive results, although that may partly be caused by a novelty effect (Wu \& Chen, 2019). The current thesis gives some guidelines on how to incorporate storytelling in the early childhood curriculum. An important consideration is that storytelling should ensure that there is a clear connection between instructions and daily activities, and that both moments present a meaningful experience for the children. Having both structured and less structured activities makes it possible to have a balanced pedagogy - give the children the experience and benefit from both approaches. Altogether, the research indicated that the integration of a storytelling approach with the didactic approach of Gagné's nine events of instruction is a promising pedagogy for enhancing literacy and digital literacy development in early childhood education. The studies have provided empirical evidence that both in oral and digital forms, storytelling activities can effectively enhance early literacy, as well as early digital literacy. It can further be concluded that the oral storytelling activities can support early digital literacy development and that digital storytelling activities can support early literacy development. 


\section{REFERENCE}

Agosto, D. E. (2016). Why storytelling matters: Unveiling the literacy benefits of storytelling. Children and Libraries, 2(14), 21-26. https://doi.org/https://doi.org/10.5860/cal.14n2.21

Arslan, P., Yildirim, S., \& Robin, B. (2016). A phenomenological study: Teachers' experiences of using digital storytelling in early childhood education. Educational Studies, 1-19. https://doi.org/10.1080/03055698.2016.1195717

Balfanz, R., Ginsburg, H., \& Greenes, C. (2003). The "Big Math for Little Kids" early childhood mathematics program. Teaching Children Mathematics, 9(5). 264-268.

Bassok, D., Latham, S., \& Rorem, A. (2016). Is kindergarten the new first grade? AERA Open, 2. https://doi.org/10.1177/2332858415616358

Bodrova, E. (2008). Make-believe play versus academic skills: A Vygotskian approach to today's dilemma of early childhood education. European Early Childhood Education Research Journal, 16, 357-369. https://doi.org/10.1080/13502930802291777

Buckingham, D. (2010). Defining digital literacy. Nordic Journal of Digital Literacy, 4, 59-71. https://doi.org/10.1007/978-3-531-92133-4_4

Chonchaiya, W., \& Pruksananonda, C. (2008). Television viewing associates with delayed language development. Acta Paediatrica, 97(7), 977-982. https://doi.org/10.1111/j.16512227.2008.00831.x

Council on Communications and Media. (2016). Media and young minds. Pediatrics, 138(5). https://doi.org/10.1542/peds.2016-2591

Decat, E., Damjanovic, V., Branson, S., Blank, J., \& Berson, I. (2019). Using touch technology to foster storytelling in the preschool classroom. Journal of Inquiry and Action in Education, 10(2). https://digitalcommons.buffalostate.edu/jiae/vol10/iss2/1

Dodge, D. T., \& Bickart, T. S. (1998). The four types of play. https://www.barron.k12.wi.us/faculty/levyw/fourtypesofplay.cfm

Eisazadeh, N., \& Rajendram, S. (2020). Supporting young learners through a multimodal digital storytelling activity. Journal of Early Childhood Education Research, 9, 76-98. https://jecer.org/wp-content/uploads/2020/02/Eisazadeh-Rajendram-issue9-1.pdf

Ellis, Y., Cliff, D. P., \& Okely, A. D. (2017). Childcare educators' perceptions of and solutions to reducing sitting time in young children: A qualitative study. Faculty of Social Sciences Papers. https://ro.uow.edu.au/sspapers/3287

Kalaš, I. (2010). Recognizing the potential of ICT in early childhood education: Analytical survey. UNESCO. https://unesdoc.unesco.org/ark:/48223/pf0000190433

Kucirkova, N., Cremin, T., Flewitt, R., Faulkner, D., \& Swann, J. (2017). Storytelling and story-acting: Co-construction in action. Journal of Early Childhood Research, 16. https://doi.org/10.1177/1476718X17750205

León-Garzón, R., \& Castañeda-Peña, H. (2018). Exploring social skills and character education of students through storytelling in L2. GIST - Education and Learning Research Journal, 17, 128-157. https://doi.org/10.26817/16925777.440 
Leu, D., Kinzer, C., Coiro, J., Castek, J., \& Henry, L. (2017). New literacies: A dual-level theory of the changing nature of literacy, instruction, and assessment. Journal of Education, 197, 1-18. https://doi.org/10.1177/002205741719700202

Lisenbee, P., \& Ford, C. (2017). Engaging students in traditional and digital storytelling to make connections between pedagogy and children's experiences. Early Childhood Education Journal, 46. https://doi.org/10.1007/s10643-017-0846-x

Livingstone, S., \& Helsper, E. (2007). Gradations in digital inclusion: Children, young people and the digital divide. New Media \& Society, 9(4), 671-696. https://doi.org/10.1177/1461444807080335

Lwin, S. M. (2016). It's story time!: Exploring the potential of multimodality in oral storytelling to support children's vocabulary learning. Literacy, 50(2), 72-82. https://doi.org/10.1111/lit.12075

Marcon, R. (2002). Moving up the grades: Relationship between preschool model and later school success. Early Childhood Research \& Practice, 4. https://ecrp.illinois.edu/v4n1/marcon.html

McConnell, S., \& Wackerle-Hollman, A. (2016). Can we measure the transition to reading? General outcome measures and early literacy development from preschool to early elementary grades. AERA Open, 2. https://doi.org/10.1177/2332858416653756

Neumann, M. M., Finger, G., \& Neumann, D. L. (2017). A conceptual framework for emergent digital literacy. Early Childhood Education Journal, 45(4), 471-479. https://doi.org/10.1007/s10643016-0792-z

Ng, W. (2015). Digital literacy: The overarching element for successful technology integration. In W. $\mathrm{Ng}$, New digital technology in education. Springer International Publishing. https://doi.org/10.1007/978-3-319-05822-1_6

Nicolopoulou, A., Cortina, K. S., Ilgaz, H., Cates, C. B., \& de Sá, A. B. (2015). Using a narrative- and play-based activity to promote low-income preschoolers' oral language, emergent literacy, and social competence. Early Childhood Research Quarterly, 31, 147-162. https://doi.org/10.1016/j.ecresq.2015.01.006

Oakley, G., Wildy, H., \& Berman, Y. E. (2018). Multimodal digital text creation using tablets and openended creative apps to improve the literacy learning of children in early childhood classrooms. Journal of Early Childhood Literacy. https://doi.org/10.1177/1468798418779171

Otterborn, A., Schönborn, K., \& Hultén, M. (2018). Surveying preschool teachers' use of digital tablets: General and technology education related findings. International Journal of Technology and Design Education, 29, 717-737.

Ozturk, G., \& Ohi, S. (2018). Understanding young children's attitudes towards reading in relation to their digital literacy activities at home. Journal of Early Childhood Research, 16(4), 393-406. https://doi.org/10.1177/1476718×18792684

Pascal, C., Bertram, T., \& Peckham, K. (2019). Integrated early years systems: A review of international evidence. https://www.wcpp.org.uk/wpcontent/uploads/2019/01/Integrated-Early-Years-Systems.pdf 
Pérez, M., \& Guzmán, A. (2014). CityVille: Collaborative game play, communication and skill development in social networks. Journal of New Approaches in Educational Research, 3, 11 19. https://doi.org/10.7821/naer.3.1.11-19

Piasta, S., Purpura, D., \& Wagner, R. (2010). Fostering alphabet knowledge development: A comparison of two instructional approaches. Reading and Writing, 23, 607-626. https://doi.org/10.1007/s11145-009-9174-x

Porras, N. (2010). Teaching English through stories: A meaningful and fun way for children to learn the language. Profile Issues in Teachers ` Professional Development, 12, 95-106.

Robin, B. (2006). The educational uses of digital storytelling. Society for Information Technology \& Teacher Education International Conference 2006, Orlando, Florida, USA. https://www.learntechlib.org/p/22129

Roskos, K., Christie, J., Widman, S., \& Holding, A. (2010). Three decades in: Priming for meta-analysis in play-literacy research. Journal of Early Childhood Literacy, 10, 55-96. https://doi.org/10.1177/1468798409357580

Rupley, W., Blair, T., \& Nichols, W. (2009). Effective reading instruction for struggling readers: The role of direct/explicit teaching. Reading \& Writing Quarterly, 25, 125-138. https://doi.org/10.1080/10573560802683523

Rushton, S. P., Eitelgeorge, J., \& Zickafoose, R. (2003). Connecting Brian Cambourne's conditions of learning theory to brain/mind principles: Implications for early childhood educators. Early Childhood Education Journal, 31(1), 11-21. https://doi.org/10.1023/A:1025128600850

Sarama, J., \& Clements, D. (2009). Building blocks and cognitive building blocks: Playing to know the world mathematically. American Journal of Play, 1, 313-337. https://eric.ed.gov/?id=EJ1069014

Sproule, L., Walsh, G., \& McGuinness, C. (2019). More than 'just play': Picking out three dimensions of a balanced early years pedagogy. International Journal of Early Years Education, 27(4), 409-422. https://doi.org/10.1080/09669760.2019.1628011

Sugathan, S. K., \& Kalid, K. S. (2009). An exploratory study of storytelling approach as an instructional tool from educators' perspective. 2009 International Conference on Computer Technology and Development. https:// 10.1109/ICCTD.2009.122

Teale, W. H., Whittingham, C. E., \& Hoffman, E. B. (2020). Early literacy research, 2006-2015: A decade of measured progress. Journal of Early Childhood Literacy, 20(2), 169-222. https://doi.org/10.1177/1468798418754939

Wu, J., \& Chen, D.-T. V. (2020). A systematic review of educational digital storytelling. Computers \& Education, 147. https://doi.org/10.1016/j.compedu.2019.103786 


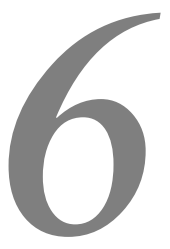

English summary 


\section{INTRODUCTION}

Literacy skills in early childhood contribute to overall academic development across the school years. This finding has stimulated research on the best way of supporting young children's literacy development. Creating a structure for children's activities is likely to be beneficial, but a too heavily formalized approach could be disadvantageous. What is needed is an approach that strikes a good balance between informal and formal activities. Activities for literacy development need to be structured but they also should contain playful moments that fit the developmental level of the children. It is crucial that an approach that stimulates early literacy development takes place in a fun and familiar learning environment that allows for engagement and interactivity, like during storytelling.

Storytelling in early childhood education has been widely encouraged because it is entertaining and seen as a natural way of teaching and learning with young children. Most likely, the children are already accustomed to storytelling in early classrooms through sessions that are mainly employed for gaining the children's attention at the beginning of a classroom activity or in between the main activities. Storytelling is also considered as a narrative play that uses verbal and non-verbal actions that contribute to children's literacy skills development, especially when it is followed by enhancement activities like discussion or retelling.

This thesis sets out to explore the design and effectiveness of an innovative approach for the development of literacy and furthermore digital literacy in early childhood education. The design integrated storytelling as a natural activity within a structured method, the nine events of instruction from Gagné. There are two main phases in the design namely storytelling led by the teacher and follow-up activities. The storytelling session provided the objectives, content, and engagement for the literacy experience in the second phase. These follow-up activities are playbased and they relate to the storylines serving to further establish and refine newly acquired information. The realization of such a supportive environment creates an atmosphere in which children can naturally engage in literacy learning activities.

\section{ABOUT THE STUDiES}

Three studies were conducted in Surabaya, Indonesia. The studies involved preschool classrooms that accommodated 4-6 year-old kindergarten children. The research design was quasiexperimental with three conditions. Classrooms were randomly assigned to conditions: Control, oral storytelling, and digital storytelling. In the control condition, the children received their regular classroom literacy enhancement activities like spelling, tracing, or name writing. In one experimental condition, the children received oral storytelling activities, in which a story was read aloud and presented with some visual clues. In the other experimental condition, the children received digital storytelling activities and the children watched and listened to pre-recorded stories that were projected in front of the class. The corresponding follow-up activities were likewise carried out in two ways, oral storytelling and digital storytelling, under the same storylines. 
The instructional materials are organized into six units. Each unit was conducted during one day once a week. These units revolved around common themes that are addressed in the beginning of the academic year during the time this Study took place. Each unit had two or three objectives that aimed to contribute to early literacy or early digital literacy skills development. These objectives become the main lines in the storytelling and also in the follow-up activities. The theme for the storytelling sessions was "Me". This is a common theme for classroom activities at the beginning of the school year. In Study 1, there were three sessions (units). In both Study 2 and 3, there were six sessions (units). In Study 1 and 2, only the experimental conditions were led by the experimenter. In Study 3, all conditions were led by the experimenter.

Along with the new activities designs, there are also self-developed set of tests focused on assessing early literacy and early digital literacy development. The effectiveness of storytelling activities on children's (digital) literacy development were assessed in a somewhat natural context. Two sets of assessments were developed. The early literacy assessment set (in Study 1, 2 , and 3) focused on skills for reading and writing such as alphabet knowledge, phonological awareness, and print awareness. The early digital literacy assessment set (in Study 1 and 2) focused on two dimensions of early digital literacy namely cognitive (critical thinking and multimodality) and social emotional (communication and social ability). Other than the selfdeveloped tests, there were also two standardized tests used in Study 3.

\section{STUDY 1}

We investigated whether the initial design of storytelling activities, traditional and digital, would increase children's literacy development more than in the control condition. This Study also explored the effect on digital literacy development. The main findings from Study 1 can be summarized as follows. The self-developed tests for assessing literacy and digital literacy were found to be reliable. The children who had engaged in the regular activities (the control condition) raised their literacy skills only slightly. The oral and digital storytelling conditions improved these skills significantly more than the control condition. The increase in the digital condition was significantly higher in comparison to both that of the control and oral storytelling condition. All three conditions showed a significant increase in digital skills development. On these tests, the experimental conditions showed a significantly and substantially higher increase compared with the control condition. No difference was found between the two experimental conditions on their digital skills development.

\section{STUDY 2}

This Study again focuses on the effect of storytelling and digital storytelling activities on the literacy and digital literacy development of young children. The development of these skills was investigated in two experimental (story telling) conditions and a control condition. The main findings from Study 2 essentially replicated and extended the outcomes of Study 1 to a context of six weeks of literacy activities. The longer duration of the intervention showed up in the relatively larger increase in literacy skills development compared with Study 1. In all three conditions there 
was a significant and substantial improvement in this skill. The two storytelling conditions increased their literacy skills significantly more than the control condition. There was no significant difference in literacy skills development between the two storytelling conditions. Just as in Study 1 , all conditions showed considerable improvements in their digital skills. The increase was significant only for the two storytelling conditions, which did not differ in development.

\section{STUDY 3}

This Study also reports on the effectiveness of a series of activities over a 6-week period that aimed to enhance early literacy development. The development of digital literacy was not recorded in this Study. The set-up from Study 2 was repeated and measurements were extended with standardized tests for early literacy. Children were assessed before and after the intervention for their early literacy skills development using two standardized tests (i.e., DIBELS and GRTR) and a self-developed test. The main findings from Study 3 essentially replicated the findings from Study 2 for literacy skills development as measured with the self-developed tests. All three conditions improved their literacy skills over time, and the two storytelling conditions did so significantly and substantially more than the control condition. The findings on the two standardized tests also revealed that the three conditions significantly and substantially increased their literacy skills. Although the effect sizes for the digital storytelling condition were highest, there was no significant difference between conditions on these standardized literacy skills tests.

\section{CONCLUSION}

The three empirical studies reported in this thesis showed that a structured storytelling approach is more beneficial to developing literacy and digital literacy than is a conventional approach. It is argued that storytelling is a natural, engaging event that, in combination with play-like follow-up activities, yields an activating and effective approach to teaching and learning. This thesis thus provides tentative evidence that a structured storytelling approach that is structurally integrated into the children's daily activities can enhance their literacy and their digital literacy skills concurrently. 


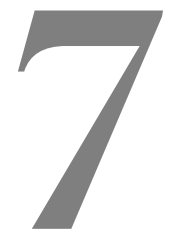

Nederlandse samenvatting 


\section{INLEIDING}

Geletterdheid van jonge kinderen draagt bij aan de ontwikkeling van hun algemene academische ontwikkeling gedurende de schooljaren. Deze bevinding heeft geleid tot onderzoek naar de beste wijze om deze geletterdheid van jonge kinderen te stimuleren. Een structurele aanpak kan deze ontwikkeling ondersteunen, maar een te formele benadering kan negatieve gevolgen hebben. Een benadering is daarom gewenst waarin een goede balans bestaat tussen formele en informele activiteiten. De activiteiten van de kinderen moeten gestructureerd zijn, maar tevens speelse momenten bevatten die aansluiten bij hun ontwikkelingsniveau. Het is van essentieel belang dat een benadering om de geletterdheid van jonge kinderen te bevorderen plaatsvindt in een plezierige, vertrouwenwekkende leeromgeving die ruimte biedt voor betrokkenheid en interactiviteit, zoals tijdens het verhalen vertellen.

Verhalen vertellen in de eerste klassen van het basisonderwijs wordt alom bevorderd omdat het een plezierige bezigheid is en omdat het een natuurlijke manier is waarop jonge kinderen worden onderwezen en dingen leren. De kinderen zijn vaak al bekend met deze activiteit doordat verhalen vertellen gewoonlijk wordt gebruikt om de aandacht te trekken bij aanvang van een klasse-activiteit, of als tussendoortje functioneert bij een wisseling van hoofdactiviteiten. Verhalen vertellen wordt soms ook gebruikt als spelvorm met verbale en niet-verbale activiteiten. Vooral wanneer hierop aanvullende stimulerende activiteiten volgen, zoals een discussie of navertellen, draagt dit bij aan de ontwikkeling van geletterdheid.

In deze dissertatie wordt het ontwerp en de effectiviteit onderzocht van een innovatieve benadering om geletterdheid en digitale geletterdheid in de eerste klassen van het basisonderwijs te bevorderen. De aanpak integreert verhalen vertellen als natuurlijke activiteit in een gestructureerd proces, te weten de negen instructie activiteiten van Gagné. Er zijn twee hoofdmomenten in de aanpak: verhalen vertellen onder leiding van de leerkracht en vervolgactiviteiten. Het moment van verhalen vertellen moet de kinderen motiveren en verduidelijkt de doelen en inhoud van de geletterdheidsactiviteiten die volgen. Deze vervolgactiviteiten hebben een spelvorm. Ze zijn verbonden met het thema van het verhaal die ze versterken en uitwerken. Op deze wijze wordt een ondersteunende en aangename leeromgeving gevormd waarin de kinderen op natuurlijke wijze actief zijn in, en leren van, geletterdheidsactiviteiten.

\section{OVER DE STUDIES}

Drie empirische studies zijn uitgevoerd in Surabaya in Indonesië. De studies betroffen steeds klassen met kinderen van 4-6 jaar uit het basisonderwijs. Het ontwerp was quasi- experimenteel met drie condities: controle, mondeling verhalen vertellen en digitaal verhalen vertellen. Elke klas werd random toegewezen aan een van deze condities. In de controle conditie namen de kinderen deel aan de reguliere geletterdheidsactiviteiten van de school zoals spellen, natrekken of het schrijven van je naam. In een experimentele conditie stonden mondelinge verhalen centraal. In deze conditie werd een verhaal hardop gelezen en werden bijbehorende plaatjes getoond. In de andere experimentele conditie stonden digitale verhalen centraal. In deze conditie keken en 
luisterden de kinderen naar opgenomen verhalen die op een scherm vooraan in de klas werden afgespeeld. Beide experimentele condities bevatten vervolgactiviteiten die afgestemd waren op de voorafgaande instructies. Het accent lag hierbij op mondelinge of digitale verwerking.

Het instructiemateriaal was georganiseerd in zes units. Elke unit werd uitgevoerd gedurende een van de dagen van de week. De units hadden elk een centraal thema dat aansloot op de doelstellingen voor geletterdheid die golden voor het tijdperk waarop het onderzoek in de scholen werd uitgevoerd. Elke unit beoogde twee of drie doelstellingen te realiseren die betrekking hadden op de ontwikkeling van vroege geletterdheid of digitale geletterdheid. Deze doelstellingen leidden tot de hoofdlijn in het verhalen vertellen alsook in de vervolgactiviteiten. Het thema in deze activiteiten was "Ik". Dit is een gebruikelijk thema voor klasse-activiteiten in het begin van het schooljaar. In studie 1 waren er drie sessies (units) in elke conditie. In de studies 2 en 3 omvatte het onderzoek telkens 6 sessies.

Naast de ontwikkeling van de units, zijn er ook tests ontwikkeld die zich richten op de meting van vroege geletterdheid en vroege digitale geletterdheid. The effectiviteit van de verhalende activiteiten op de ontwikkelende geletterdheid werd gemeten in een min of meer natuurlijke context. In totaal werden er twee sets van tests ontwikkeld. De vroege geletterdheidstests (in de studies 1, 2 en 3) richtten zich op de meting van vaardigheden voor lezen en schrijven zoals kennis van het alfabet, herkennen van fonemen, en herkennen van gedrukte tekst. De vroege digitale geletterdheidstests (in de studies 1 en 2) richtten zich op de meting van twee dimensies van digitalisering te weten cognitief (kritisch denken en multimodaliteit) en sociaal-emotioneel (communicatie en sociale vaardigheden). Naast deze zelfontwikkelde tests, werden ook twee gestandaardiseerde tests gebruikt in studie 3 .

\section{STUDIE 1}

In deze studie werd onderzocht of het initiële ontwerp van de twee verhalen vertellende benaderingen, de mondelinge en digitale, leidden tot een verhoging van de geletterdheid van de kinderen in vergelijking met de controle conditie. In dit onderzoek werd ook verkend of er een effect was op de digitale geletterdheid. De belangrijkste resultaten van studie 1 kunnen als volgt worden samengevat. De zelf-ontwikkelde tests voor geletterdheid en digitale geletterdheid bleken betrouwbaar. De kinderen die de reguliere aanpak (de controle conditie) hadden gekregen boekten een kleine voortuitgang op hun geletterdheid. De mondelinge en digitale benadering verhoogden de geletterdheid significant meer dan de controle conditie. De scores in digitale conditie lagen significant hoger dan in de controle en de mondelinge conditie. In alle drie de condities werd een significante verbetering van de digitale geletterdheid gevonden. Op deze tests scoorden de experimentele condities significant en substantieel hoger dan de controle conditie. De beide experimentele condities verschilden op deze tests niet van elkaar. 


\section{STUDIE 2}

In deze studie werd opnieuw onderzocht of de mondelinge en digitale benadering leidden tot een verhoging van de geletterdheid en digitale geletterdheid van de kinderen. De ontwikkeling van deze vaardigheden werd bestudeerd voor de twee experimentele (verhalen vertellende) condities en een controlegroep. De belangrijkste bevindingen van deze studie repliceerden in hoofdlijn de uitkomsten van de eerste studie en breidden deze uit naar een context van zes weken van geletterdheidsactiviteiten. Deze langere duur van de aanpak vertaalde zich in een grotere ontwikkeling van vaardigheden vergeleken met de eerste studie. In alle drie de condities werd een significante en substantiële vooruitgang gemeten voor geletterdheid. De twee experimentele condities ontwikkelden zich significant beter dan de controle conditie, maar tussen deze condities werd geen significant verschil gevonden. Net zoals in de eerste studie bleken de digitale vaardigheden zich aanzienlijk te verbeteren. Deze ontwikkeling was echter alleen significant in de experimentele condities die onderling niet verschilden.

\section{STUDIE 3}

In deze studie werd opnieuw de effectiviteit gemeten van een 6-weken durende interventie voor de verbetering van de geletterdheid. De ontwikkeling van de digitale vaardigheid werd in deze studie niet gemeten. De opzet was verder dezelfde als die van de tweede studie, met dien verstande dat de resultaten werden aangevuld met metingen van gestandaardiseerde tests voor geletterdheid. Bij de kinderen werden voor aanvang van het onderzoek de zelf-ontwikkelde tests afgenomen alsmede de gestandaardiseerde DIBELS en GRTR test. De bevindingen op de zelfontwikkelde tests repliceerden in grote lijn de uitkomsten voor geletterdheid van de tweede studie. In alle drie de condities verbeterde de geletterdheid, en in de twee experimentele condities was dat significant en substantieel meer dan in de controle conditie. De scores op de gestandaardiseerde tests lieten ook significante en substantiële verbeteringen zien in alle drie de condities. In de digitale benadering waren de effecten het grootst, maar onderling verschilden de condities niet van elkaar op de gestandaardiseerde tests.

\section{Conclusie}

De drie empirische studies in deze dissertatie lieten zien dat een gestructureerde verhalen vertellende benadering effectiever is in de bevordering van geletterdheid en digitale geletterdheid dan een benadering met een meer conventionele aanpak. Verhalen vertellen is een natuurlijke wijze van onderwijzen en leren die kinderen motiveert en, indien gecombineerd met spel-achtige vervolgactiviteiten, leidt tot actieve deelname en goede leerresultaten. Deze dissertatie geeft in grote lijn ondersteuning aan de bewering dat een gestructureerde benadering waarin verhalen vertellende activiteiten zijn vervlochten kan leiden tot activiteiten die tegelijk bijdragen aan de ontwikkeling van geletterdheid en digitale geletterdheid van de kinderen. 

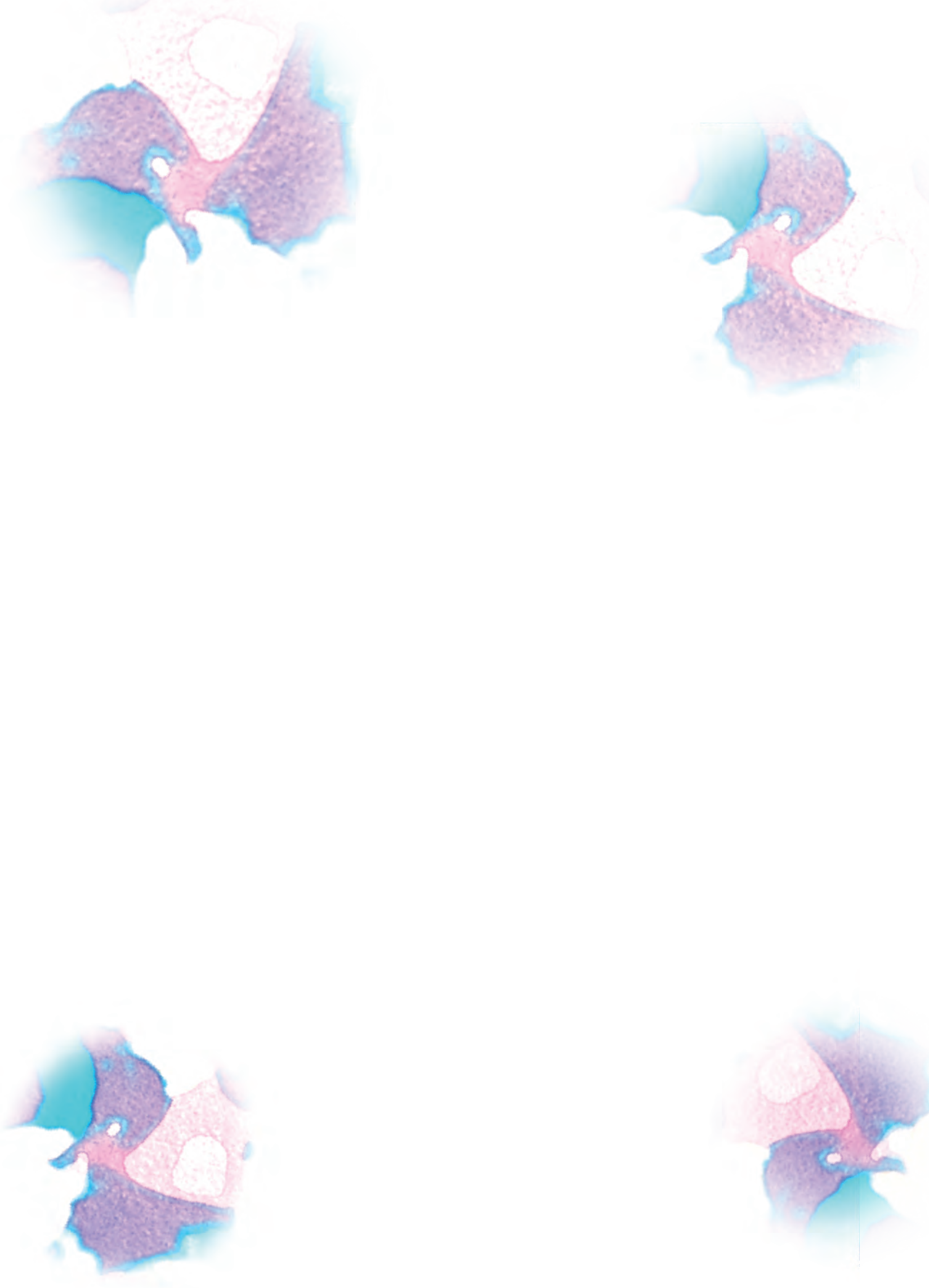

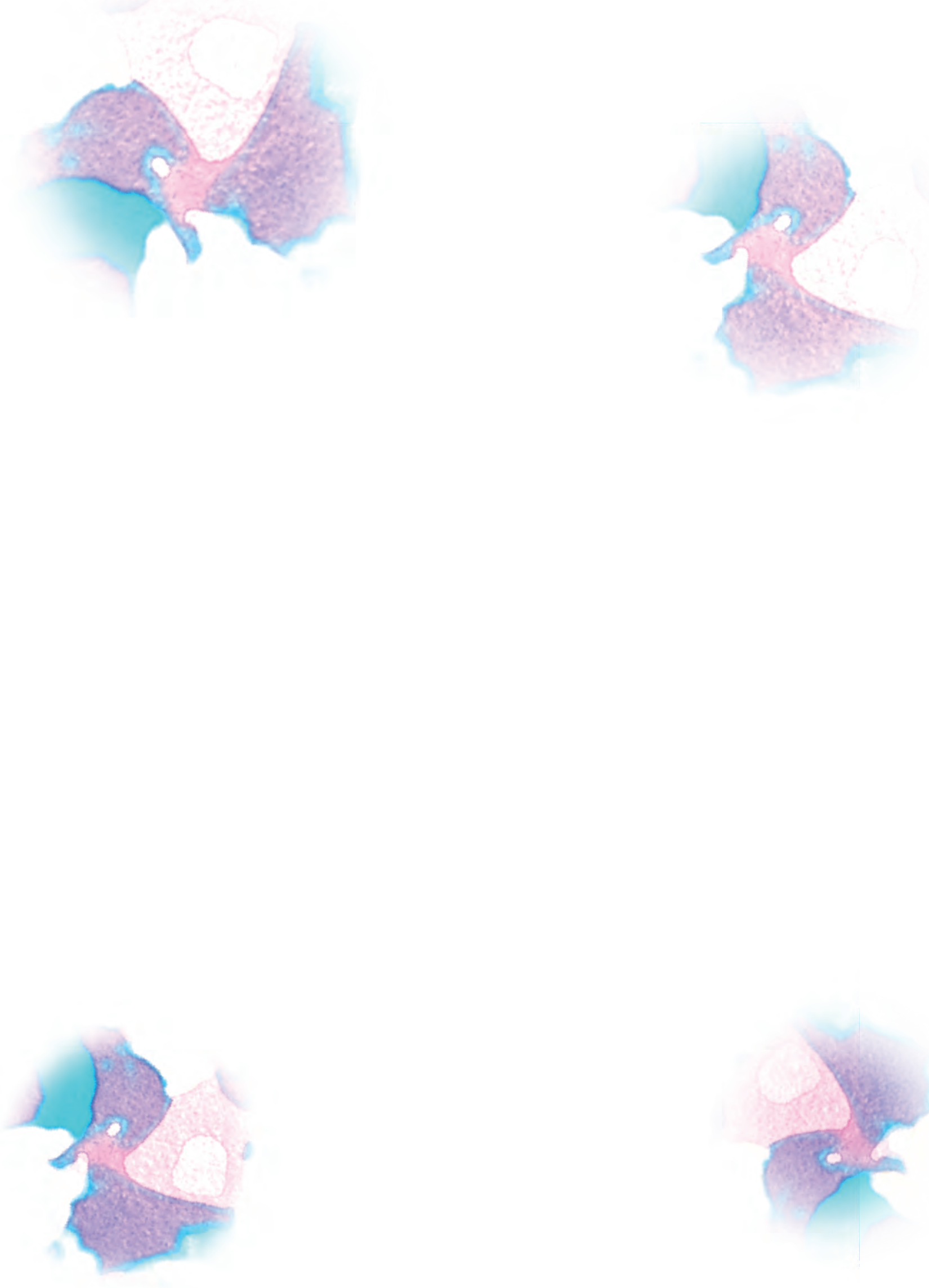